\title{
البحث التناسع:
}

العلاقة بين السلامهة النفسية للبيسئة التعليسمية والصحة النفسية للطنلاب الصنية

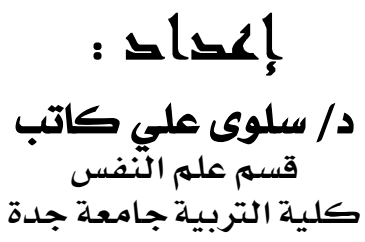





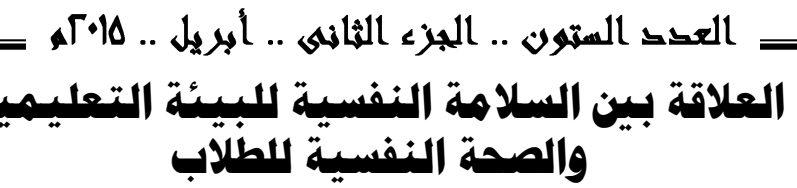

د/ سلوى علبي كاتب

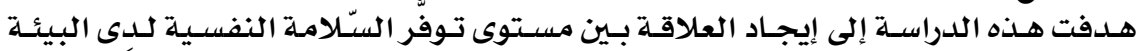

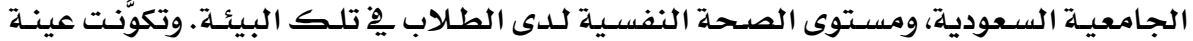

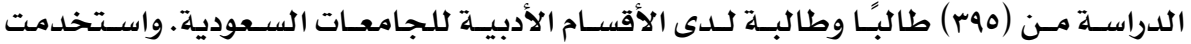

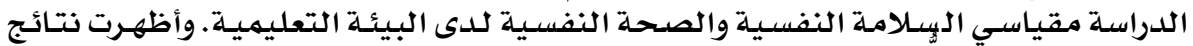

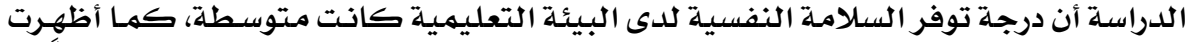

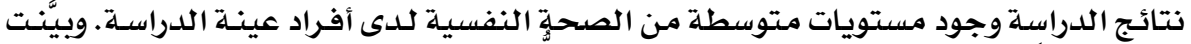

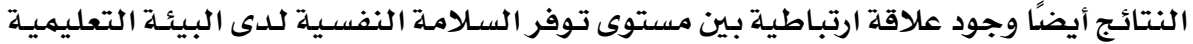

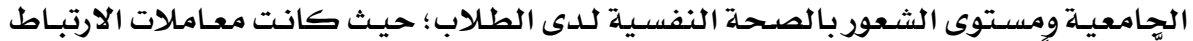

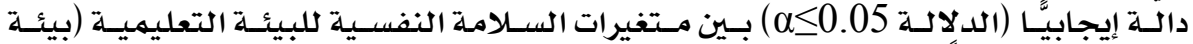

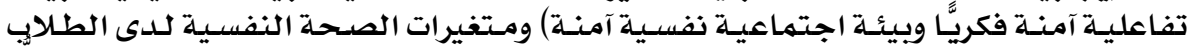

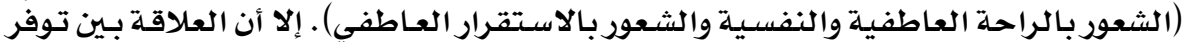

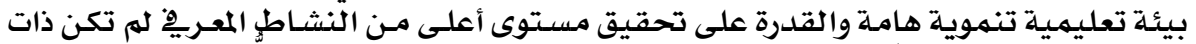

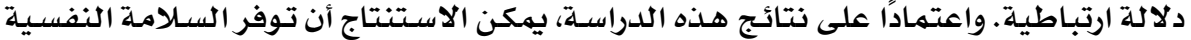

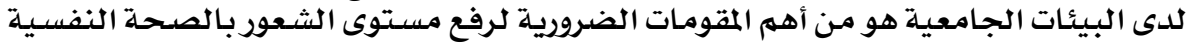

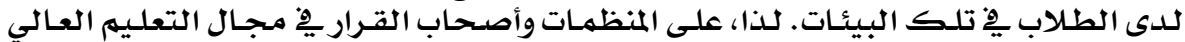

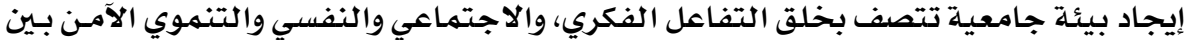

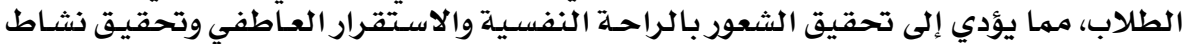

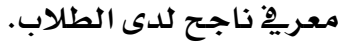

الكلمات المفتاحية: السلامة النفسية، البيئة التعليمية، الصححة النفسية، البيئة الجامعية،

The Psychological Safety of the Educational Environment and Psychological Health of Students

\section{Dr. Salwa Ali Kateb}

\section{Abstract:}

This paper investigates the relationship between the psychological safety factors of university educational environment and the development of psychological health of university students in Saudi Arabia. The study sample consisted of (395) male and female students from Jeddah University and King Abdulaziz University, Faculties of Education, Arts and Humanities. A questionnaire was designed to collect the necessary data using psychological safety scale (composed of three factors, 12 statements), and psychological health scale (composed of three factors, 15 statements). The results showed that the psychological safety level within the Saudi educational environment and the psychological health of university students were moderate. The findings also showed significant positive relationship 


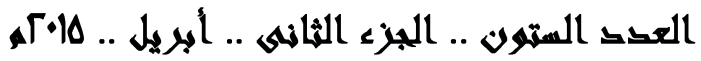

between the psychological safety factors of educational environment (free of psychological violence for interaction and free of sociopsychological violence) and the psychological health factors of students (emotional and psychological comfort and psychological stability). No significance relationship between the developmental factor of the educational environment and the levels of having cognitive abilities and achievements was found. The study concludes that making a psychologically safe educational environment is a critical key to improve

the psychological health of university students. Universities and decision makers in the domain are advised to psychologically improve their educational environment to be free of psychological and sociopsychological violence for proper interaction and cognitive developments.

Keywords: Psychological Safety, Educational Environment, Psychological Health, University Environment, Psycological Violance.

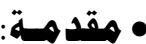

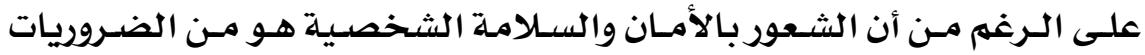

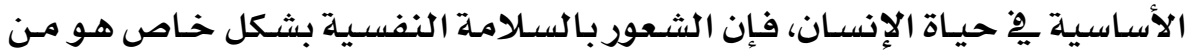

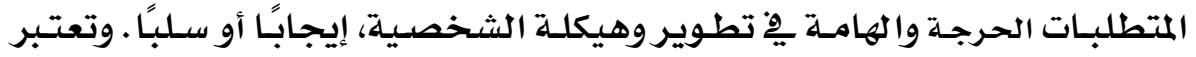

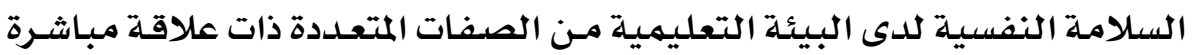

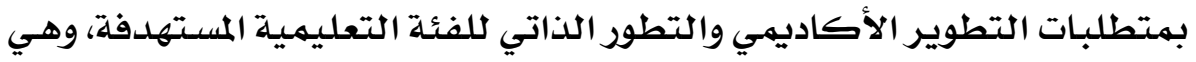

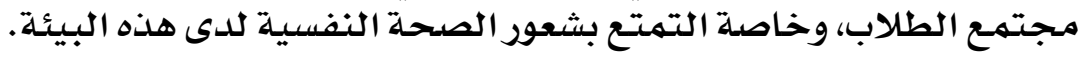

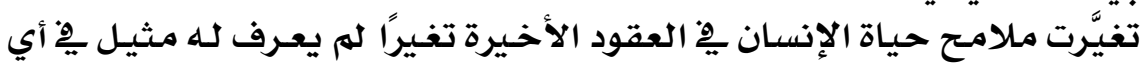

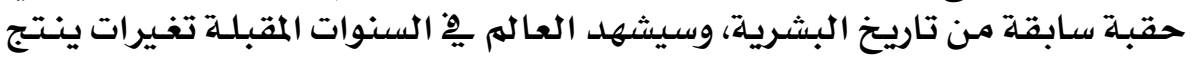

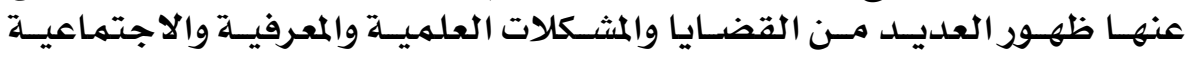

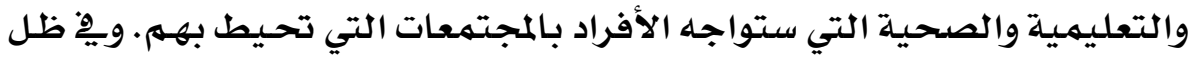

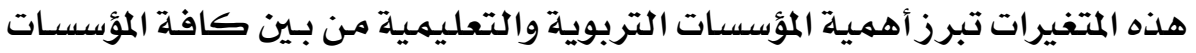

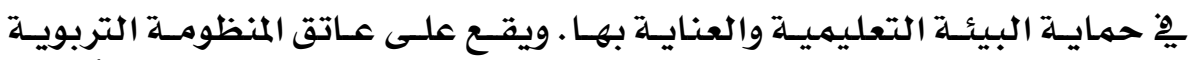

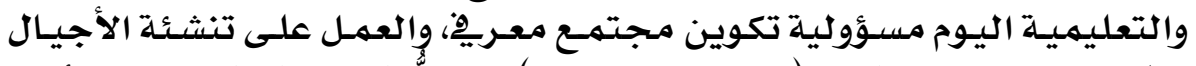

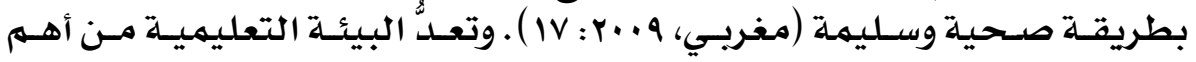

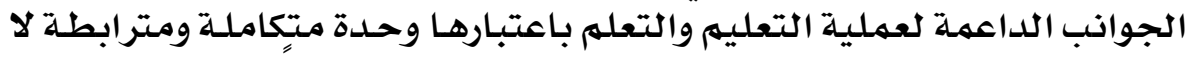

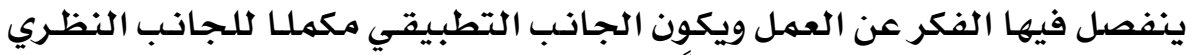

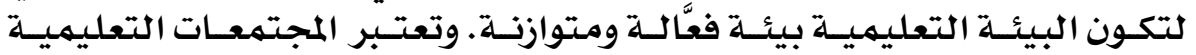

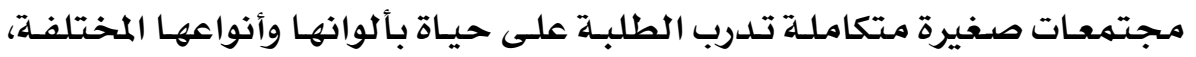




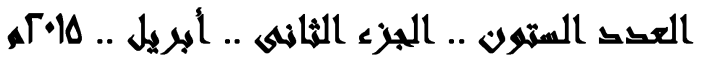

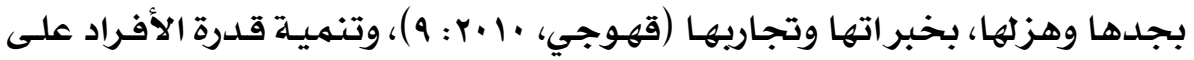

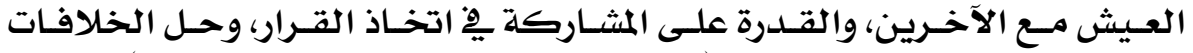
بالنقاش دون اللجوء الى العنف (109: Kovrov and Antonova, 2013 (

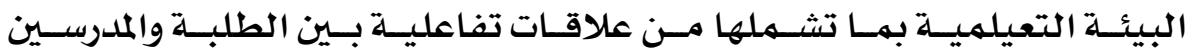

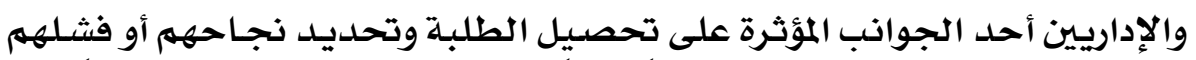

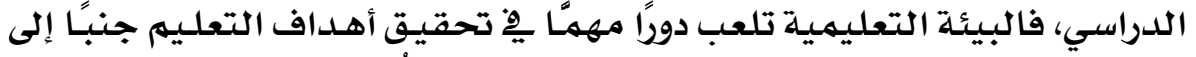

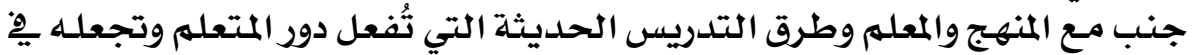

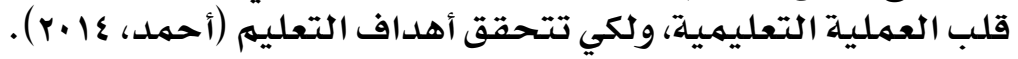

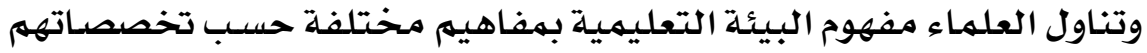

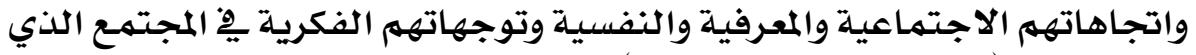

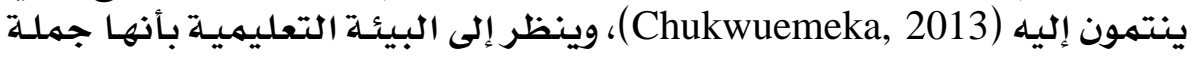
الظروف المادية والتدريسية التي تحيط بـالعمليـة التعليميـة، والتي تشهمل تصسميهم

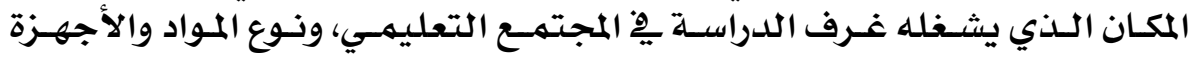

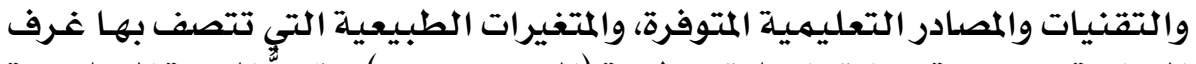

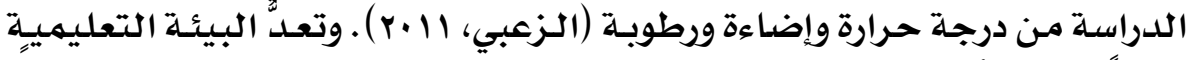

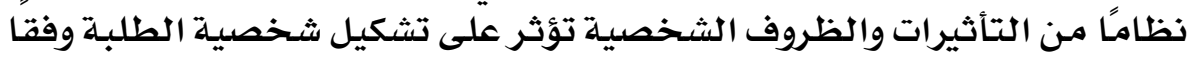

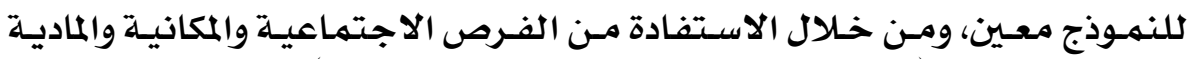

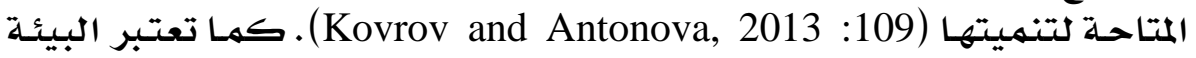

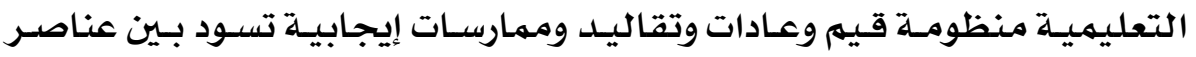

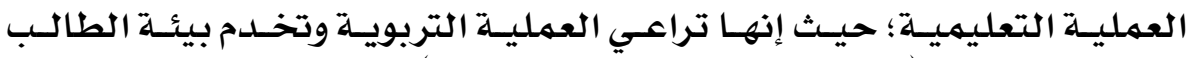

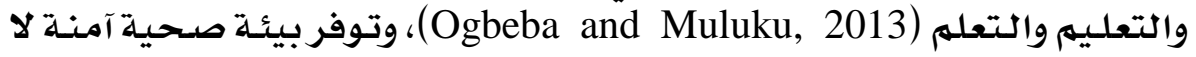
يحسـ فيهـا الطلبــة بـالخوف أو القلـق أو التـوتر أو التهلديــات أو العنـف النفسيسي

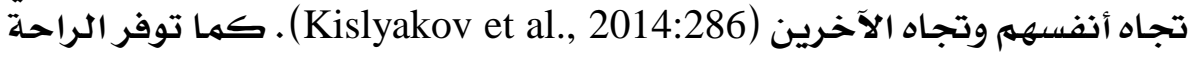

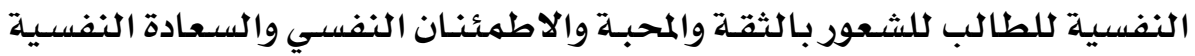

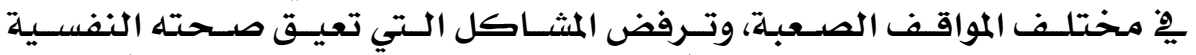
والتهلديدات الخارجيـة والداخليـة (Baeva and Bordovskaia, 2015:89).

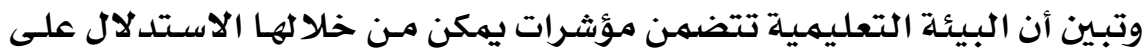

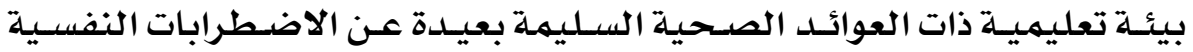
والعنف النفسي.ووأشار كيسليكوف وآخرون (Kislyakov et al., 2014:286) إلى (تلى

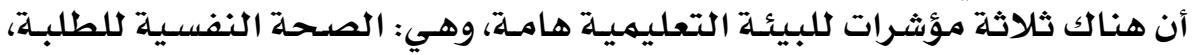

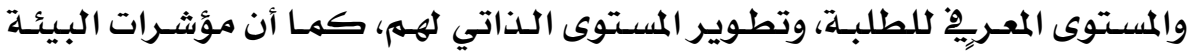

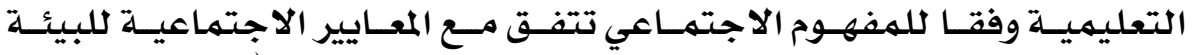

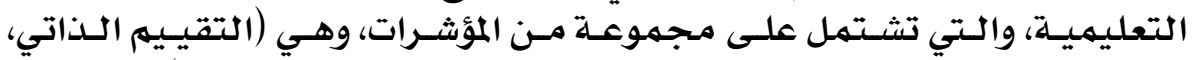

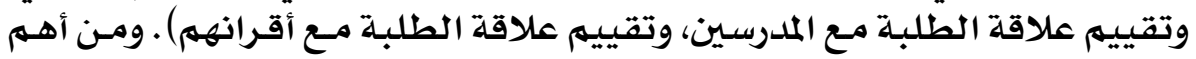


العست الستهو .. الجزء الثمانهى .. أبريل ..

أهداف البيئة التعليهيـة تحسين المخرجات التعليهية من خـلال تجويـد العمليـات

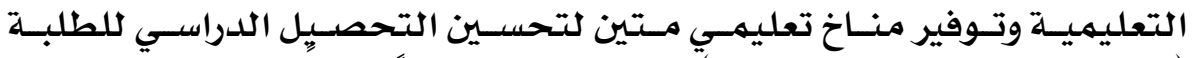

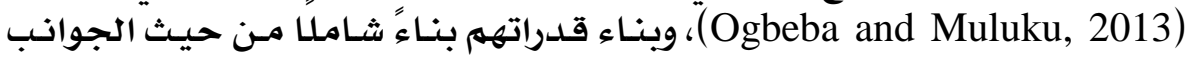
Odeh, ) العقليـة الوجدانيـة والمهاريـة والسـلوكية وتنهيـة اتجـاهـاتهم الإيجابيـة

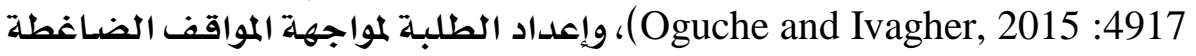

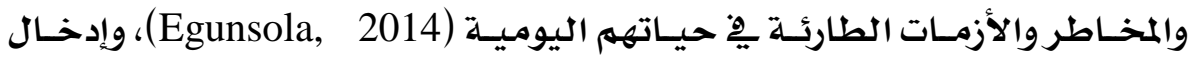

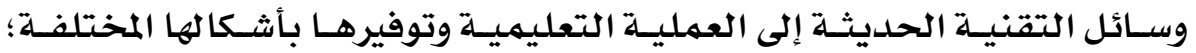

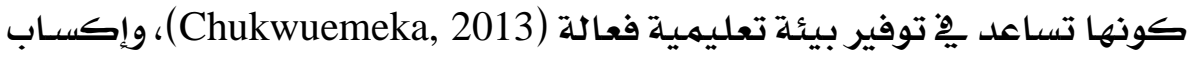

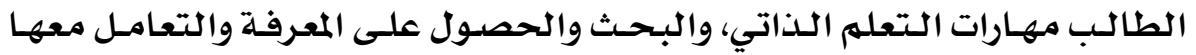

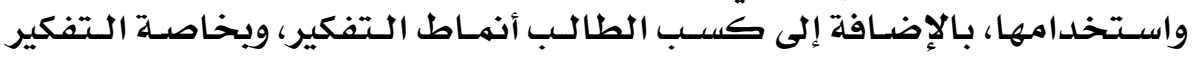

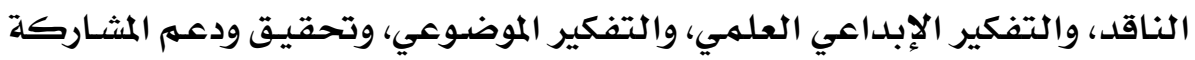

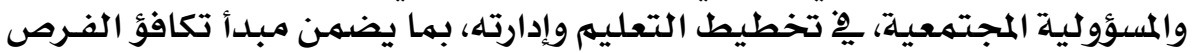

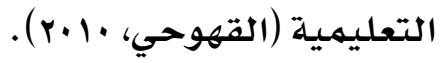

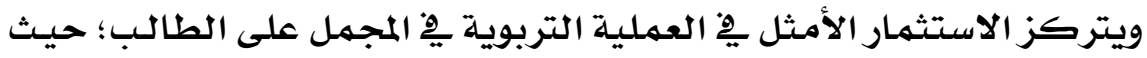
يهثل الهدف الأسهى الذي تدور حوله كافة البر امـج السـاعيـة إلى إعداده بصورة

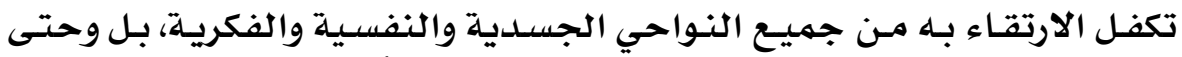

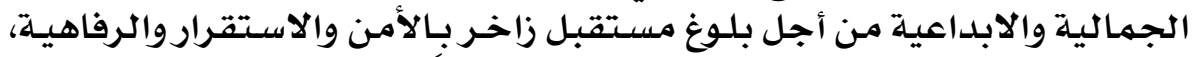

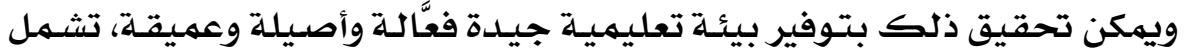

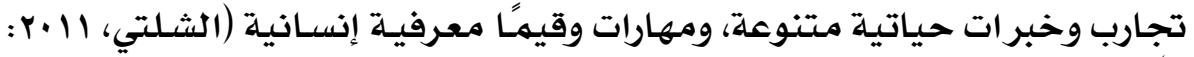

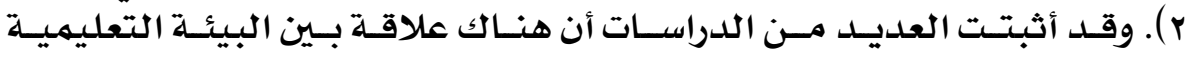

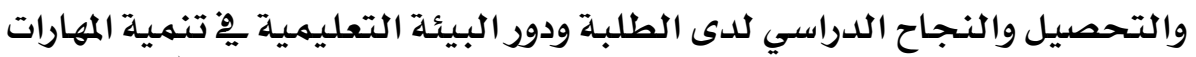

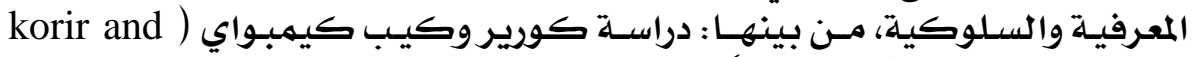

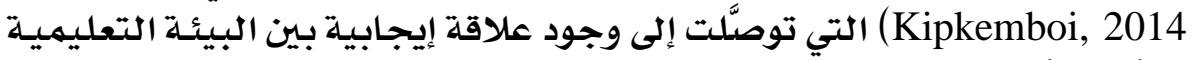

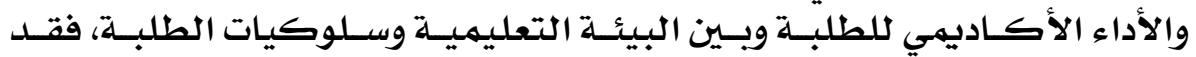

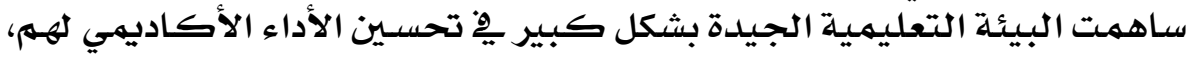

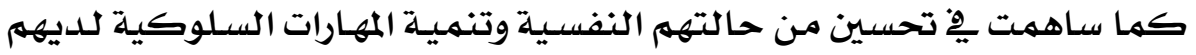

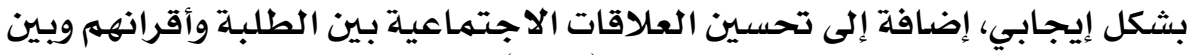

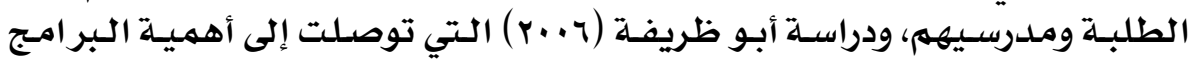

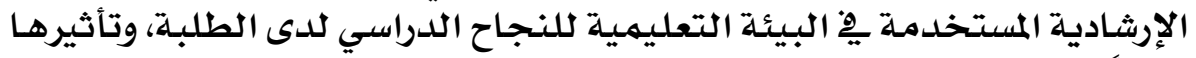
إيجابًا على التحصديل الميل الدراسي.

أمـا آوغبيبـا مليلكو (Ogbeba and Muluku, 2013) فقـد قامـا بـراسـة حـول

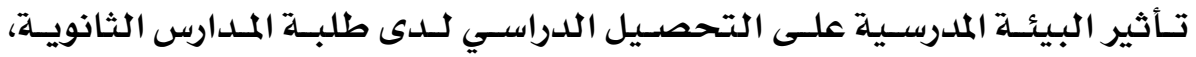

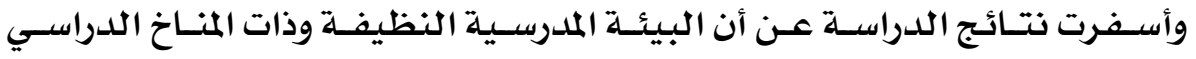

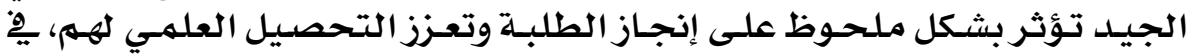


العقى الستهو .. الجزء الثلانهى .. أبريل ..

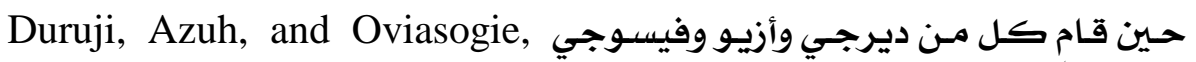

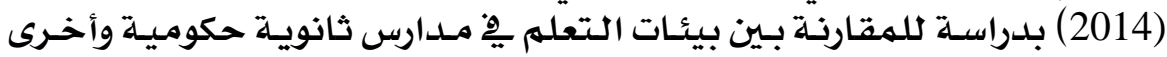

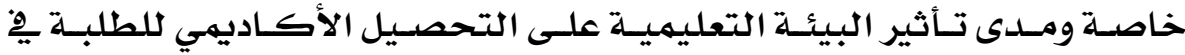

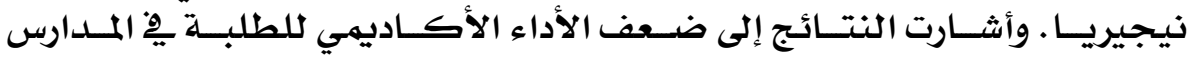

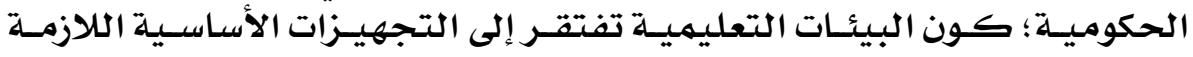

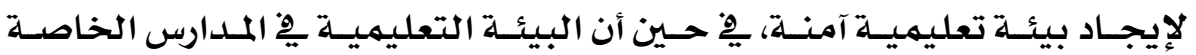

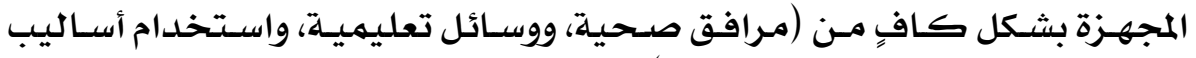

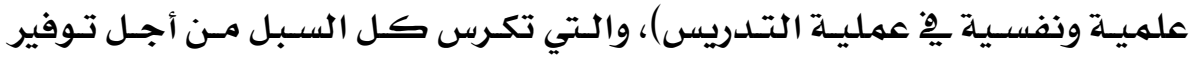

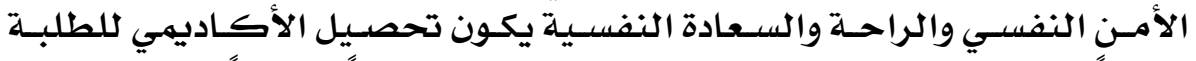

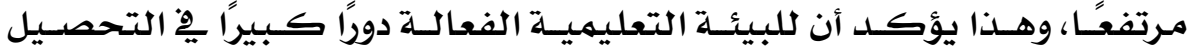

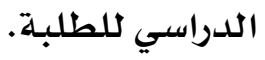

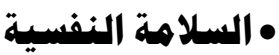

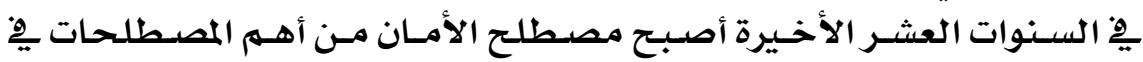

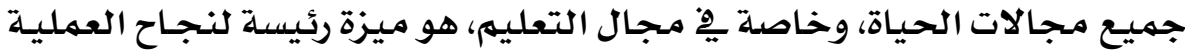

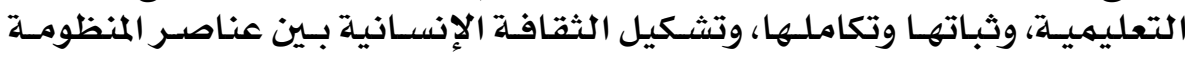

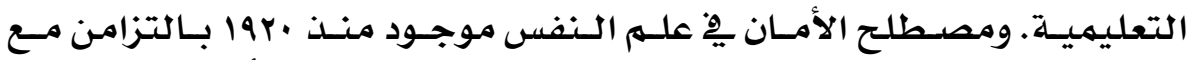

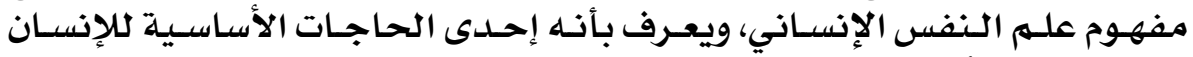

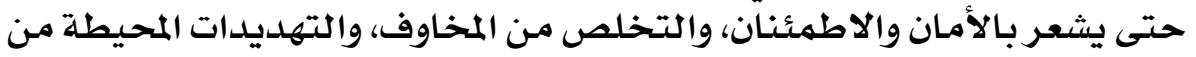

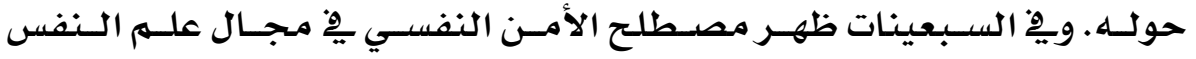

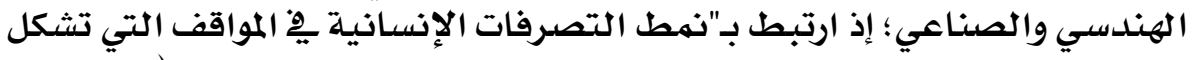

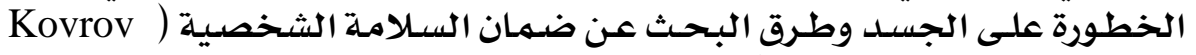
.(and Antonova, 2013 :108

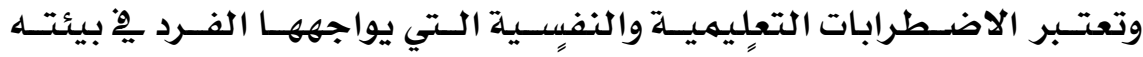

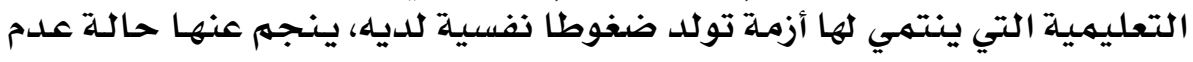

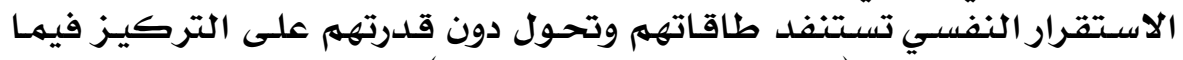

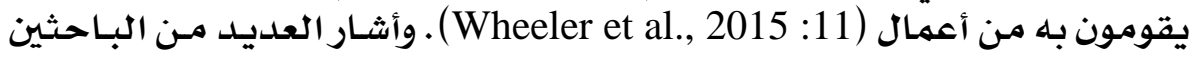

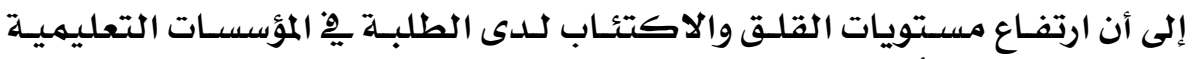

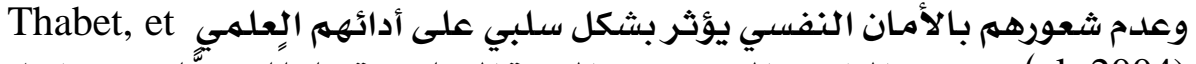

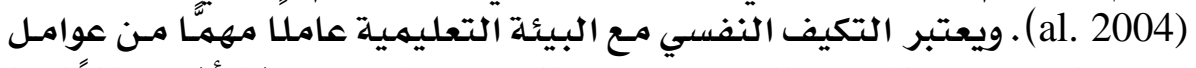

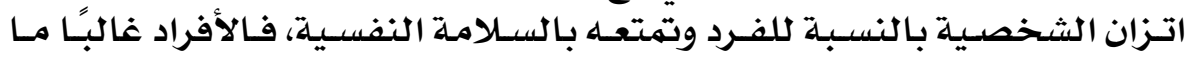

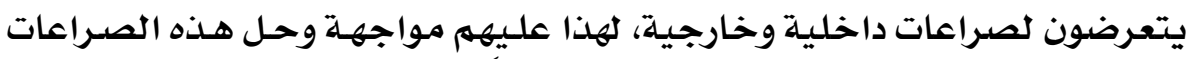

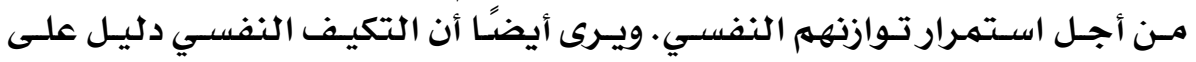

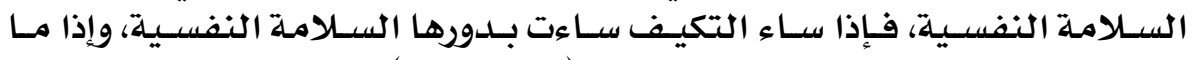

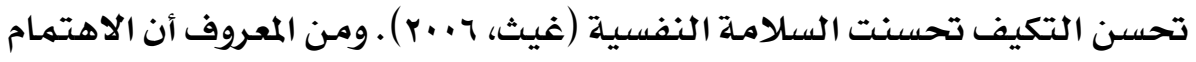




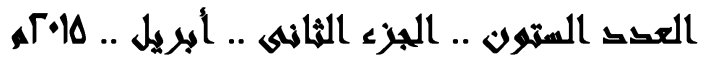

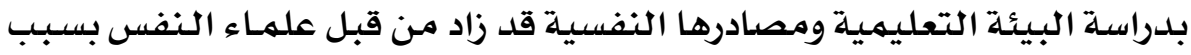

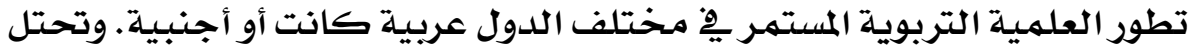

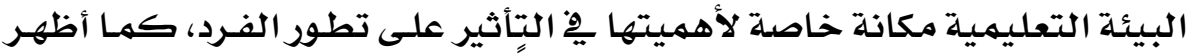

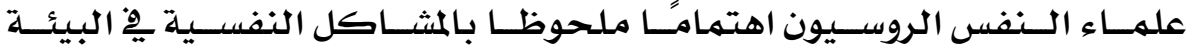

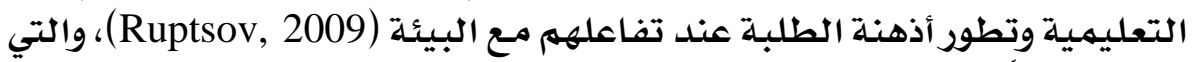

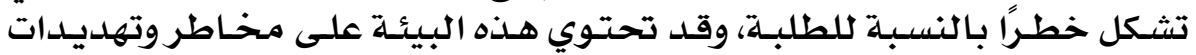

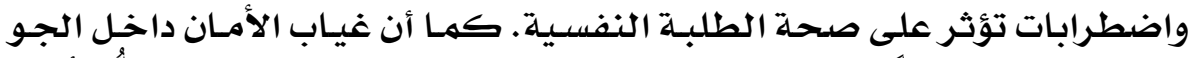

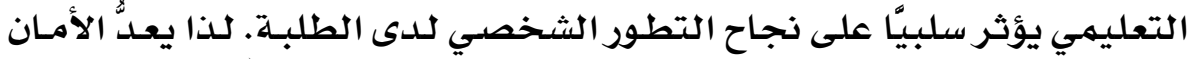

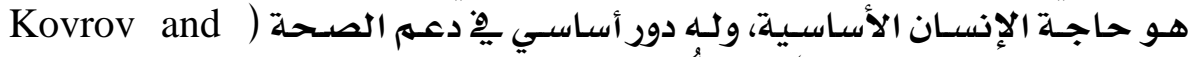

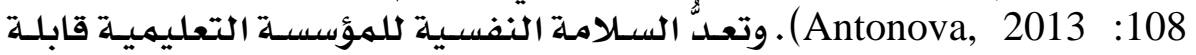

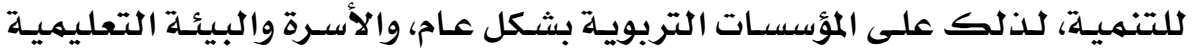

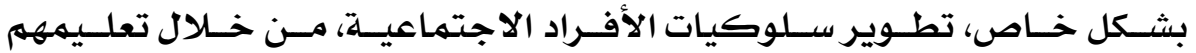

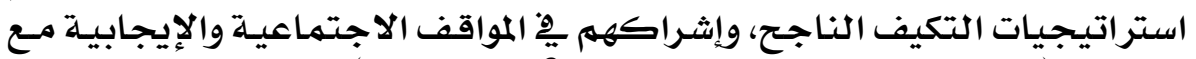

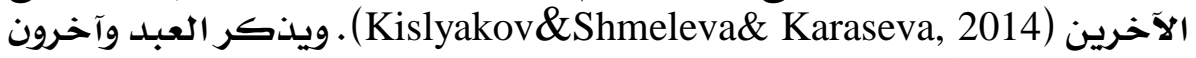

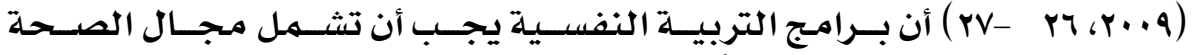

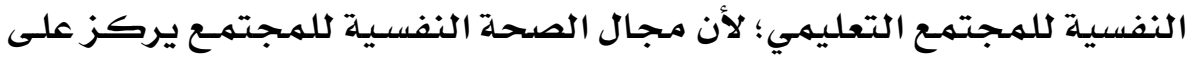

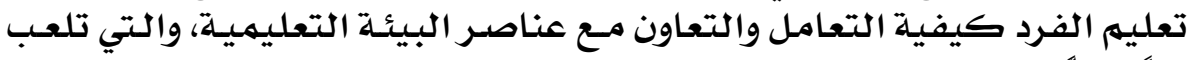

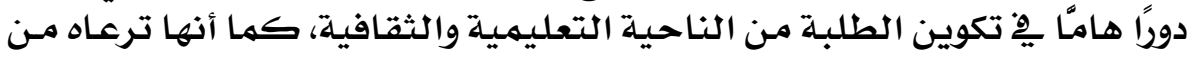

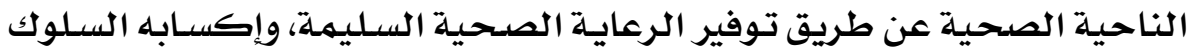

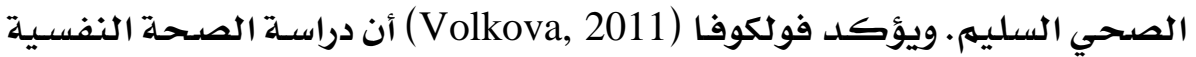

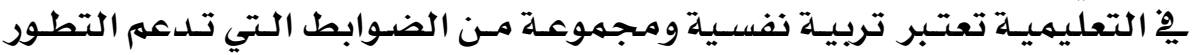

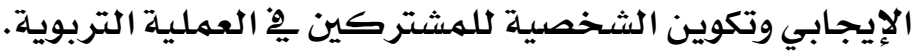

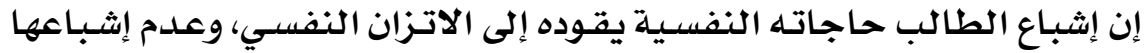

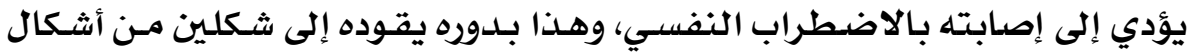

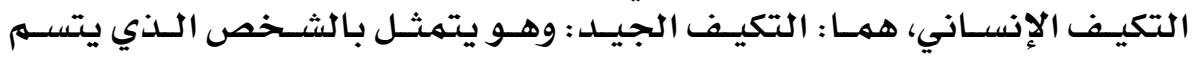

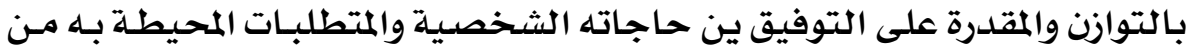

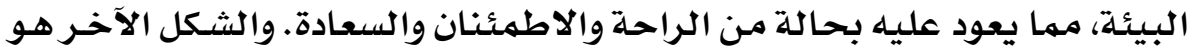

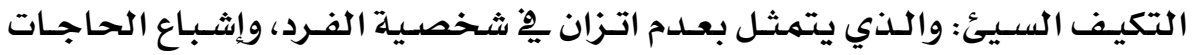

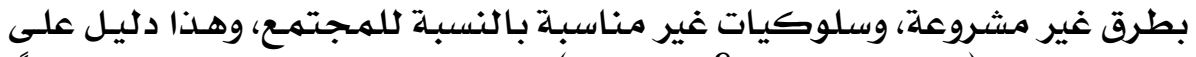

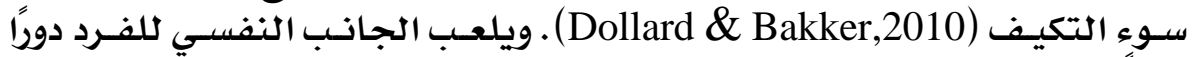

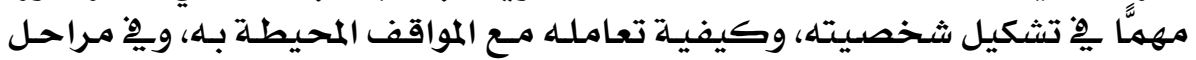

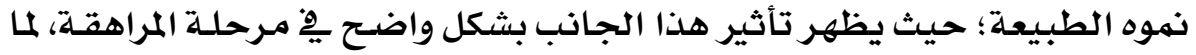

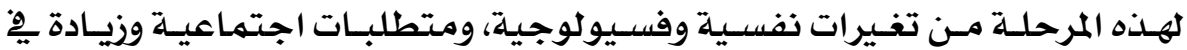




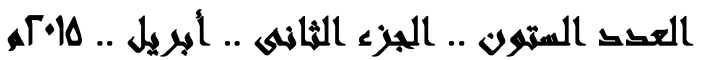

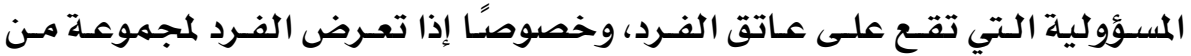
الظروف التي تقع خارج إرادته والتي تقف فِ سير حياته بشكلها الطبيعي.

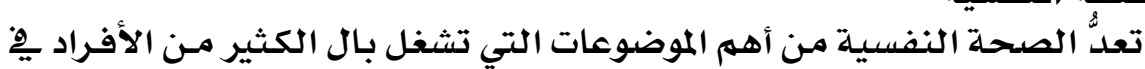

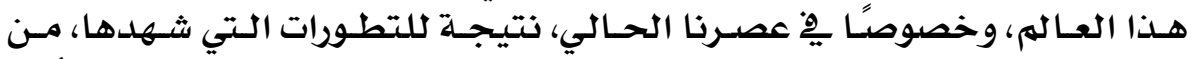

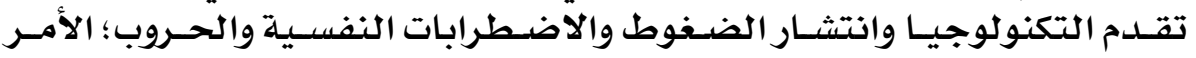

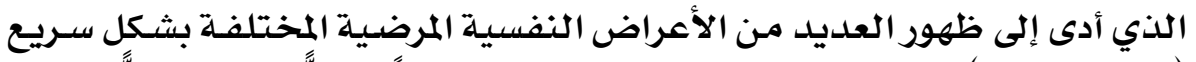

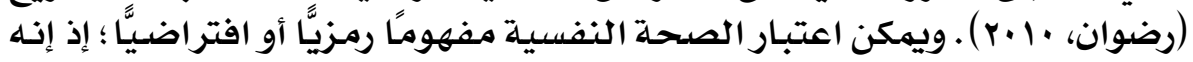

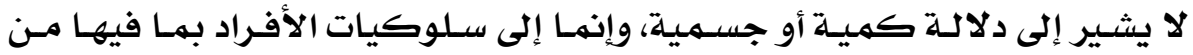

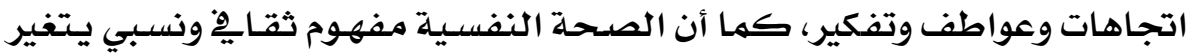

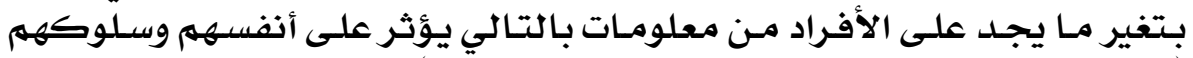
(Verrocchio, Ambrosini, and Fulcheri, 2013)

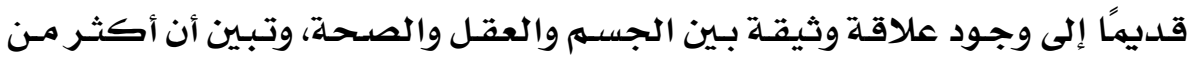

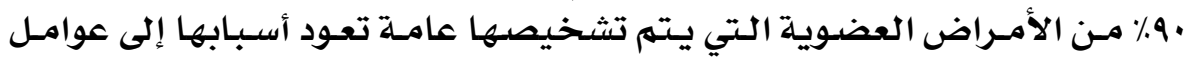

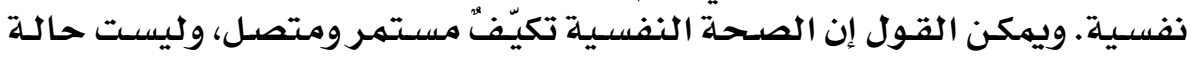

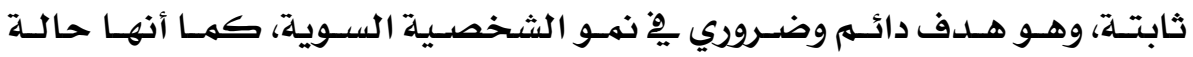

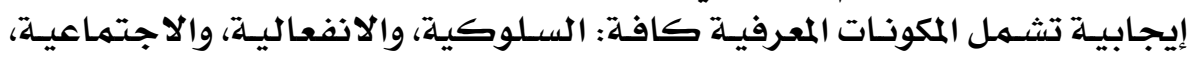

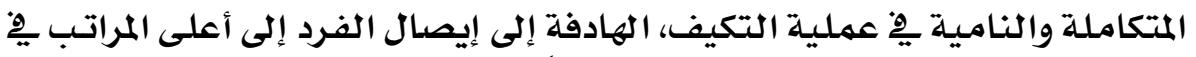

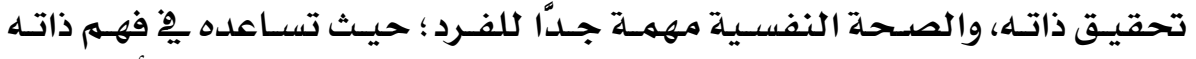

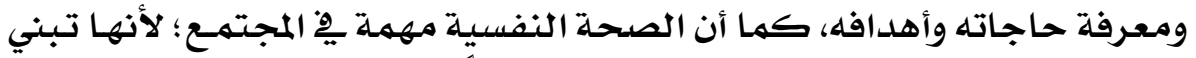

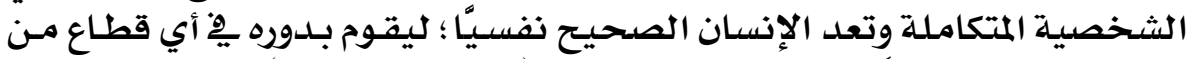
قطاعات المجتمع، وأيًا كان دوره الاجتماعي (أبو العيون، 10 ـr ).

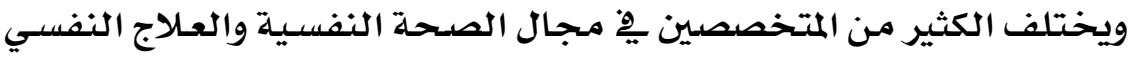

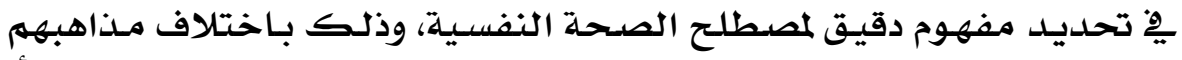

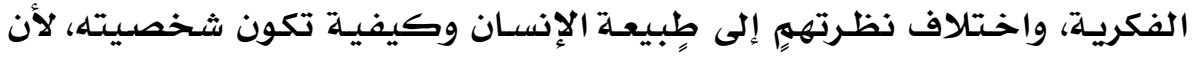

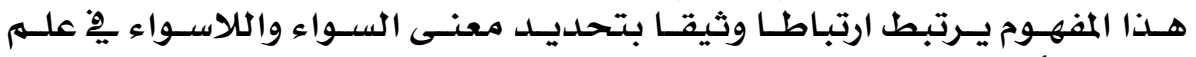

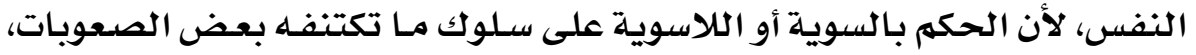

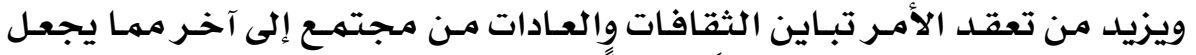

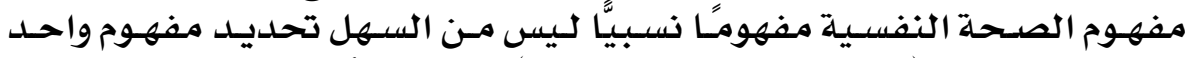

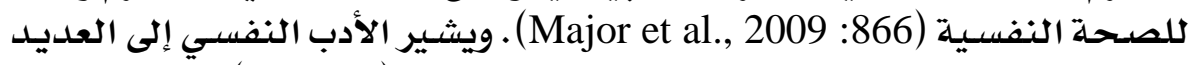

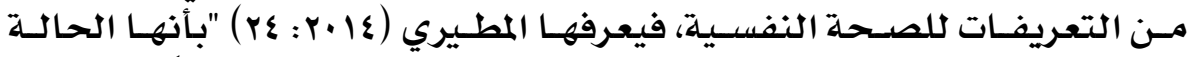

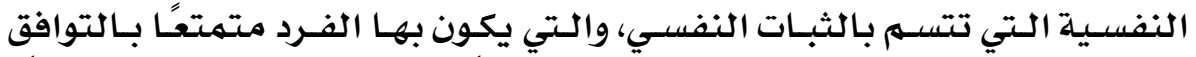

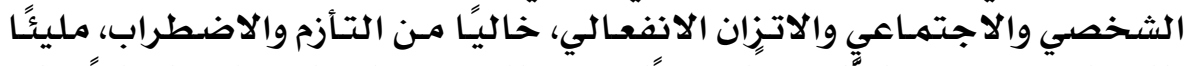

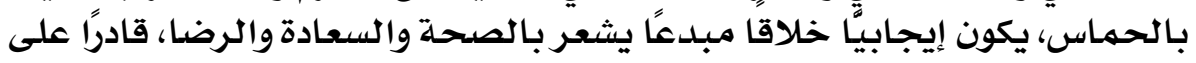




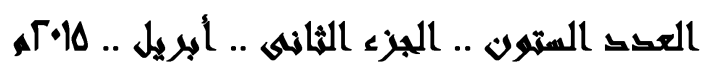

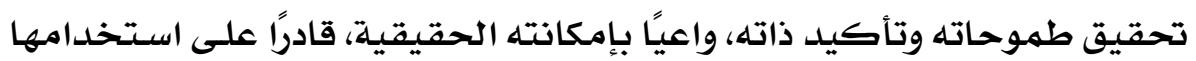

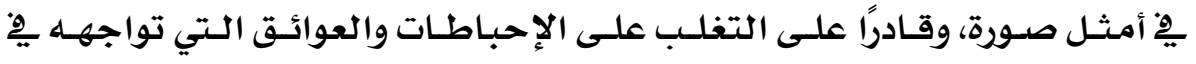

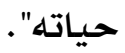

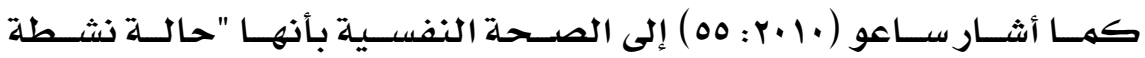

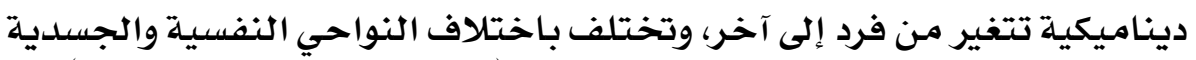

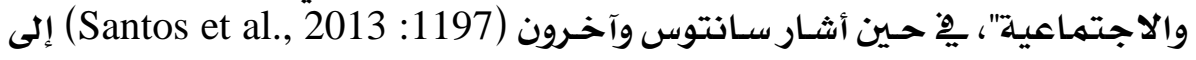

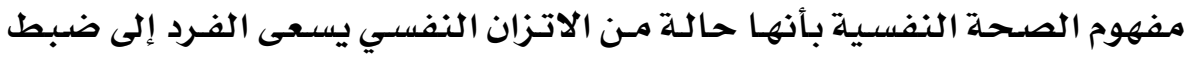

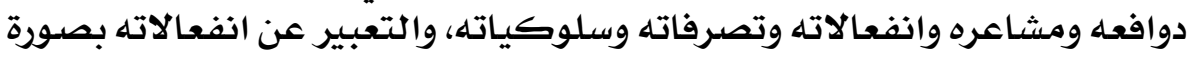

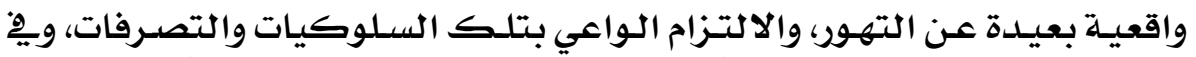

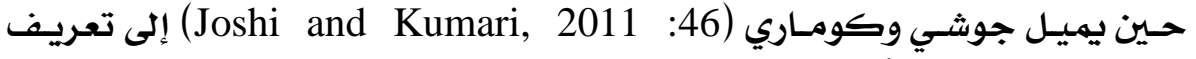

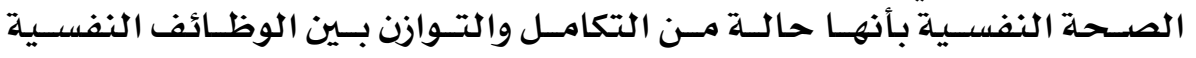

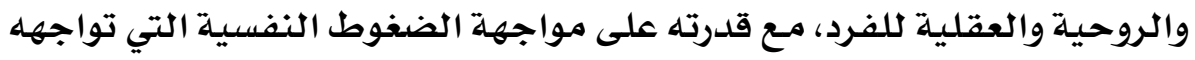

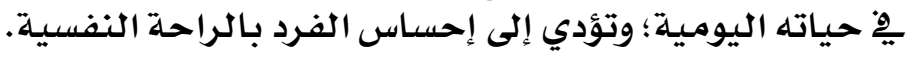

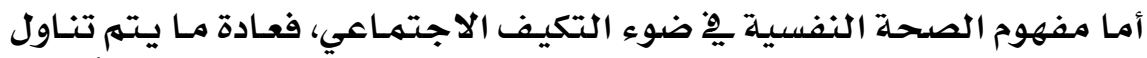

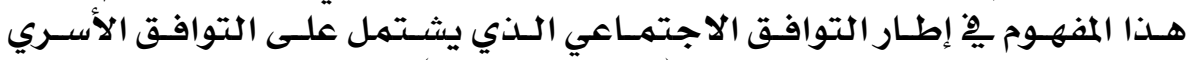

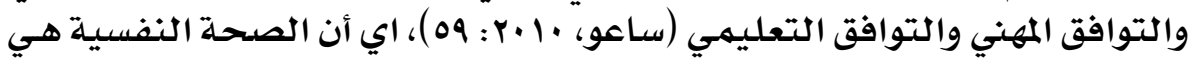

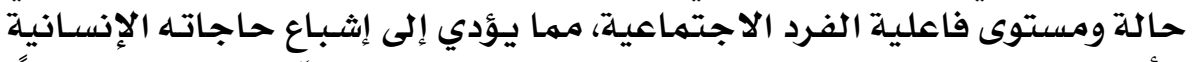

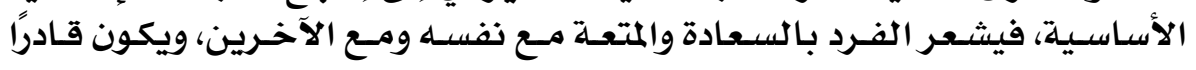

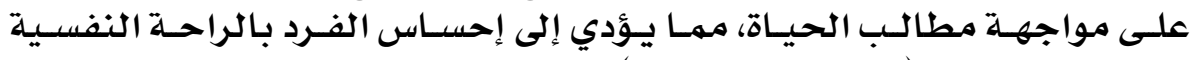

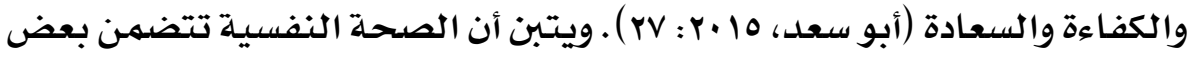

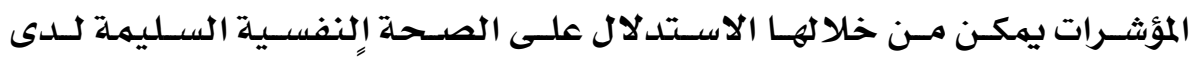

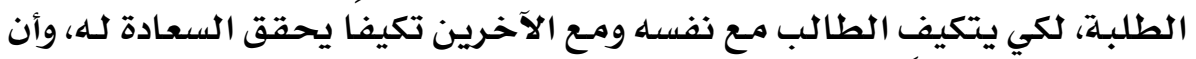

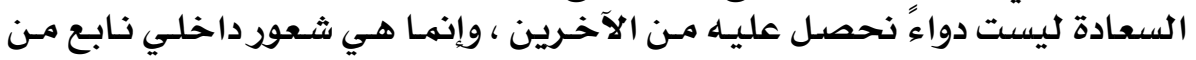

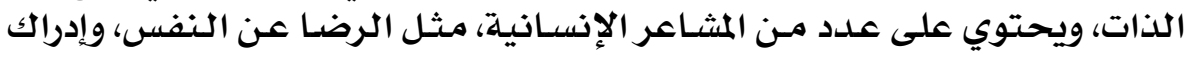

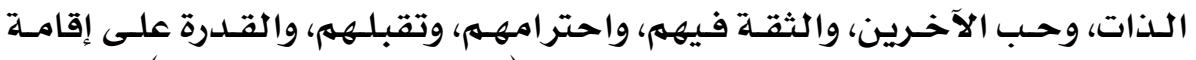

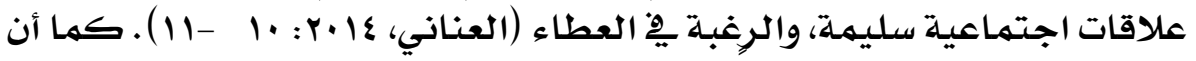

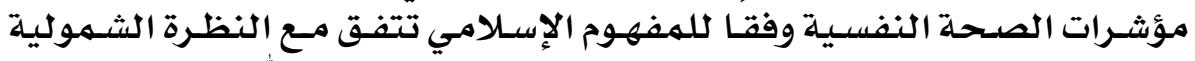

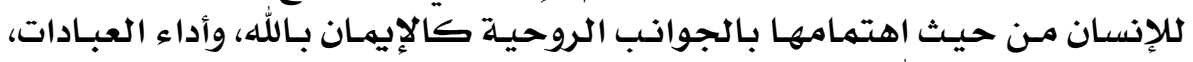

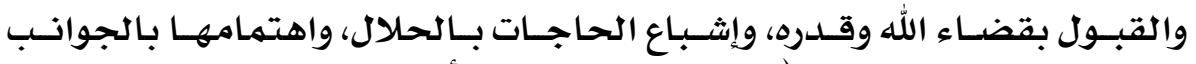

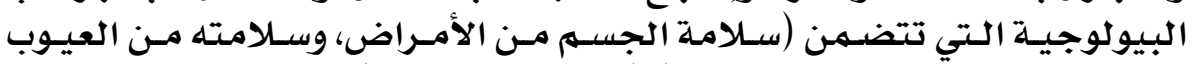
الخلقية، والعناية الصحية بالجسم) (Fisher, 2011:15).

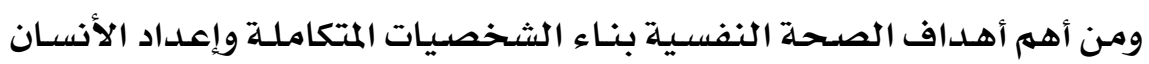

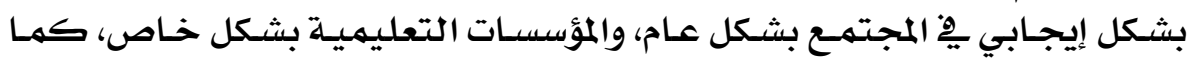




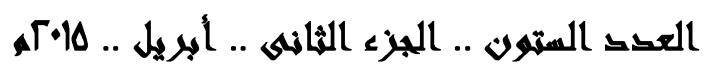

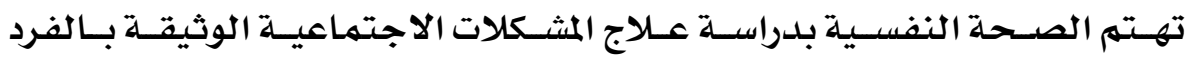

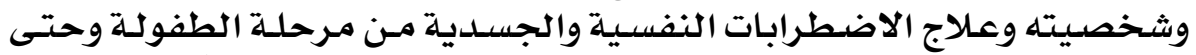

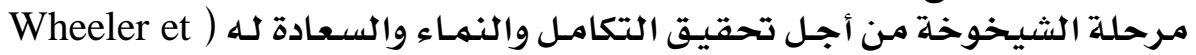

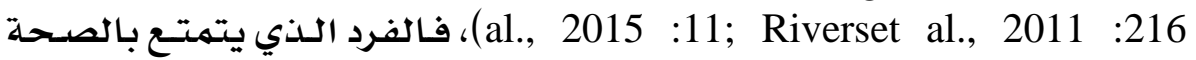

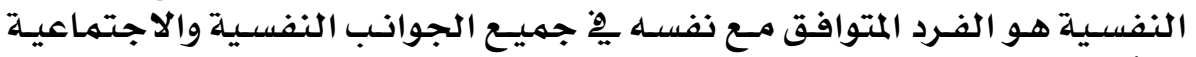

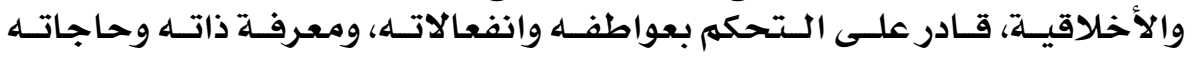

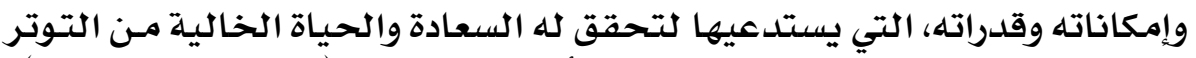

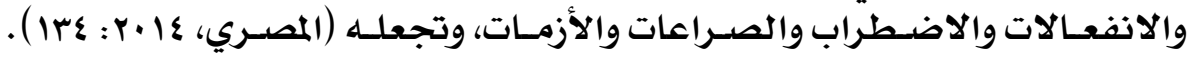

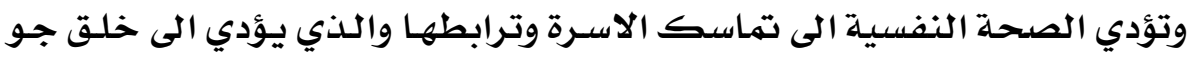

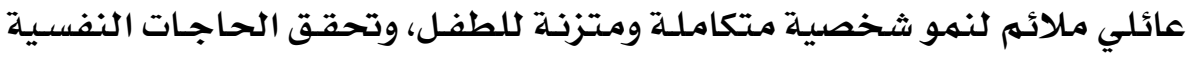

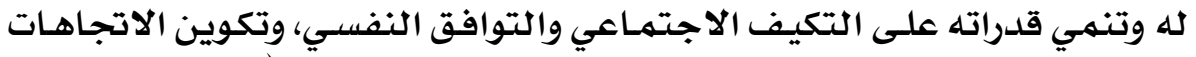

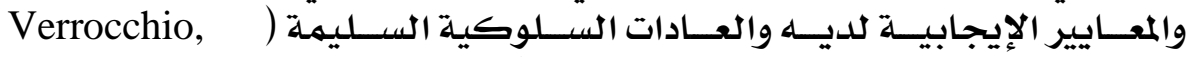
(Ambrosini and Fulcheri, 2013 :406-407

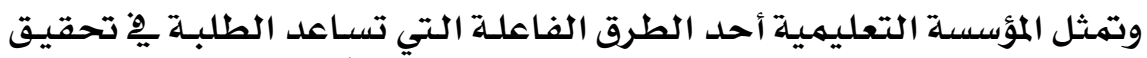

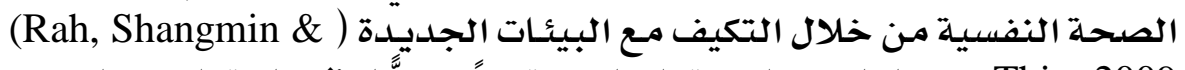

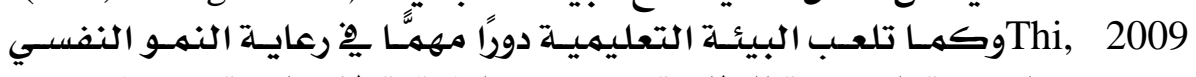

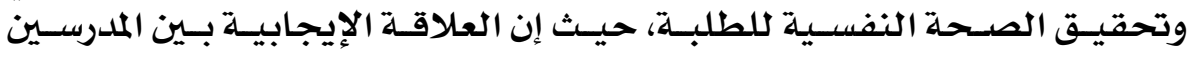

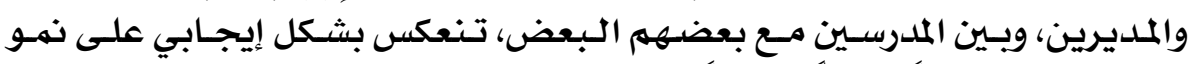

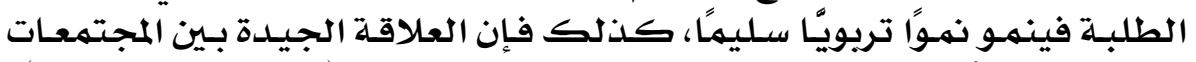

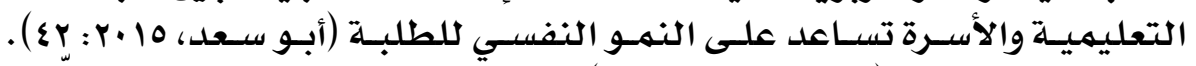

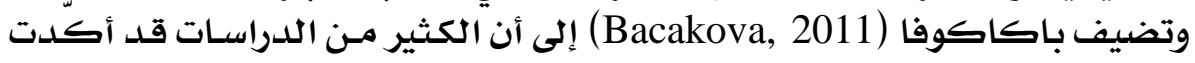

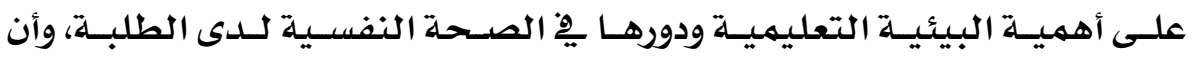

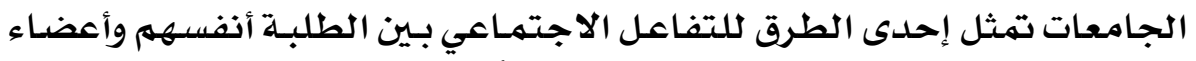

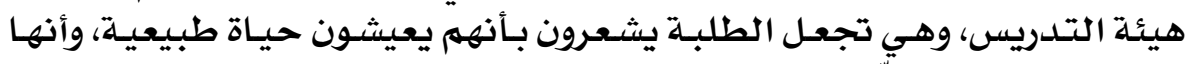

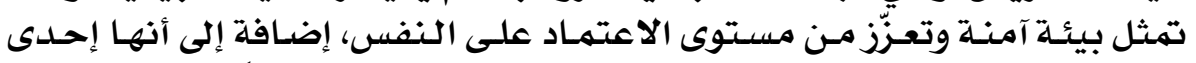

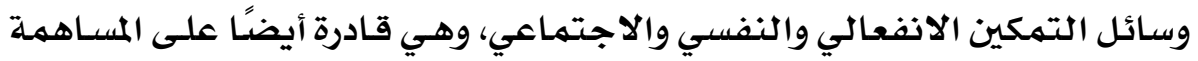

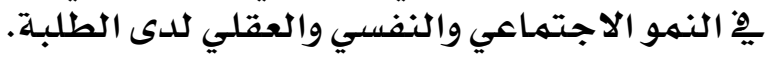

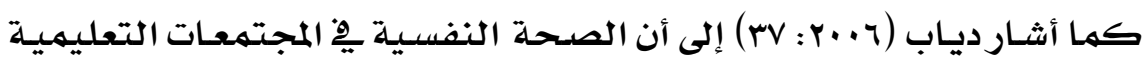

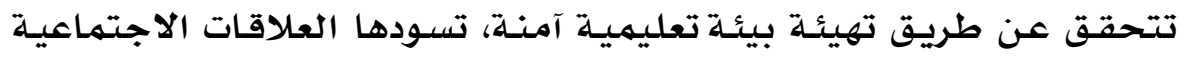

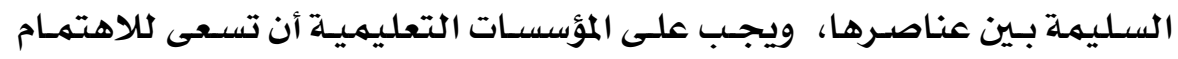

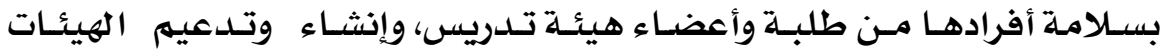

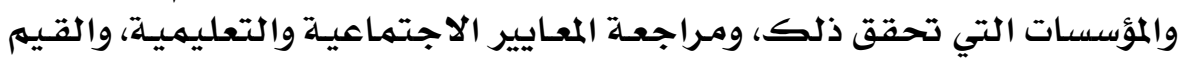

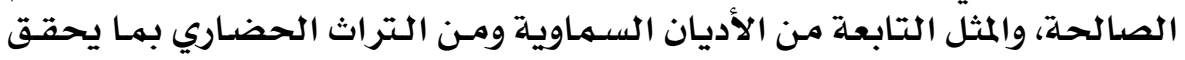

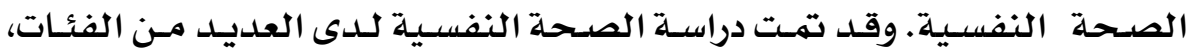




\section{العقى المتهون .. البزء الثخانهى .. أبريل .. هاءمه.}

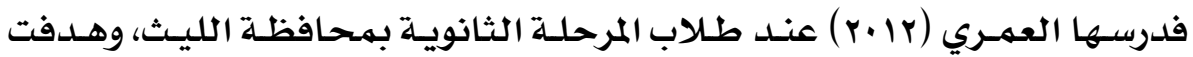

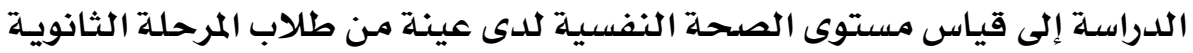

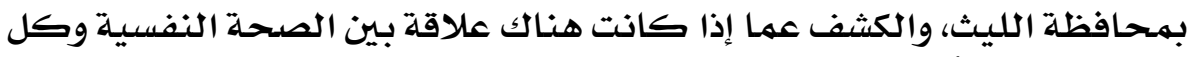

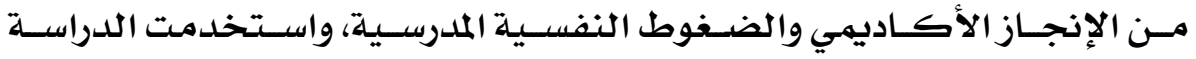

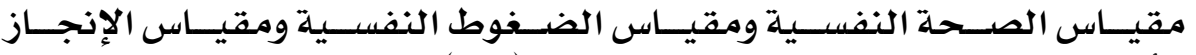

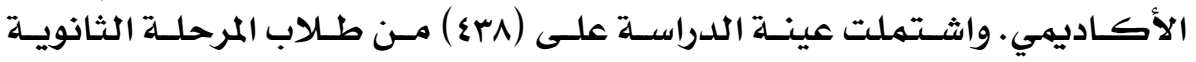

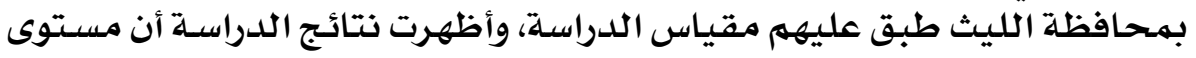

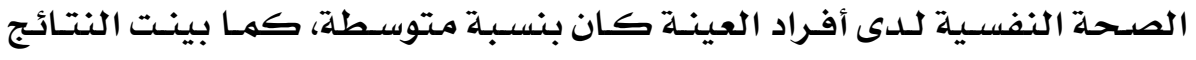

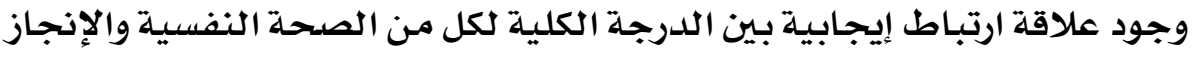

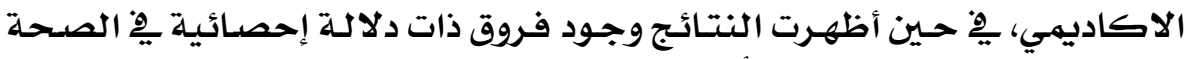

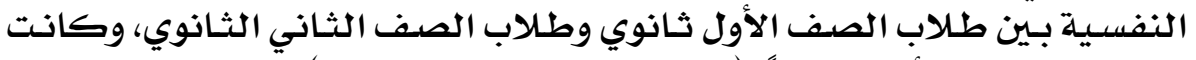
الفروق للطلاب الأكبر عمراً (طلاب الصف الثانين الثاني الثانوي).

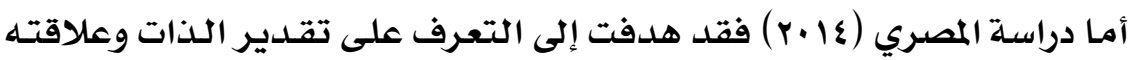

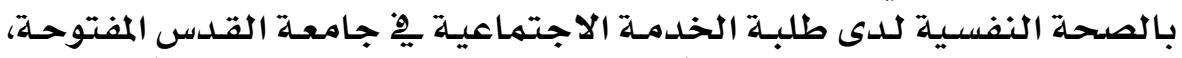

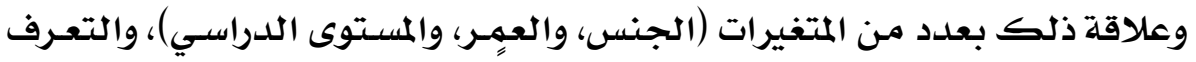

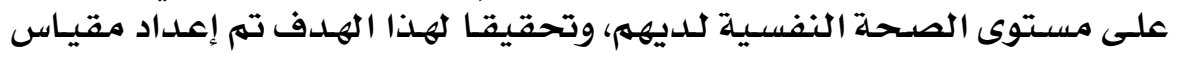

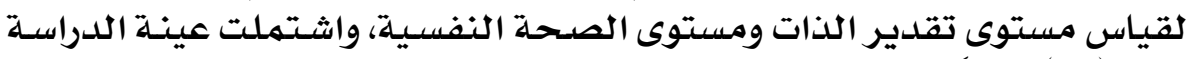

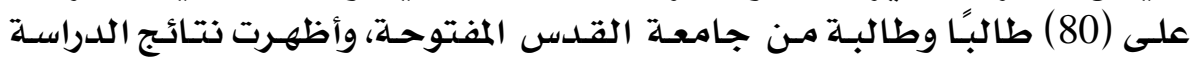

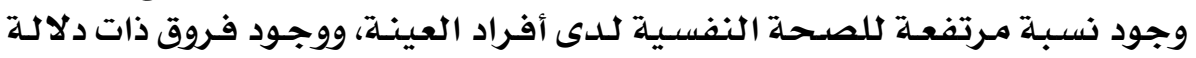

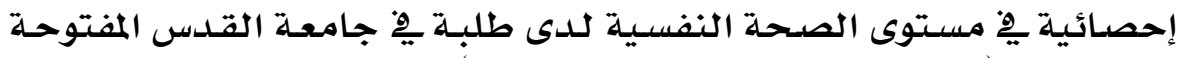

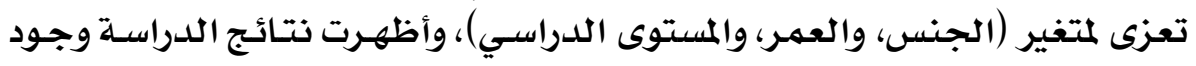

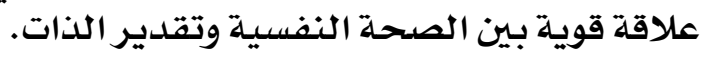

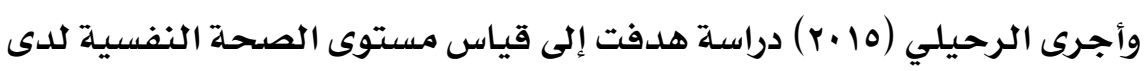

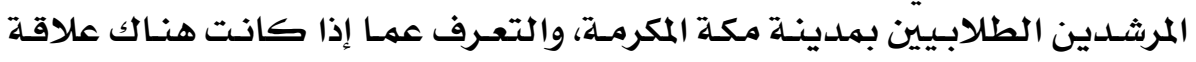

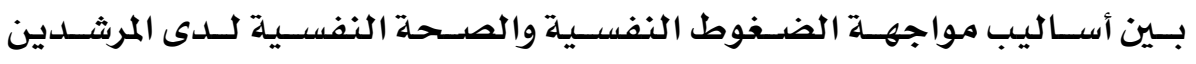

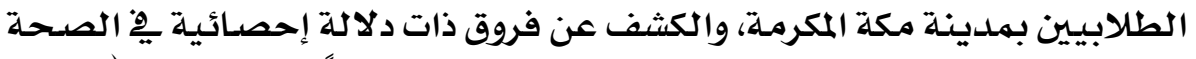

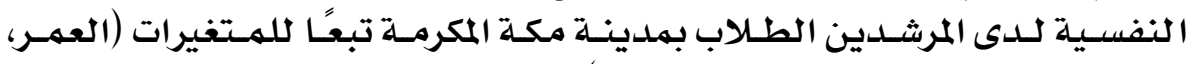

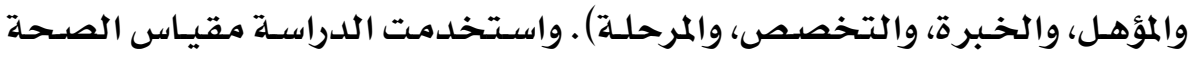

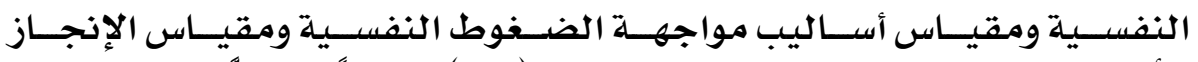

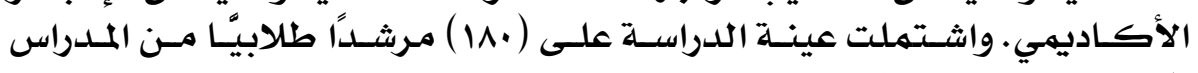

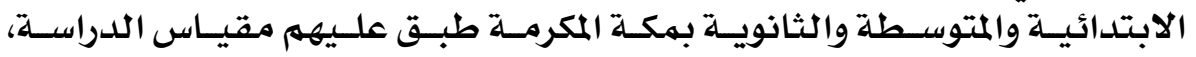

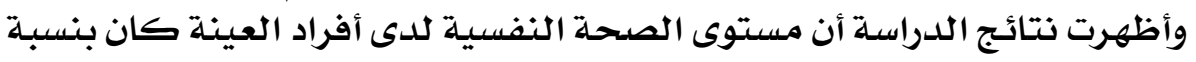

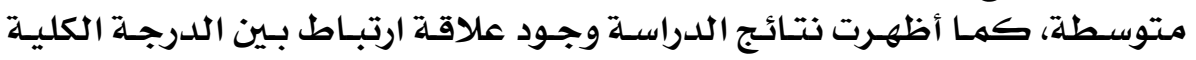

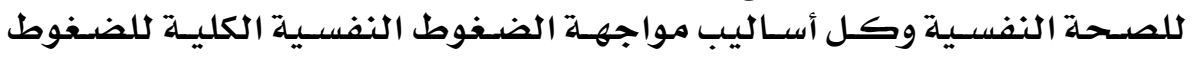

\section{ry $Y$}




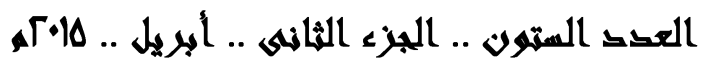

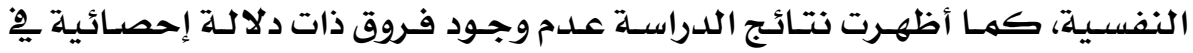

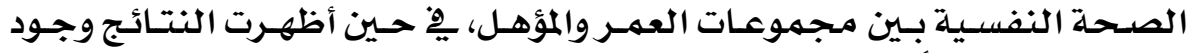

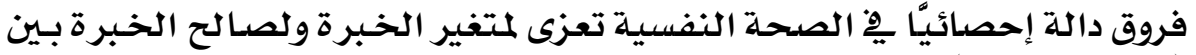

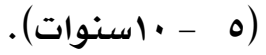

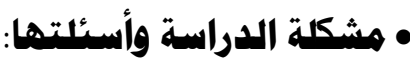

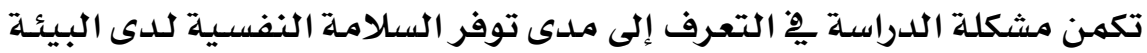

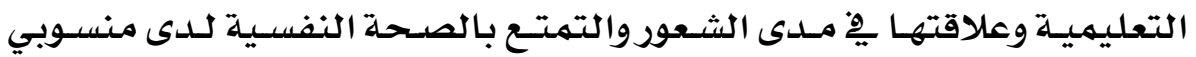

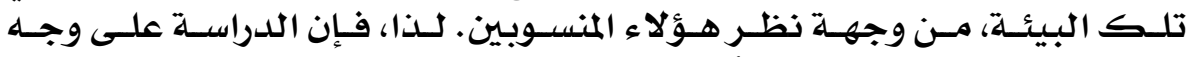

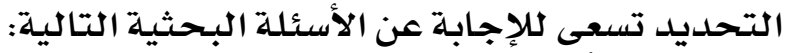

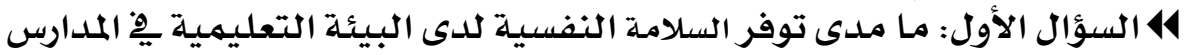

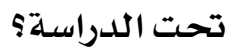

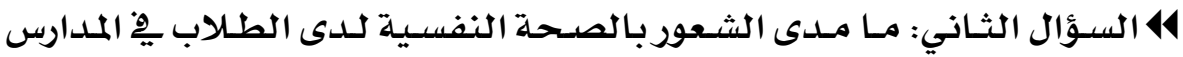

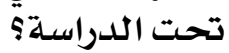

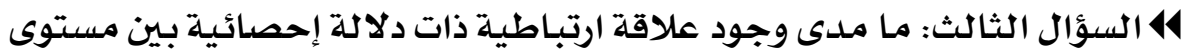

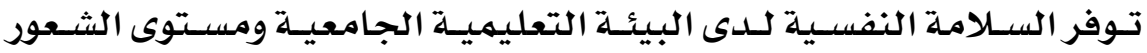

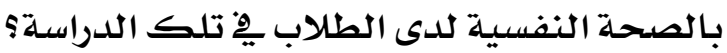

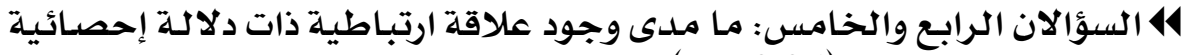

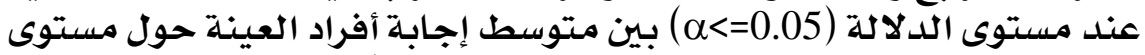

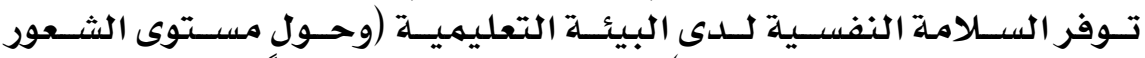

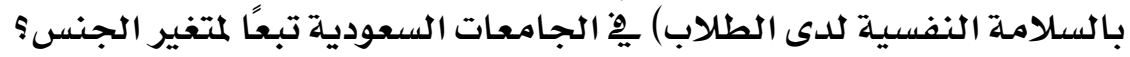
• أهداف الدوراسة:

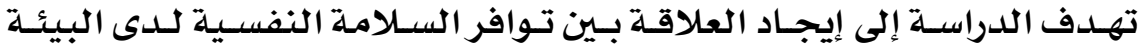

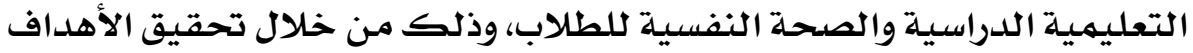
الفرعية التالية:

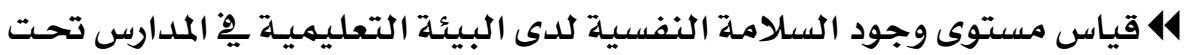
الدراسـة.

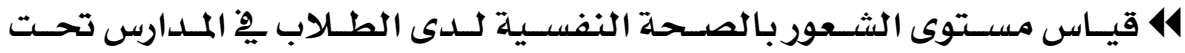
الدراسة.

14 إيجاد علاقة ارتباطية ذات دلالدة إحصائية بين مستوى وجود السـلامهة النفسيـة

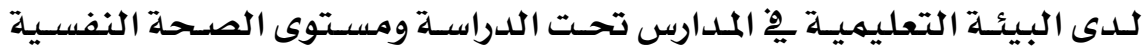

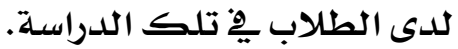

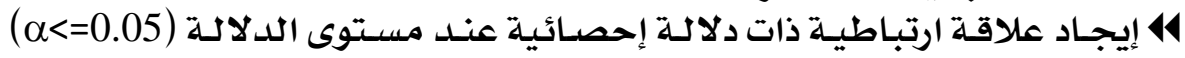

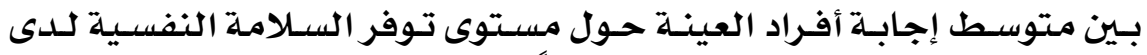

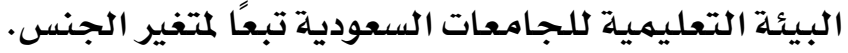


العقى الستون .. الجزء الثخانهى .. أبريل .. ها•مه

•أهمية الدراسة النظرية والتطبيقية:

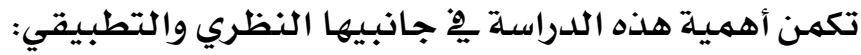

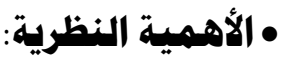

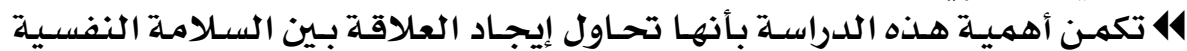

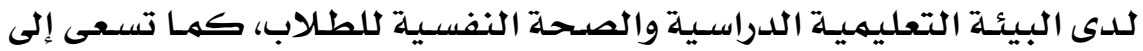

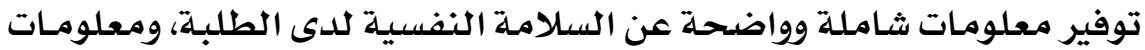
عن الصحة النفسية. 14 يعدّ موضوع السلامة النفسية والصحة النفسية النفي من الموضوعات الحديثة نوعًا

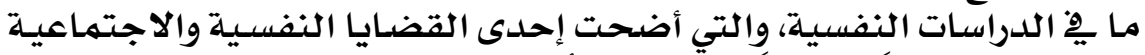

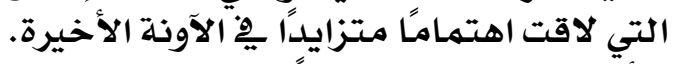

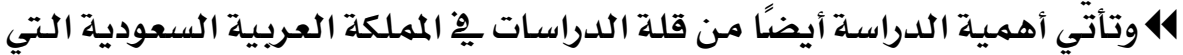

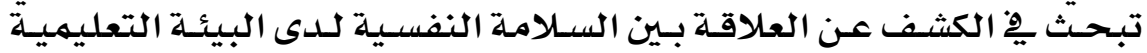

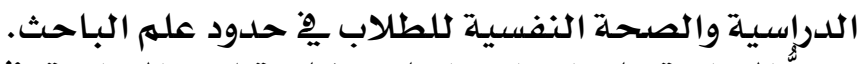

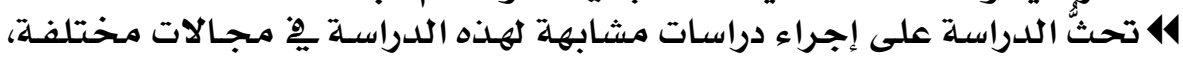
ومراحل دراسية مختلفة الدراسة

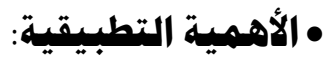

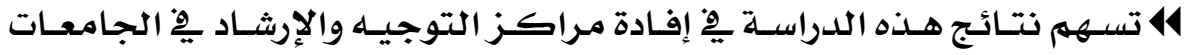

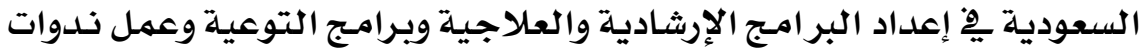

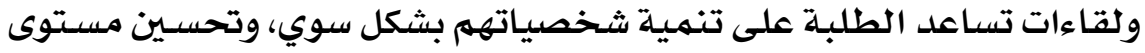

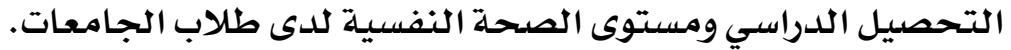

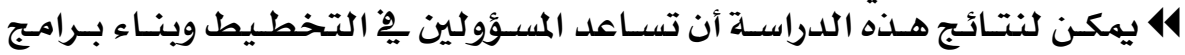

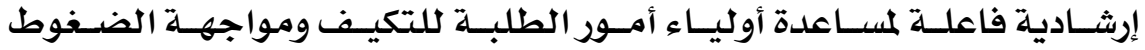

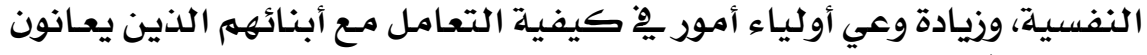

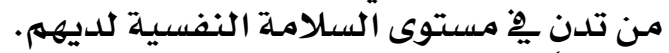

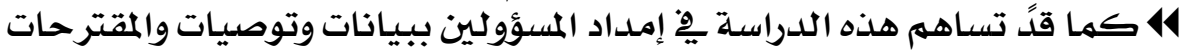

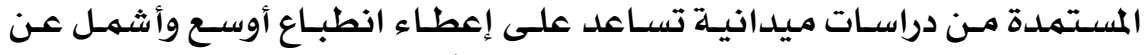

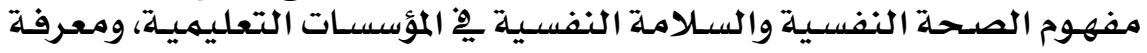

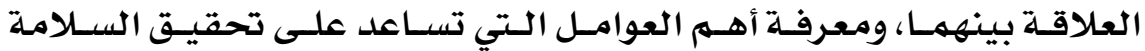

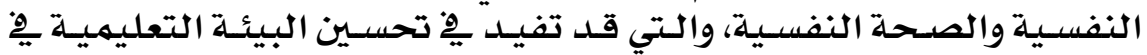

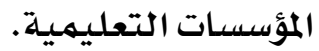

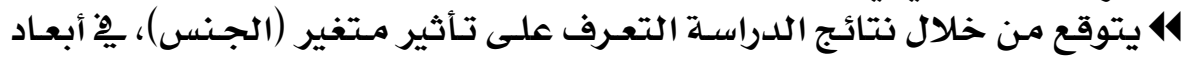

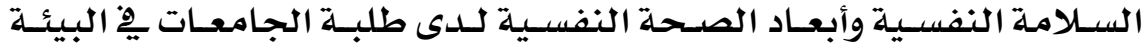

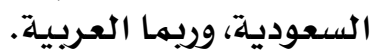

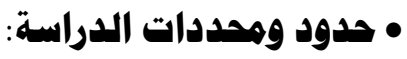
يمكن تعميم نتائج الدراسة يِّ ضوء الحدود والمحددات الآتية: 


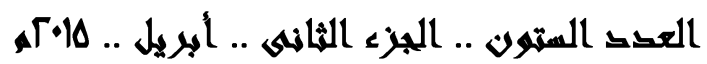

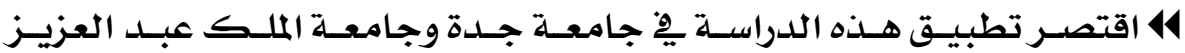

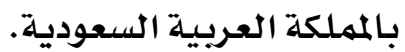

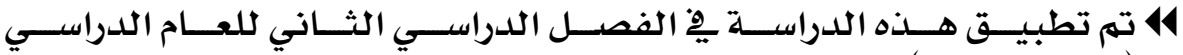

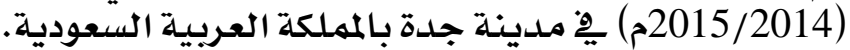

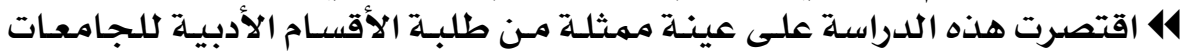

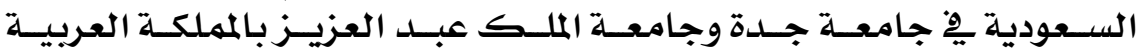
السعودية.

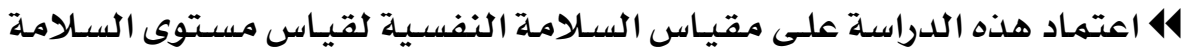

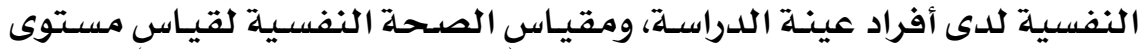

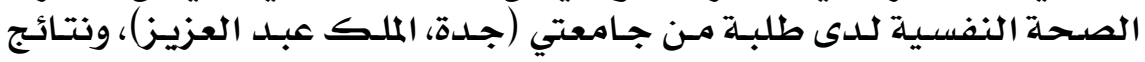

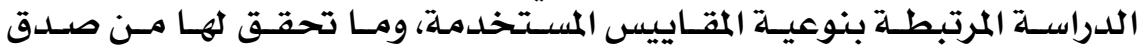
وثبات.

\section{• (مصطات الدراسة:} • البيئة الآمنة نفسيًً:

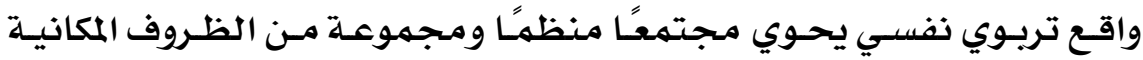

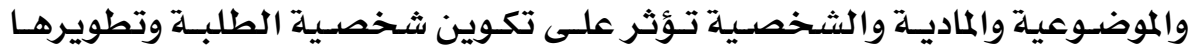

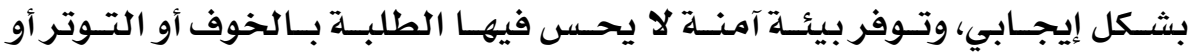

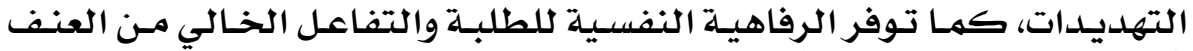
(Kislyakov et al., 2014)

• البيئة التعليمية:

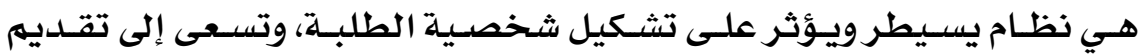

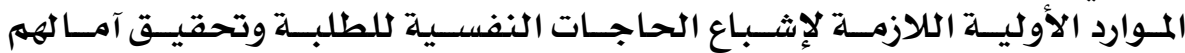

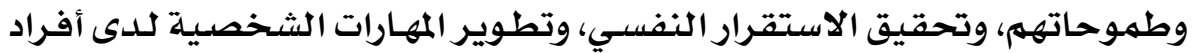

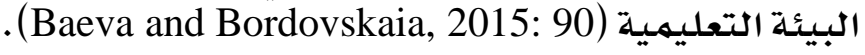

• السلاهة النفسية:

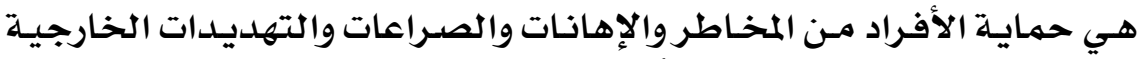

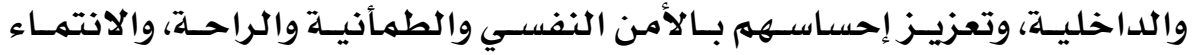

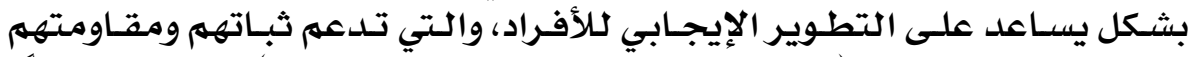

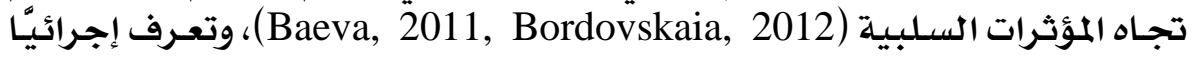

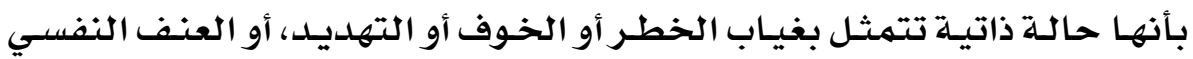

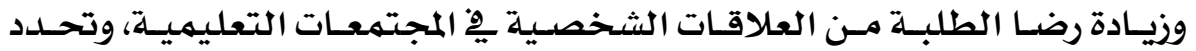

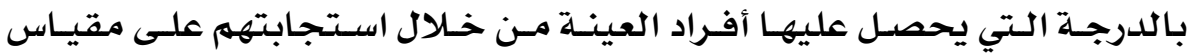

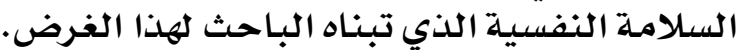


العقى الستون .. الجزء الثلانهى .. أبريل .. ها•مه.

• السلاهية الإجتمامية:

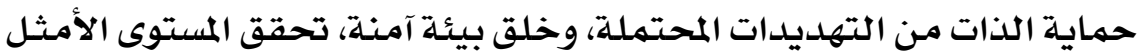

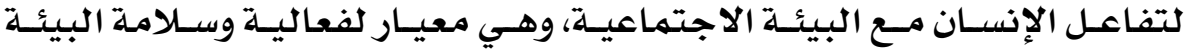

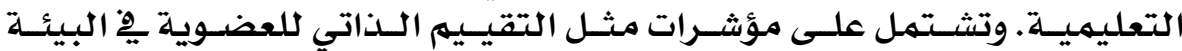

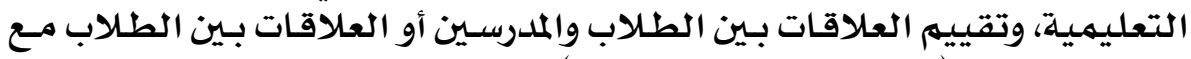
بعضهم البعض (Kislyakov et al., 2014).

• الصحة النفهية

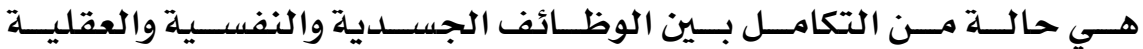

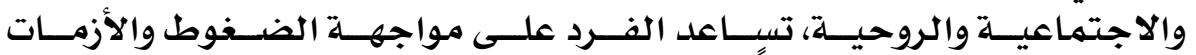

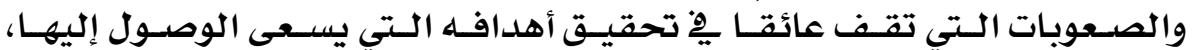

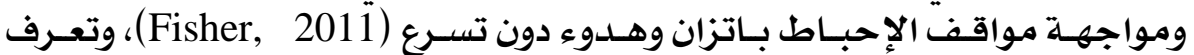

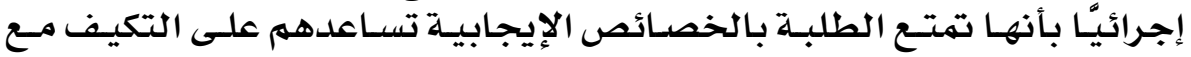

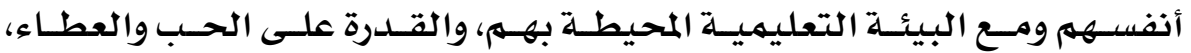

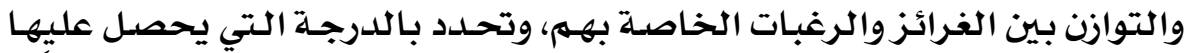

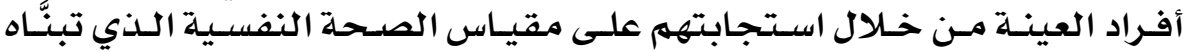
الباحث لهذا الغرض.

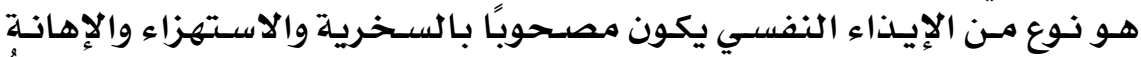

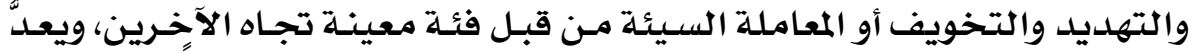

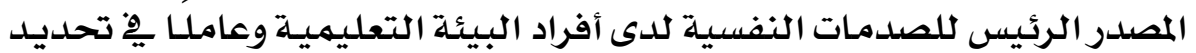

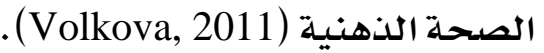

• التهديد النفسي:

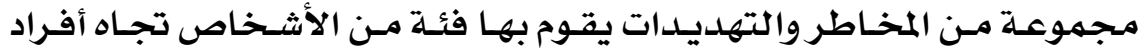

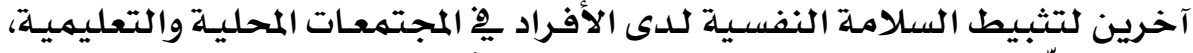

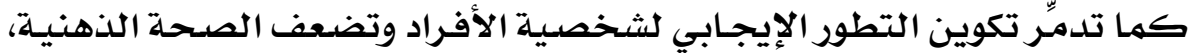

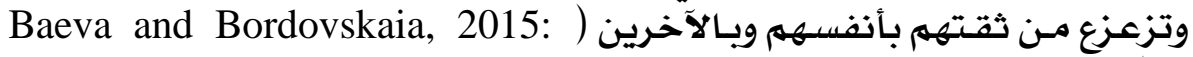

\section{• هنهج الدراسة والإجراءات:

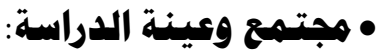

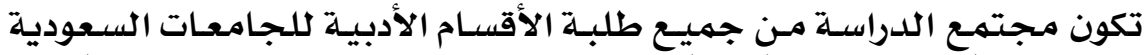

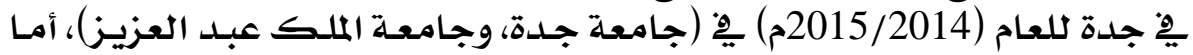
عينـة الدراسـة فقد تم اختيـار (400) طالب وطالبـة مـن طلبـة الأقسـام الأدبيـة. تم

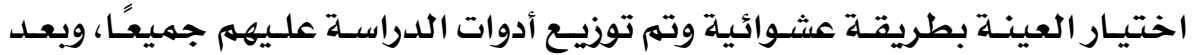




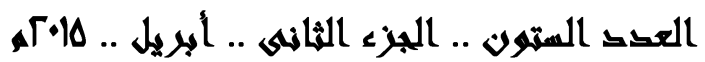

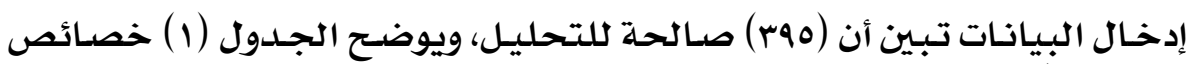

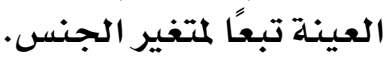

\begin{tabular}{|c|c|c|}
\hline النسبت المئويت & التكراد & المستوى \\
\hline$\varepsilon 9.9$ & $19 \mathrm{~V}$ & ذكر \\
\hline 0.1 & 191 & أثثى \\
\hline $1 \ldots .$. & rao & المحمموع \\
\hline
\end{tabular}

• أدوات جمع البيانات للدراسة:

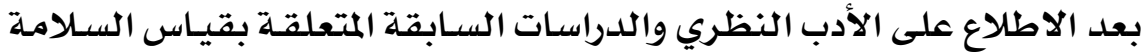

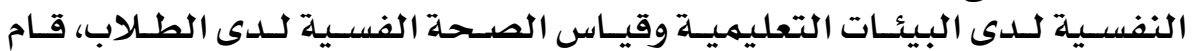

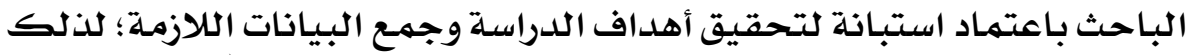

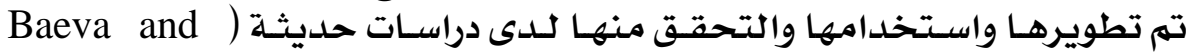

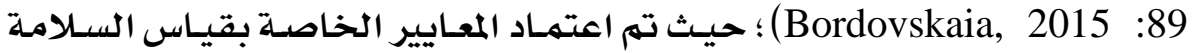

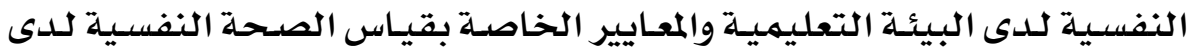

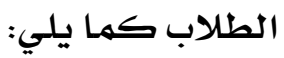
•أولا: هقياس السلاهة النفا: النفية للبيئة التعليمية

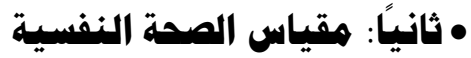

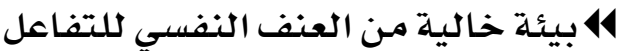

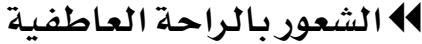

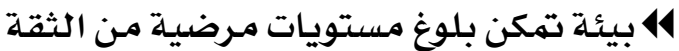
14 14

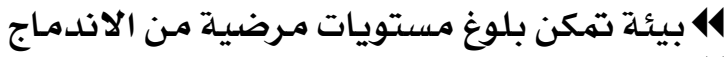

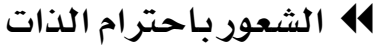

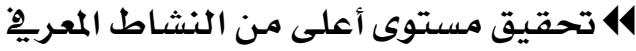

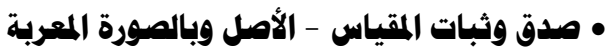

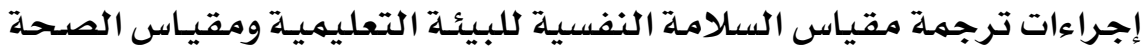

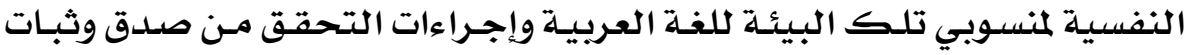
مقياسي الدراسة.

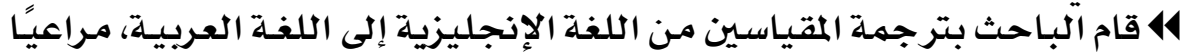

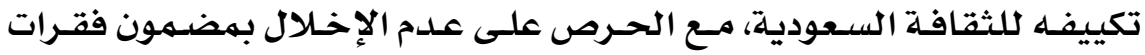

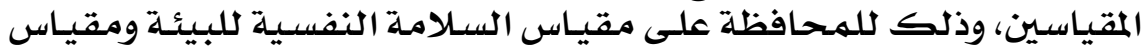

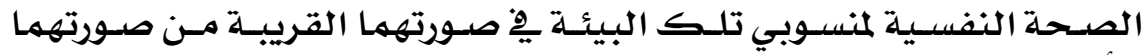
الأوليـة.

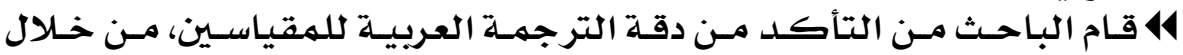

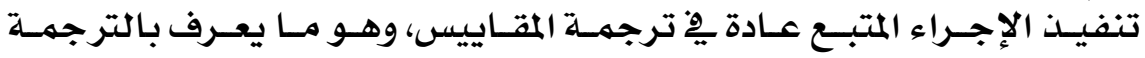




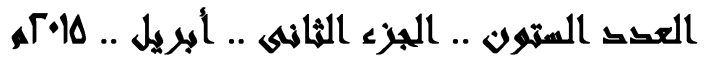

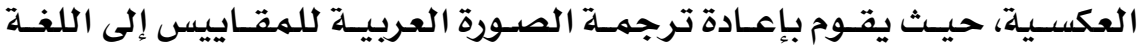

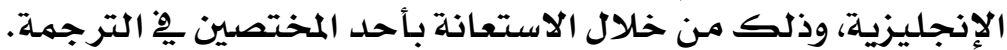

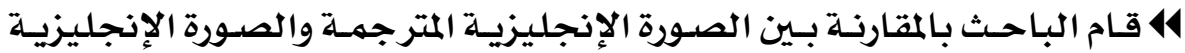

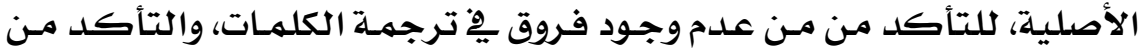

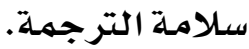

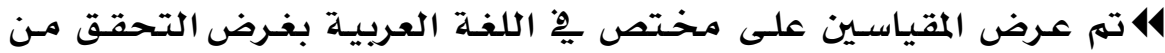

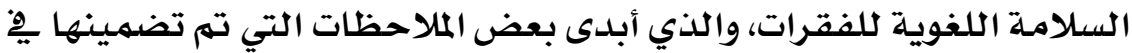

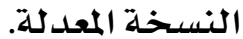

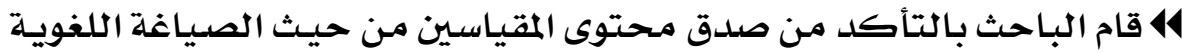

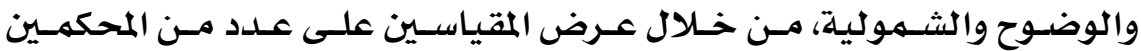

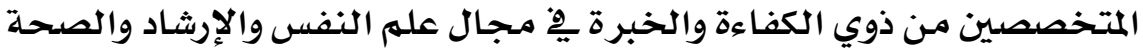
النفسية لإبداء ملاحظاتهم هِّ مضمونها، وتقديم أي اقتراحسات أخرىى يرونها

مناسبة.

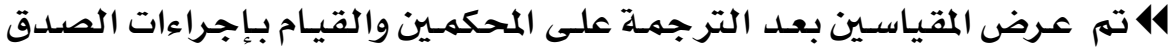

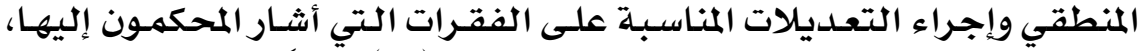

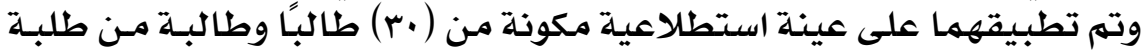

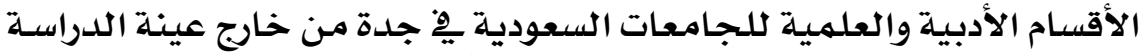

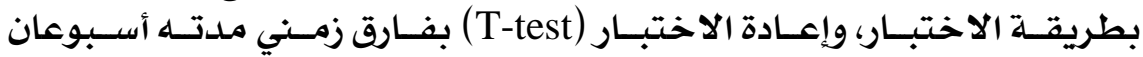

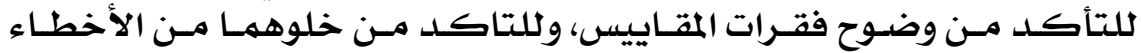

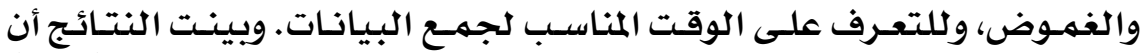

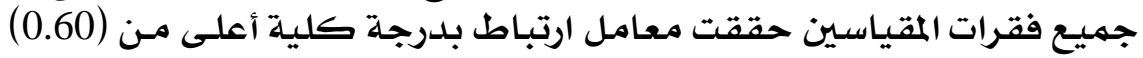

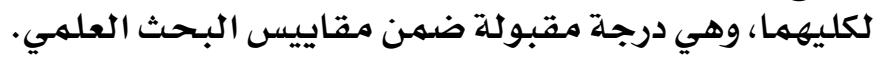

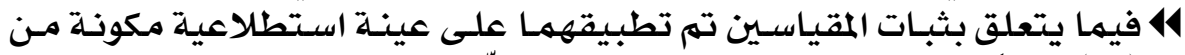

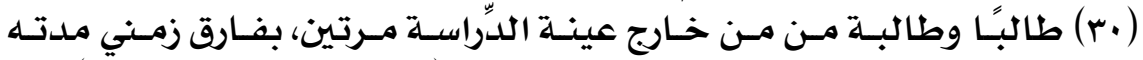

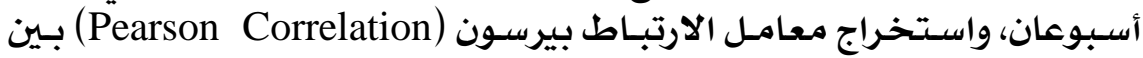

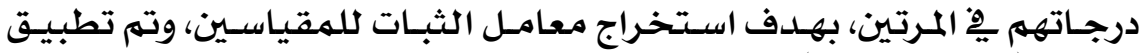

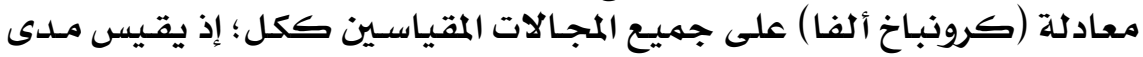

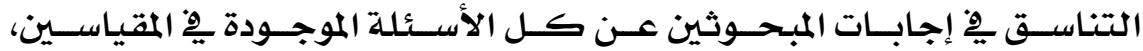

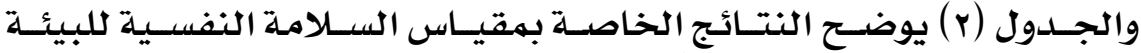

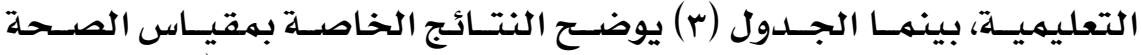

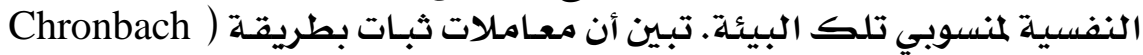
(Alpha

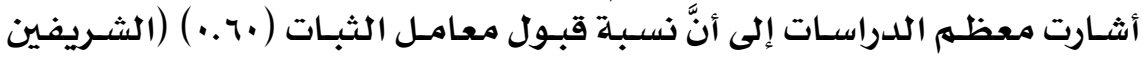

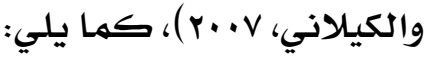


العقد المتهون .. الجزء الثخانهى .. أبريل .. ها·م.

الجلدول (r) : معامل ثبات التطبيق بطريقة بيرسون (Pearson Correlation)، ومعامل ثبات

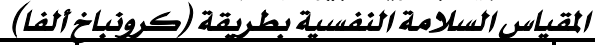

\begin{tabular}{|c|c|c|}
\hline معامل تطبيق بطريفت بيرسون & معامل الثبات بطريقت (كرونباخ الفا) & المجال \\
\hline. $\mathrm{VV}$ & $\bullet \cdot \wedge r$ & بيئتَ تفاعليت آمنت فكريًا \\
\hline .vo & .10 & بيئت إجتماعيت آمنه نفسيًا \\
\hline. $\mathrm{VA}$ & . & بيئت تعليميت تنمويت هامَتز \\
\hline$\cdot \sqrt{ } \mathbf{r}$ & $\bullet .10$ & المجال ككل \\
\hline
\end{tabular}

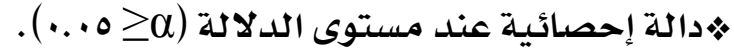

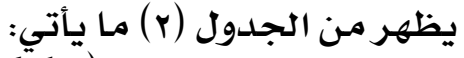

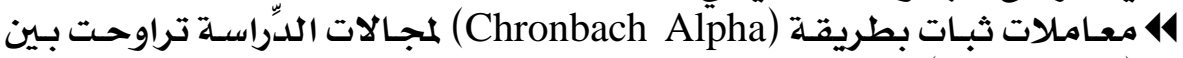

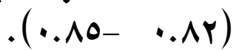

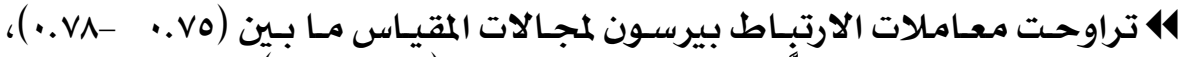

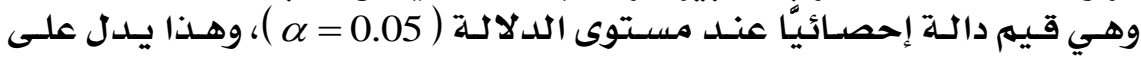
ثبات تطبيق المقياس.

الجلول (r): معامل ثبات التطبيق بطريقة بيرسون (Pearson Correlation) ومعامل ثبات

\begin{tabular}{|c|c|c|}
\hline معامل تطبيق بطريقت & معامل الثبات بطريقن (كروثباخ & المجال \\
\hline. $\mathrm{VI}$ & $\because \wedge 1$ & الشعور بالراحت العاطفيتّوالنفسيتي \\
\hline$\therefore$.vr & 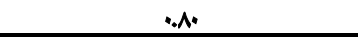 & الشعور بالإستقرار العاطفى \\
\hline.$v \varepsilon$ & $\because .19$ & تحقيق مستوى أعلى من النشاط المعريِ \\
\hline$\because \mathrm{vr}$ & $\bullet .11$ & المجال ككل \\
\hline
\end{tabular}
مقياس الصحة النفسية بطريقة (كرونباخ الفا)

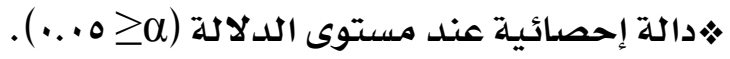

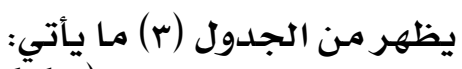

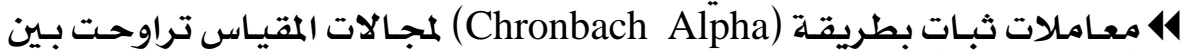

$$
\text { . (•.ی1- - •.v9) }
$$

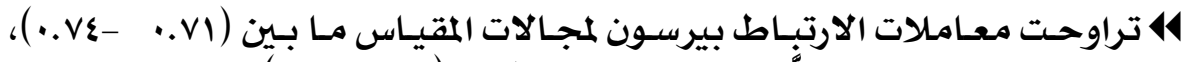

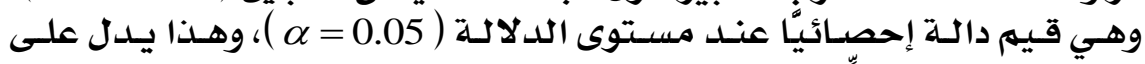
ثبات تطبيق أداة الدِّراسـة.

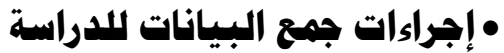

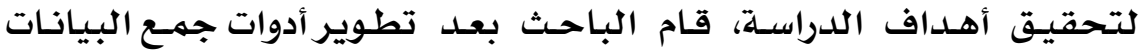

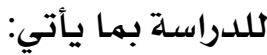

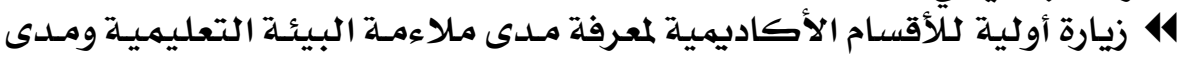

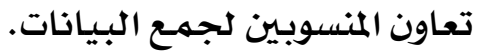

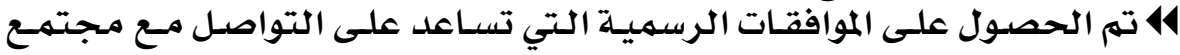
الدراسة وجمع البيانات. 


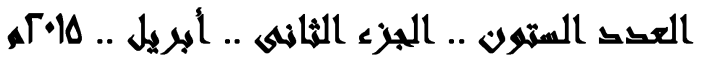

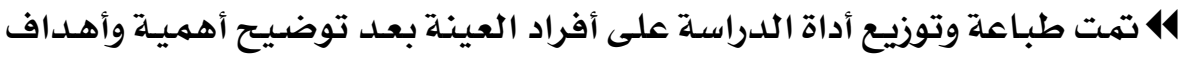

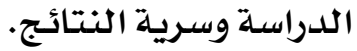

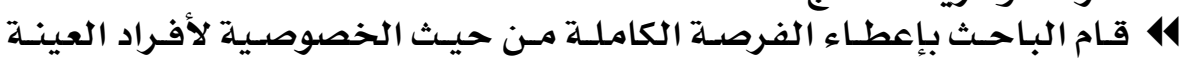
لتعبئة الاستبيان.

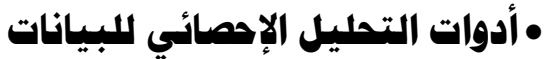

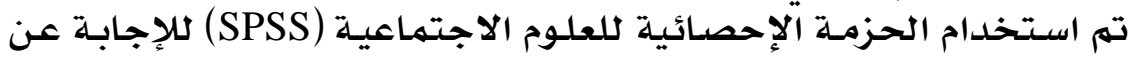

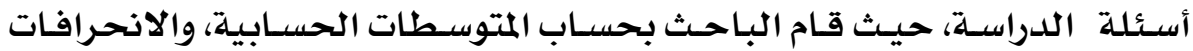

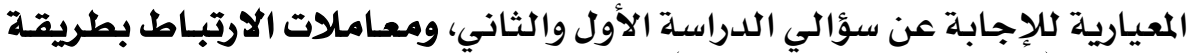

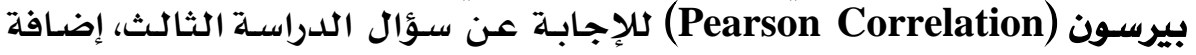

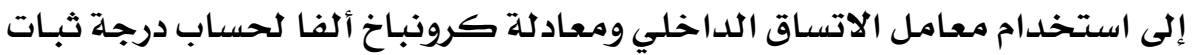

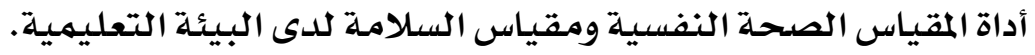

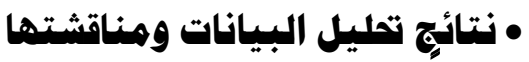

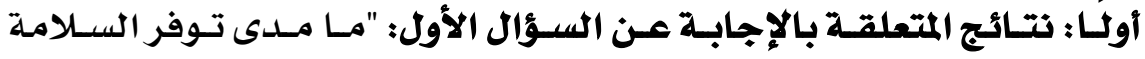

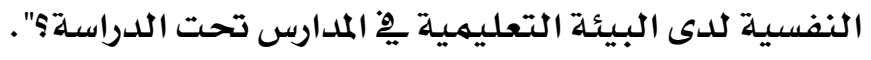

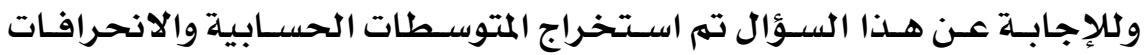

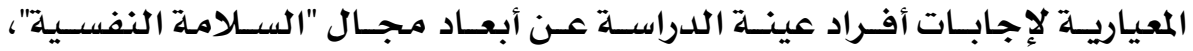

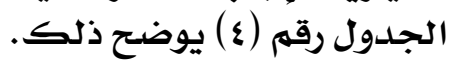

الجدول رقم (ع) : المتوسطات الحسابية، والانحرافات المعيارية لإجابات افراد العينة عن ابعاد مجال

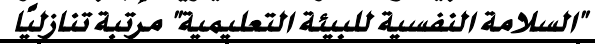

\begin{tabular}{|c|c|c|c|c|c|}
\hline درجتي & الالمعياري & الحسابي & البعد & الرقم - ل الرق & الرتبت \\
\hline مرتفعت & 0.88 & 3.70 & بيئتة اجتماعيت أمنت نفسيًا & $r$ & 1 \\
\hline متوسطت & 0.78 & 3.51 & بيئت تفاعليت آمنت فكريًّ & 1 & $r$ \\
\hline متوسطت & 0.94 & 3.09 & بيئت تعليميتَ تنمويت هامَّت & $r$ & $r$ \\
\hline متوسطت & 0.72 & 3.43 & \multicolumn{3}{|c|}{ المجال ككل } \\
\hline
\end{tabular}

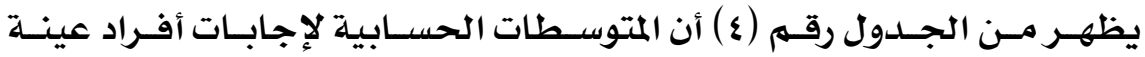

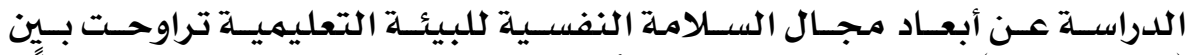

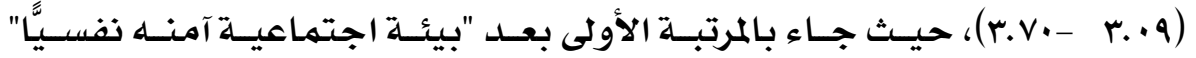

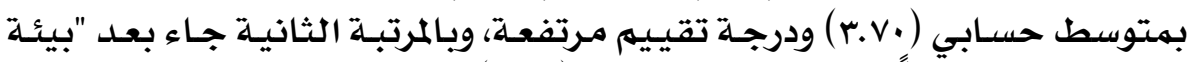

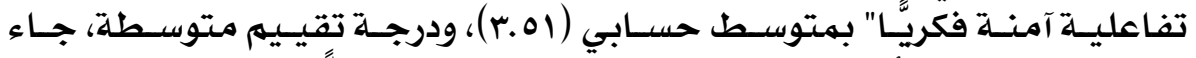

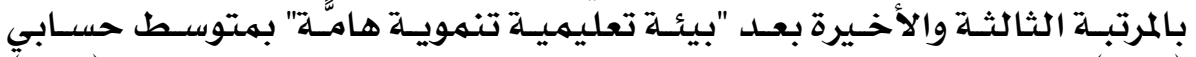

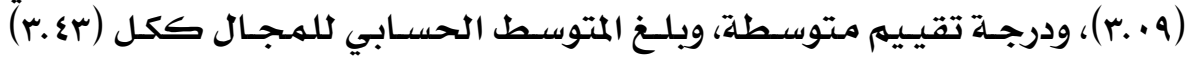

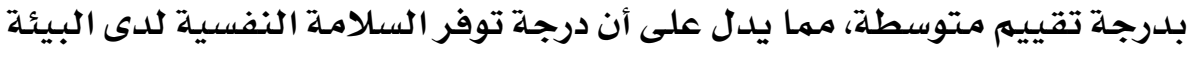

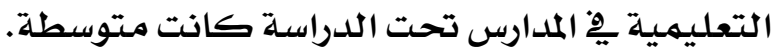




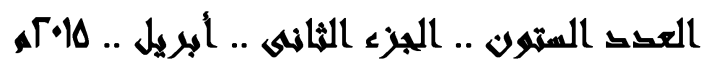

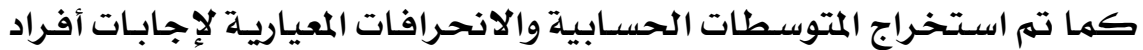

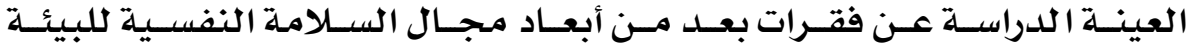

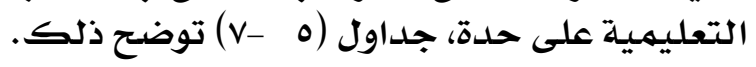

جلدول رقهر (0): المتوسطات الحسابية، والانحرافات المعيارية لإجابات افراد العينة عن فقرات بعلد "بيئة

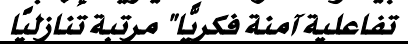

\begin{tabular}{|c|c|c|c|c|c|}
\hline التقيبيم & الانحراف & المسوسطي & الفقرة & الرقم & الرتبت \\
\hline مرتفعت & 1.11 & 3.91 & بيئت الجامعت خاليتّ من العنف النفسي تساعد على التخرين & 1 & 1 \\
\hline متوسطت & 1.07 & 3.65 & بيئت الجامعت تمكن بلوغ مستويات مرضيت من الاندماج & $\varepsilon$ & $r$ \\
\hline متوسطت & 0.99 & 3.35 & بيئت الجامعت تمكن بلوغ مستويات مرضيت من الثقتّ & $r$ & $r$ \\
\hline متوسطت & 1.28 & 3.12 & بيئت الجامعت مناسبت لممارستة حريت التعبير عن الرأي & $r$ & $\varepsilon$ \\
\hline متوسطت & 0.78 & 3.51 & بعد "بيئت تفاعلية آمنت فكريًّ" ككل & & \\
\hline
\end{tabular}

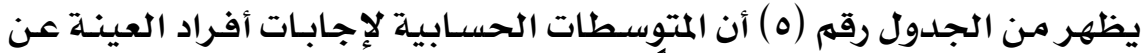

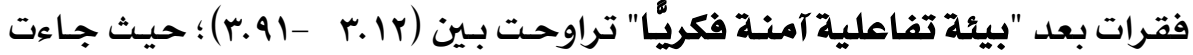

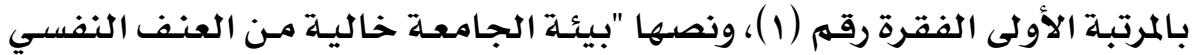

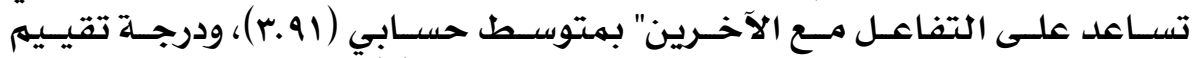

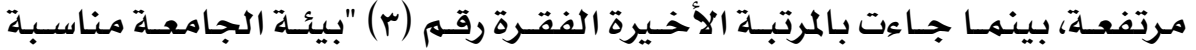

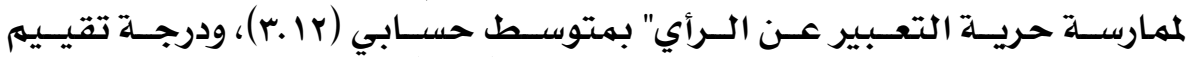

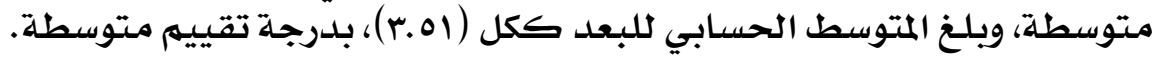

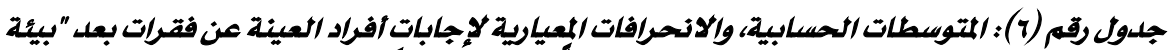
اجتماعية امنة نفسيًا" مرتبة تخنازيليًا

\begin{tabular}{|c|c|c|c|c|c|}
\hline دالتقييم & الالمعياري & المستوسطي & 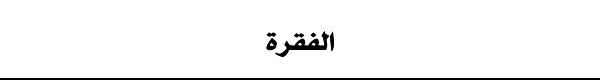 & 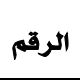 & الرتبت \\
\hline مرتفعت & 1.04 & 3.87 & بيئت الجامعت مناسبت لتنميت الاحترام بالذات وبالآخرين & r & 1 \\
\hline مرتفعت & 1.23 & 3.78 & بيئت الجامعت مناسبت للاحتفاظ بالكرامت الشخصيت & r & r \\
\hline متوسطت & 1.06 & 3.62 & بيئت الجامعت مناسبت لتنميت الشعور الإيجابي & $\varepsilon$ & r \\
\hline متوسطت & 1.07 & 3.54 & بيتَّ الجامعت مناسبت لتنميت الشعور بالانتماء & 1 & $\varepsilon$ \\
\hline مرتفعت & 0.88 & 3.70 & بعد "بيئت اجتماعيت آمنت نفسيًا" ككل & & \\
\hline
\end{tabular}

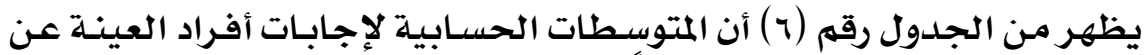

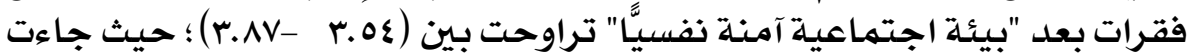

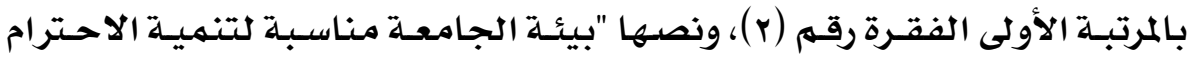




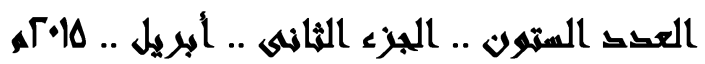

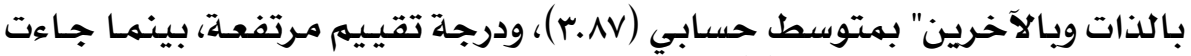

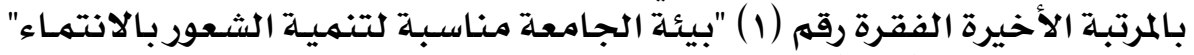

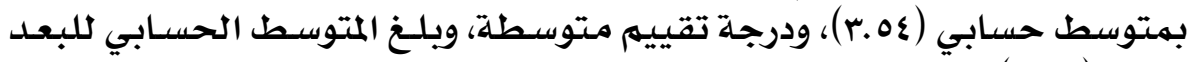

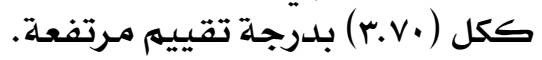

جلدول رقهر (v) : المتوسطات الحسابية، والانحرافات المعيارية لإجابات افراد العينة عن فقرات بعل "بيئة تعليمية تنهوية هامة" مرتبة تنازيليً

\begin{tabular}{|c|c|c|c|c|c|}
\hline التقييم & الانحراف & المتوسطي & الفقرة & 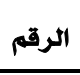 & 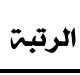 \\
\hline متوسطتة & 1.22 & 3.24 & بيئت الجامعت مناسبت لتنميت روح المثابرة والارتقاء & $\varepsilon$ & 1 \\
\hline متوسطة & 1.17 & 3.09 & بيئت الجامعت مناسبت للحصول على المساعدة عند & 1 & $r$ \\
\hline متوسطت & 1.07 & 3.08 & 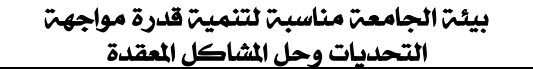 & $r$ & $r$ \\
\hline متوسطة & 1.19 & 2.96 & بيئت الجامعت مناسبت لتنميت قدرات الإببلاع & $r$ & $\varepsilon$ \\
\hline متوسطت & 0.94 & 3.09 & \multicolumn{3}{|l|}{ بعل "بئتة تعليميت تنمويت هامت" ككل } \\
\hline
\end{tabular}

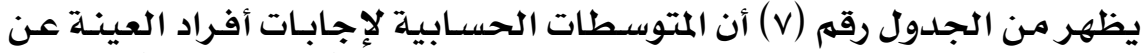

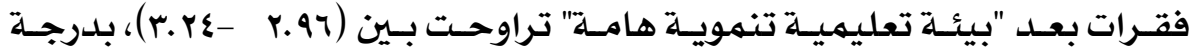

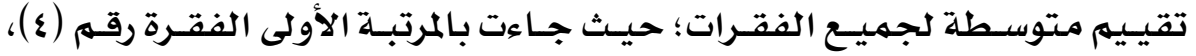

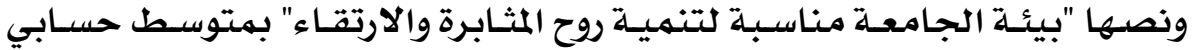

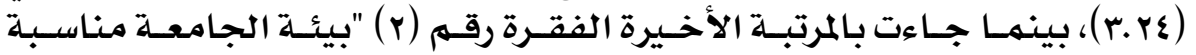

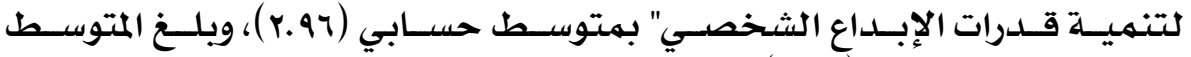

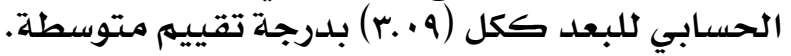

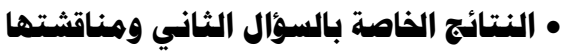

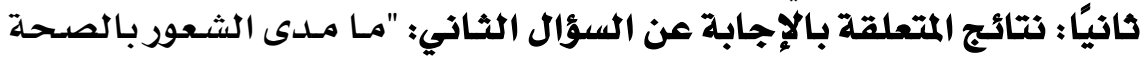

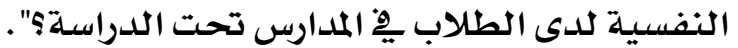

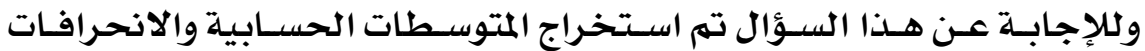

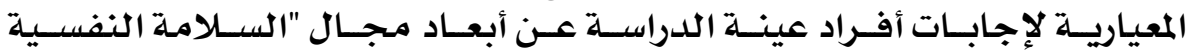

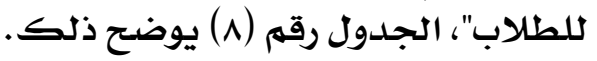

الجلول رقه (1) : المتوسطات الحسابية، والانحرافات المعيارية لإجابات افراد العينة عن ابعاد مجاد العال

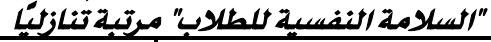

\begin{tabular}{|c|c|c|c|c|c|}
\hline درجتيبي & الالحمراف & الحستوسط & 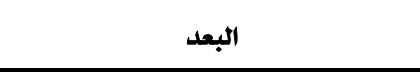 & 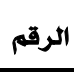 & الرتبت \\
\hline متوسطت & 0.94 & 3.56 & الشعور بالاستقرار العاطفي & $r$ & 1 \\
\hline متوسطت & $\mathbf{0 . 9 7}$ & 3.24 & الشعور بالراحت العاطفيت والنفسيتي & 1 & $r$ \\
\hline متوسطتة & $\mathbf{0 . 8 9}$ & 3.12 & تحقيق مستوى أعلى من النشاط المعريخ & $r$ & $r$ \\
\hline متوسطت & 0.73 & 3.31 & \multicolumn{3}{|l|}{ المجال ككل } \\
\hline
\end{tabular}

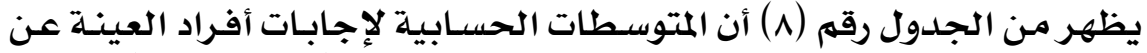

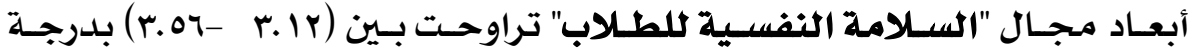




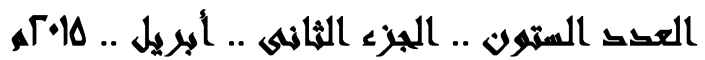

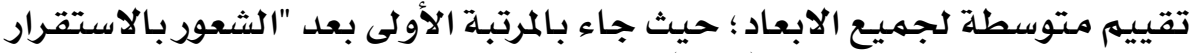

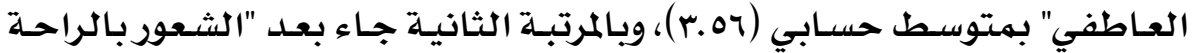

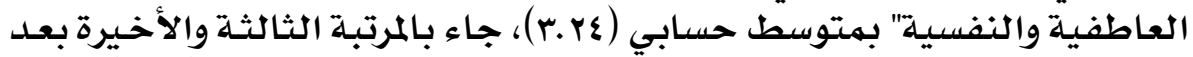

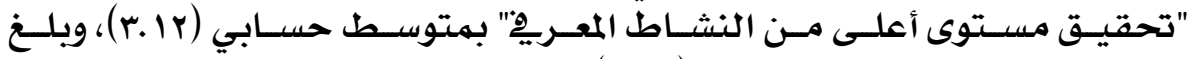

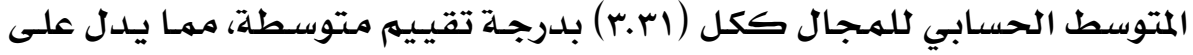

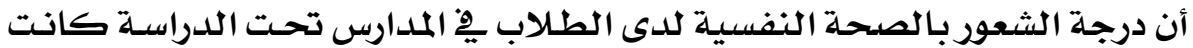
متوسطة.

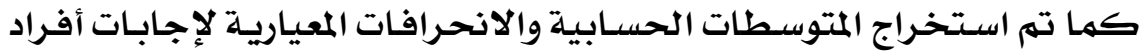

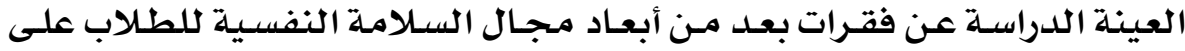

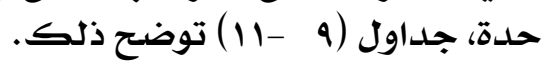

جلدول رقه (ه): المتوسطات الحسابية، والانحرافات المعيارية لإجابات افراد العينة عن فقرات بعل

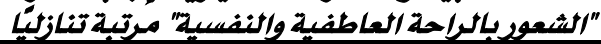

\begin{tabular}{|c|c|c|c|c|c|}
\hline التقيبم & الانحراف & المستوسط & 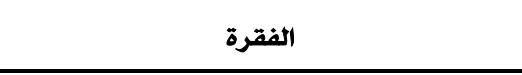 & 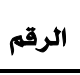 & الرتبت \\
\hline متوسطن & 1.17 & 3.53 & أثعر بأن الحياة ممتعت بين أفراد مجتمع جامعى & $\varepsilon$ & 1 \\
\hline متوسطت & 1.37 & 3.37 & أشعر بالرغبتَ 2. الاستمراريت للحياة الجامعية & 0 & $r$ \\
\hline متوسطت & 1.14 & 3.29 & بئتش الجامعت مجتمع حقيقي يشجع على العيش فيه & 1 & $r$ \\
\hline متوسطت & 1.17 & 3.08 & أثعر بنشاط جسلدي حقيقي عند حضوري & $r$ & $\varepsilon$ \\
\hline متوسطت & 1.17 & 2.94 & أثعر بعاطفتي ثشطت ودافئت عندما أكون 2 & $Y$ & 0 \\
\hline متوسطت & 0.97 & 3.24 & \multicolumn{3}{|c|}{ بعد "الشعور بالراحت العاطفيت والنفسيت" ككل } \\
\hline
\end{tabular}

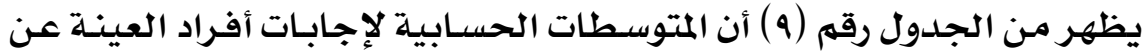

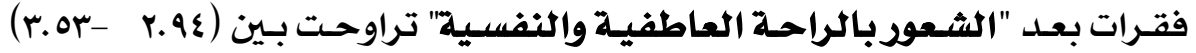

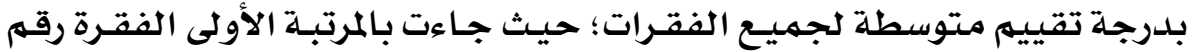

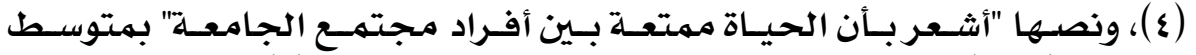

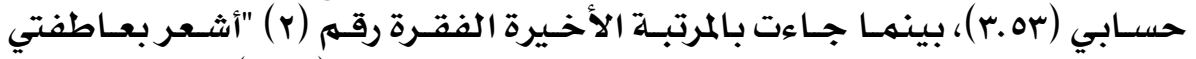

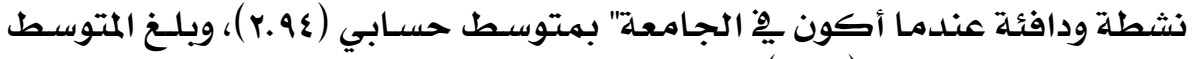

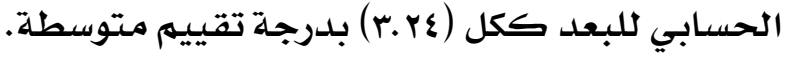
جلول رقهر ( 1 ) : المتوسطات الحسابية، والانحرافات المعيارية لإجابات افراد العينة عن فقرات بعل

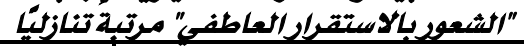

\begin{tabular}{|c|c|c|c|c|c|}
\hline التقييم & الانحياري & المتوسبط & الفقرة & 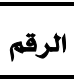 & 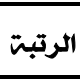 \\
\hline مرتفعت & 1.01 & 3.91 & أثعر باحترام ذاتى عندما أكون ـِ الجامعت & $r$ & 1 \\
\hline مرتفعت & 1.01 & 3.77 & أشعر بالثقت بالنفس عندما أكون ِ2 الجامعت & $r$ & $r$ \\
\hline متوسطتة & 1.21 & 3.40 & أثعر بالراحت والاستقرار النفسي هُ بيئت جامعتى & 1 & $r$ \\
\hline متوسطتة & 1.13 & 3.40 & تكون مشاعرى إيحابيت عندما أكون 2ِ الجامعت & $\varepsilon$ & $r$ \\
\hline متوسطتة & 1.37 & 3.34 & 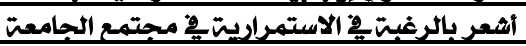 & 0 & 0 \\
\hline متوسطت & 0.94 & 3.56 & "الشعور بالاستقرار العاطفى" ككل & & \\
\hline
\end{tabular}




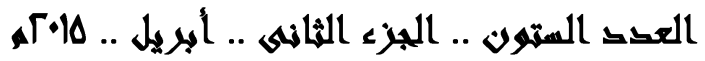

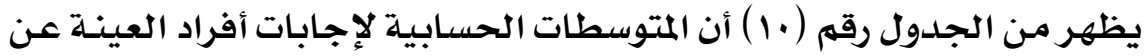

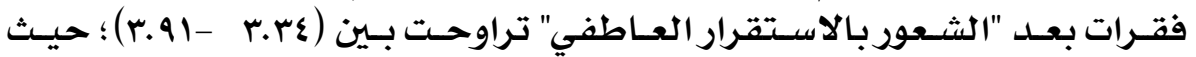

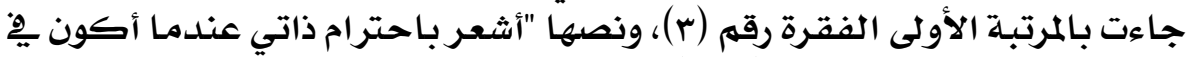

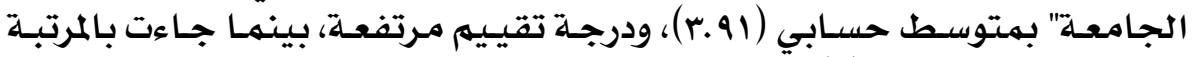

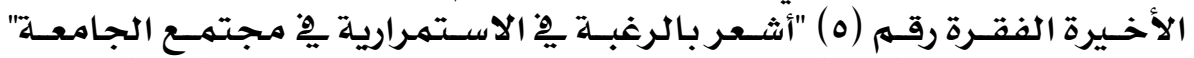

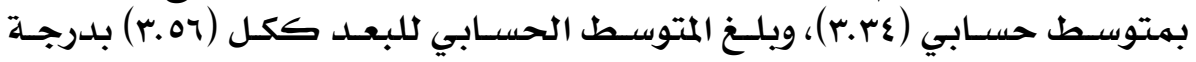

تقييم متوسطة.

جلدول رقه (1 1 ) : المتوسطات الحسابية، والانحرافات المعيارية لإجابات أفراد العينة عن فقرات بعل

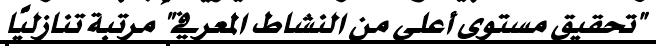

\begin{tabular}{|c|c|c|c|c|c|}
\hline التقييم & الالمعياري & الحستوسطي & الفقرة & 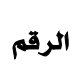 & الرتبت \\
\hline متوسطتة & 1.24 & 3.26 & أتعامل مع المواقف الصعبتَ دون تعريض نفسي لأي & 0 & 1 \\
\hline متوسطت & 1.11 & 3.20 & أثعر إيجابيًا بإمكانيات وقدرات علميت لحل & $r$ & $r$ \\
\hline متوسطت & 1.07 & 3.07 & أثعر بنشاط فكري ومعربحِ حقيقي عند حضوري & $\varepsilon$ & $r$ \\
\hline متوسطت & 1.30 & 3.05 & أقوم دائمًا بتنفيذ واجباتي التعليميت بالشكل & $r$ & $\varepsilon$ \\
\hline متوسطت & 1.31 & 2.99 & أرغب أن أشارك بِ نشاطات للتنميت المعرفيتشِّ & 1 & 0 \\
\hline متوسطت & 0.89 & 3.12 & ق مستوى أعلى من النشاط المعربِّ" ككل & 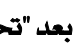 & \\
\hline
\end{tabular}

يظهر من الجـدول رقم (11) أن المتوسطات الحسـابيـة لإجابات أفراد العينـة عن

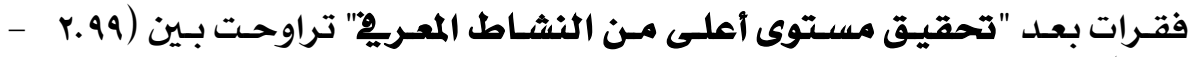

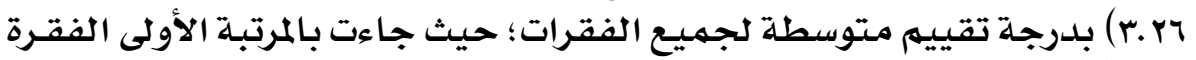

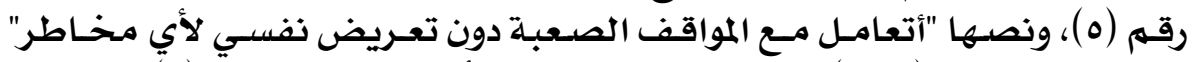

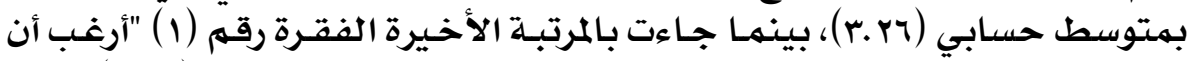

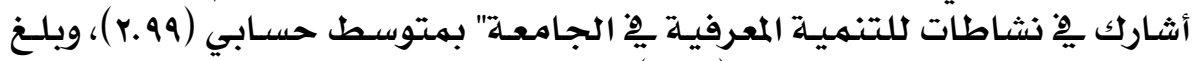

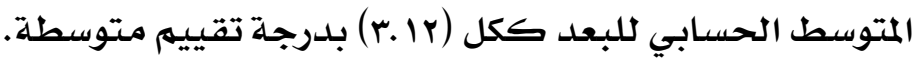

• النتائج الخاصة بالسؤال الثالث وهناقشتها

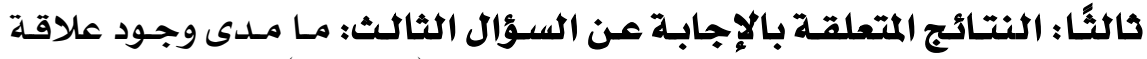

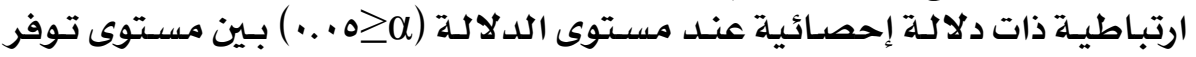

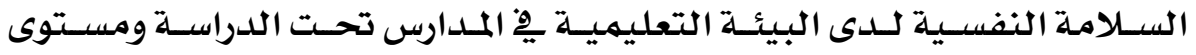
الشعور بالصححة النفسية لدى الطلاب يخ فتلك الدراسلة 


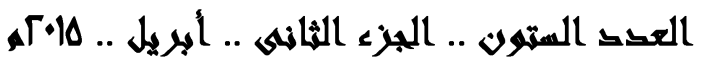

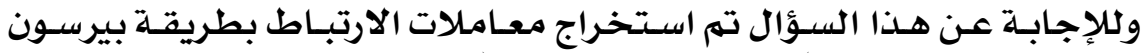

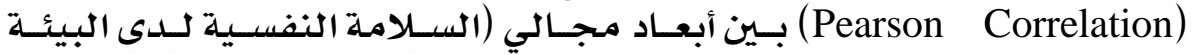

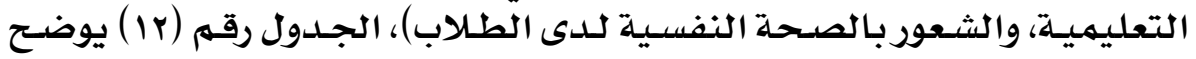

الجدول رقم (ir) : معاملات الارتباط بطريقة بيرسون (Pearson Correlation) بين ابعاد مجالي

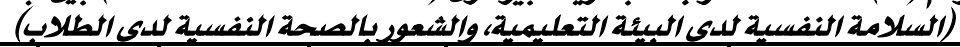

\begin{tabular}{|c|c|c|c|c|c|}
\hline النطفيتً & المستوى المنى & بالاستقرار & والعالراحيتة & & المجال \\
\hline $0.63^{*}$ & $0.51^{*}$ & $0.54 *$ & $0.51 *$ & معامل الارتباط & \multirow{3}{*}{ بيئت تفاعليتَآمنت فكريًا } \\
\hline$\therefore$ & $\therefore$ & $\therefore$ & $\therefore$ & الدلالت الإحصائيتة & \\
\hline rao & rao & rao & r90 & العدد & \\
\hline $0.68^{*}$ & $0.51^{*}$ & $0.62^{*}$ & $0.55^{*}$ & معامل الارتباط & \multirow{3}{*}{ بيئتة اجتماعيت آمنتة نفسيًا } \\
\hline$\cdots$ & $\cdots$ & $\cdots$ & $\cdots$ & الدلالت الإحصائيتي & \\
\hline rag & rao & r90 & rao & 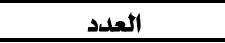 & \\
\hline 0.10* & 0.18* & $0.16^{*}$ & $0.17^{*}$ & معامل الارتباط & \multirow{3}{*}{ بيئت تعليميتَ تنمويت هامتّة } \\
\hline$\ldots$ & $\cdots$ & $\cdots$ & $\because \cdots$ & الدلالت الإحصائيتة & \\
\hline rao & rao & rao & rao & العدد العد & \\
\hline 0.61* & $0.42 *$ & $0.57 *$ & $\mathbf{0 . 5 3}^{*}$ & معامل الارتباط & \multirow{3}{*}{ السلامتيميتفسيت كللبيئت } \\
\hline$\therefore$ & $\cdots$ & $\therefore$ & $\therefore$ & الدلالتَالإحصائيتي & \\
\hline rag & rao & r90 & rao & العدد العد & \\
\hline
\end{tabular}

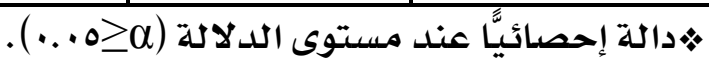

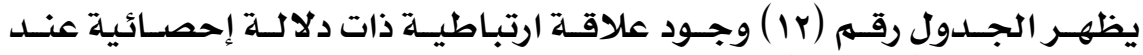

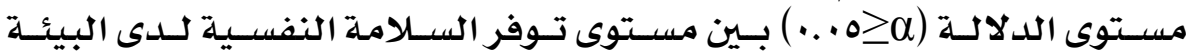

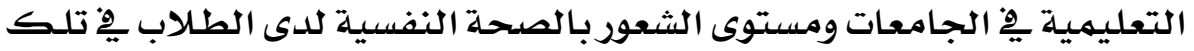

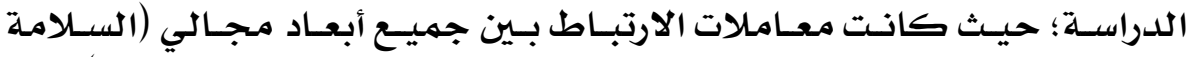

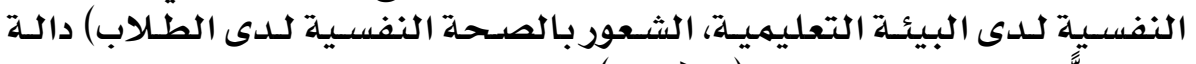

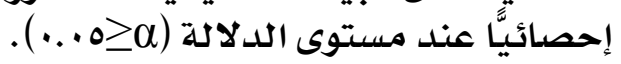

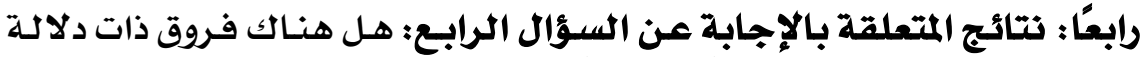

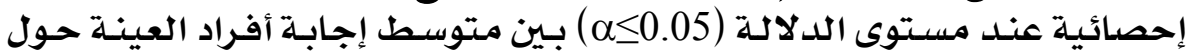

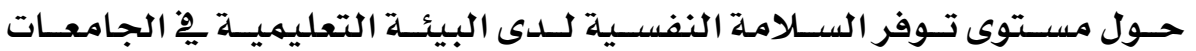

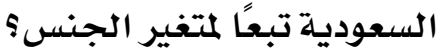

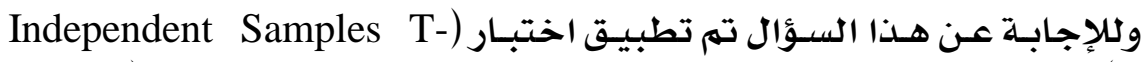

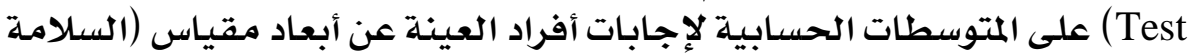

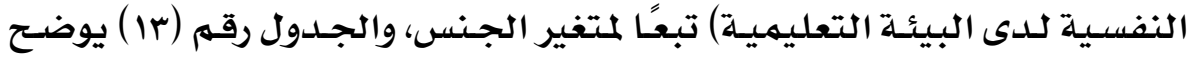


العقى الستون .. الجزء الثلانهى .. أبريل ..

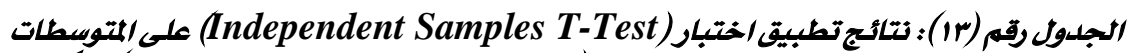
الحسابية لإجابات أفراد العينة عن ابعاد مقياس (السلامة النفسية للى البيئة التعليمية) تبعًا لمتغير

\begin{tabular}{|c|c|c|c|c|c|c|}
\hline \multirow{2}{*}{ الإحصائيت } & \multirow[b]{2}{*}{$\mathbf{T}$} & \multicolumn{2}{|c|}{ إناث } & \multicolumn{2}{|c|}{ ذكور } & \multirow[b]{2}{*}{ أبعاد } \\
\hline & & الانحراف & الحسوسطي & الانحراف & الحستوسط & \\
\hline 0.74 & 0.34 & 0.78 & 3.52 & 0.79 & 3.49 & بيئت تفاعليتة آمنت فكريًاً \\
\hline 0.77 & 0.30 & $\mathbf{0 . 8 8}$ & 3.69 & $\mathbf{0 . 8 8}$ & 3.71 & 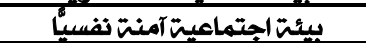 \\
\hline 0.00 & 6.12 & 0.91 & 3.37 & 0.89 & 2.81 & 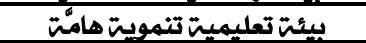 \\
\hline 0.01 & 2.58 & 0.76 & 3.53 & 0.67 & 3.34 & السلامت النفسيت للبيئت التعليميت \\
\hline
\end{tabular}

يظهر الجدول رقم (rال ) ما يلي:

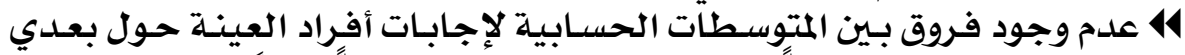

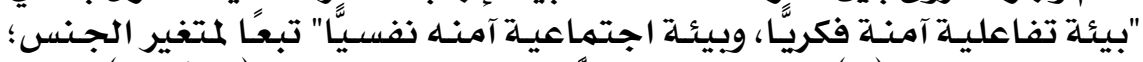

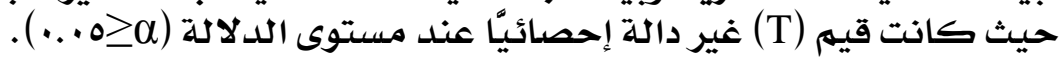

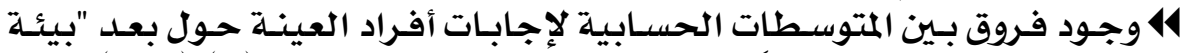

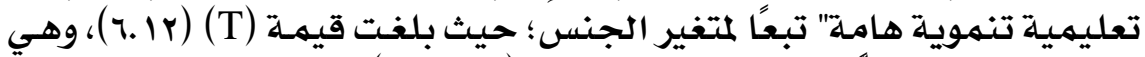

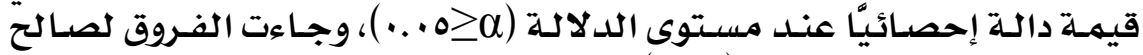

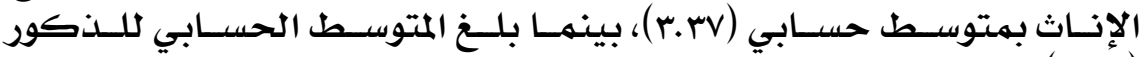
(r.人i)

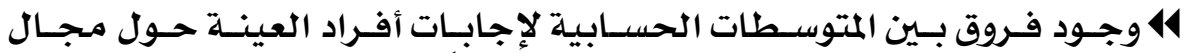

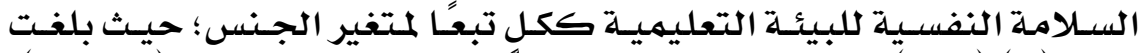

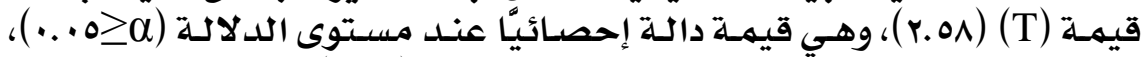

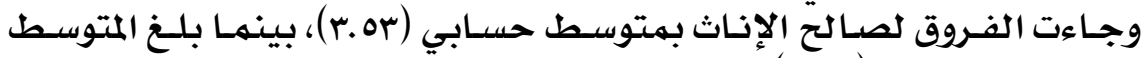

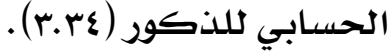

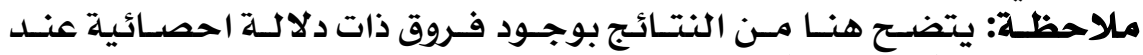

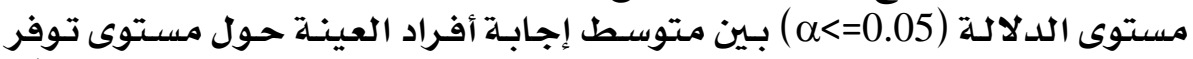

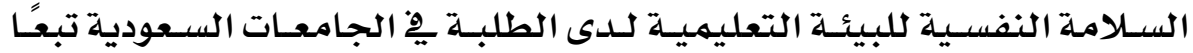
لمتغير الجنس، وجاءت الفروق لصالح الإناث.

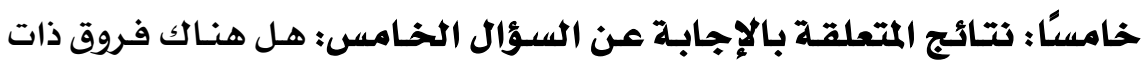

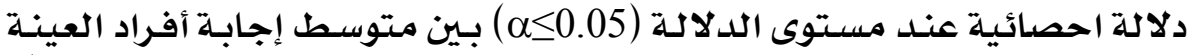

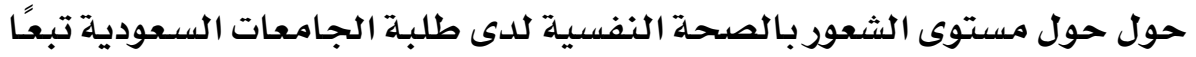
لمتغير الجنس حول مستو؟

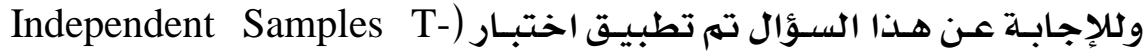

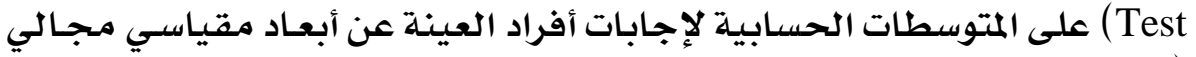

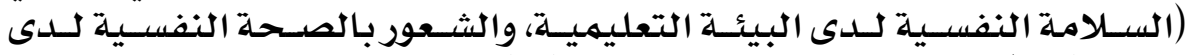

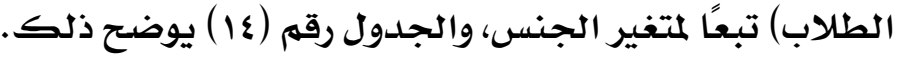




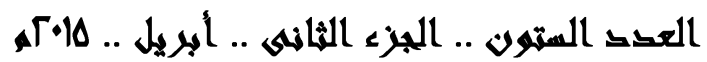

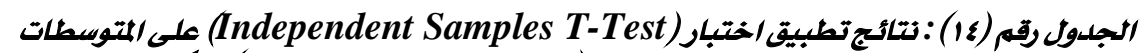

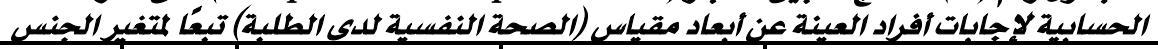

\begin{tabular}{|c|c|c|c|c|c|c|}
\hline \multirow[b]{2}{*}{ الإحصائية } & \multirow[b]{2}{*}{$\mathbf{T}$} & \multicolumn{2}{|c|}{ إناث } & \multicolumn{2}{|c|}{ ذكور } & \multirow[b]{2}{*}{ البعد } \\
\hline & & الانحراف & الحسابي & الالانحراف & الحستوسط & \\
\hline $\mathbf{0 . 0 0}$ & $\mathbf{3 . 0 0}$ & 0.90 & 3.39 & 1.02 & 3.10 & الشعور بالراحت العاطفيت والنفسيت \\
\hline $\mathbf{0 . 0 6}$ & 1.91 & 0.92 & 3.65 & 0.95 & 3.47 & الشعور بالاستقرار العاطفى \\
\hline 0.00 & 11.19 & 0.70 & 2.68 & 0.85 & 3.55 & تحقيق مستوى أعلى من النشاط \\
\hline $\mathbf{0 . 0 7}$ & $\mathbf{1 . 8 4}$ & $\overline{0.63}$ & 3.24 & $\mathbf{0 . 8 1}$ & 3.37 & الصحت النفسيت لدى الطلبت ككل \\
\hline
\end{tabular}

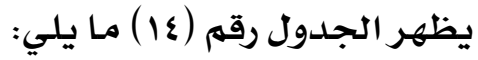

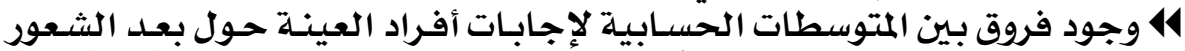

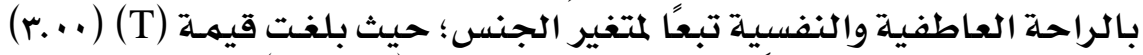

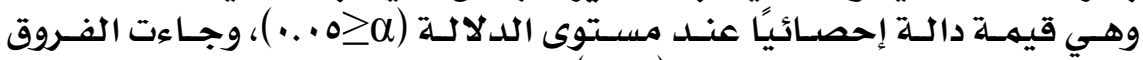

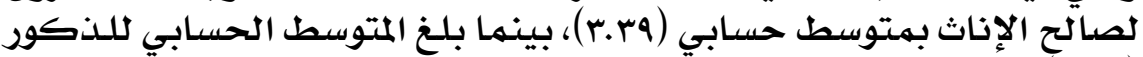

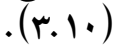

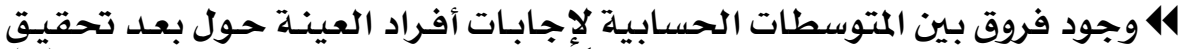

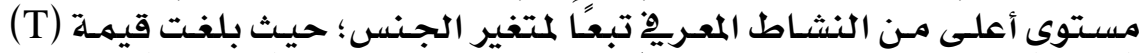

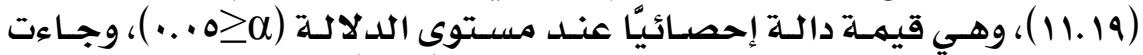

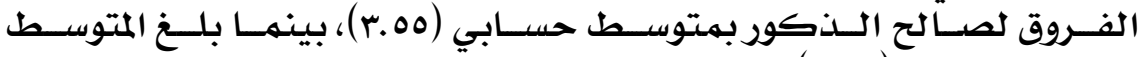

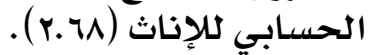

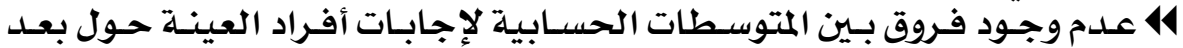

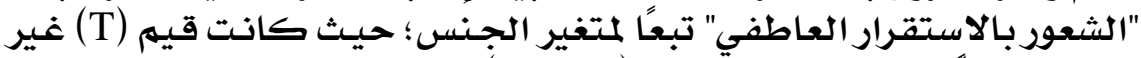

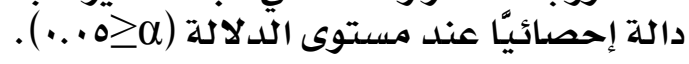

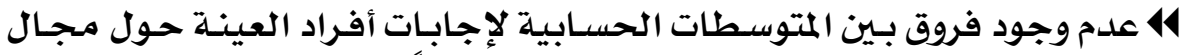

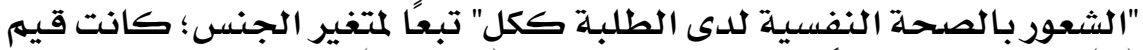

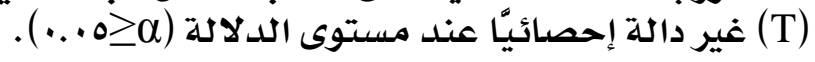

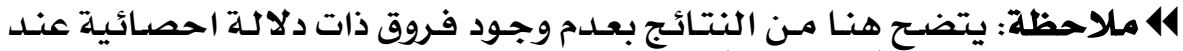

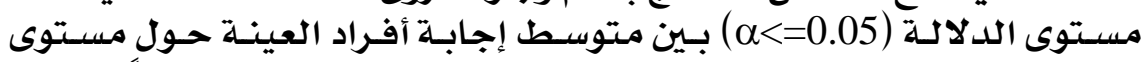

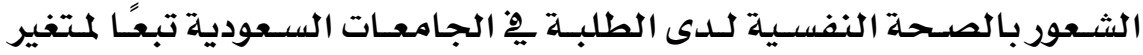

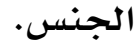

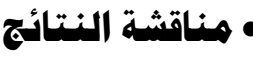 مناقشة نتائج السؤال الأول:}

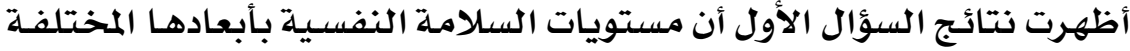

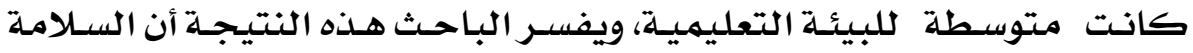

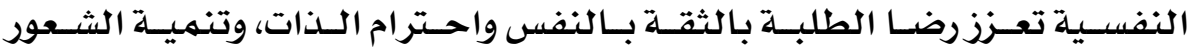

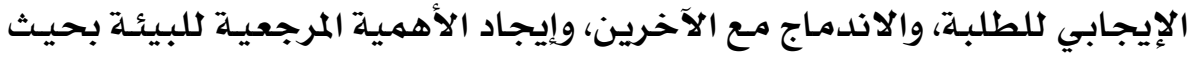

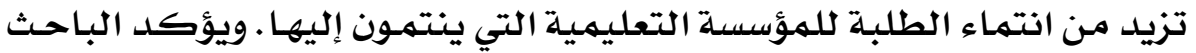




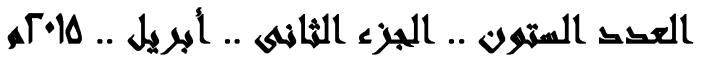

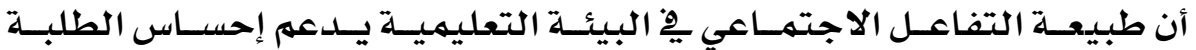

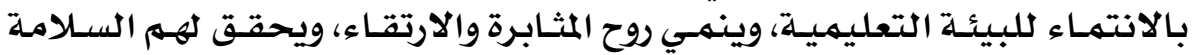
النفسية فيشعرون بـالأمـان وأنهم بعيدون عن الخطـر والخـوف والتهلديدات، وتعـد

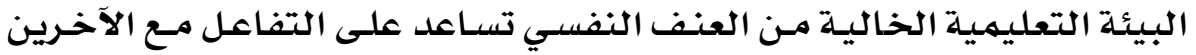

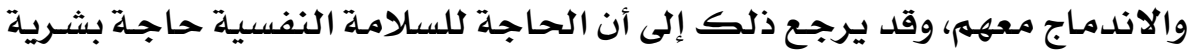

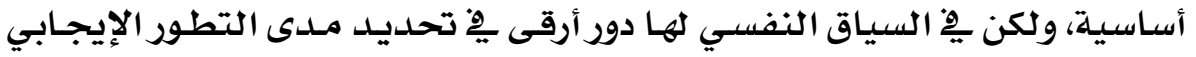

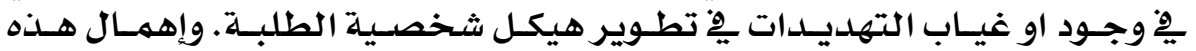

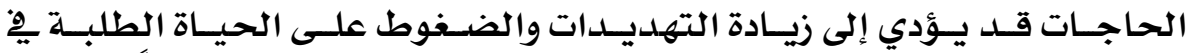

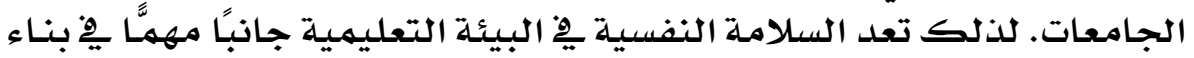

شخصيـة الطلبـة بشكل إيجابي.

Baeva and ordovskaia, ) واختلفـت نتيـجـة الدراسـة الحاسيـة مـع دراســة

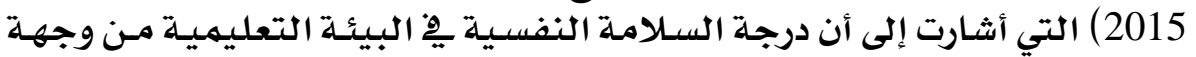

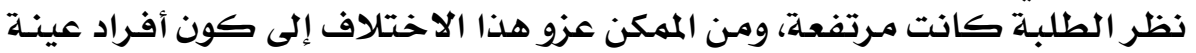

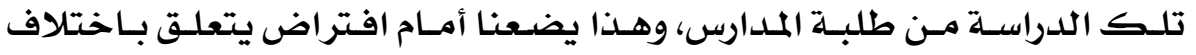

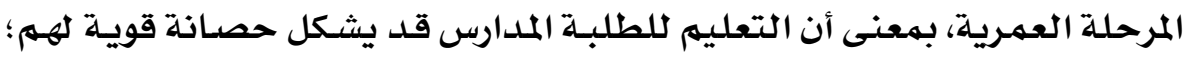

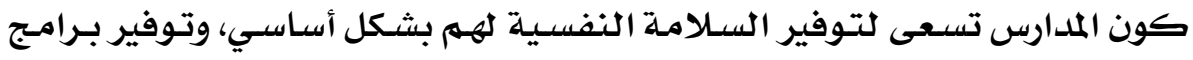
إرثادية وتلدريبية مسـاندة لتحقيق السيلامسة النفسيـية.

\section{مناقشة نتاتُج السؤال الثاني:}

أظهرت نتأُج السؤال الثاني أن مستويـات الصسحة النفسية بأبعادها المختلفة

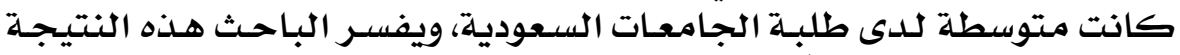

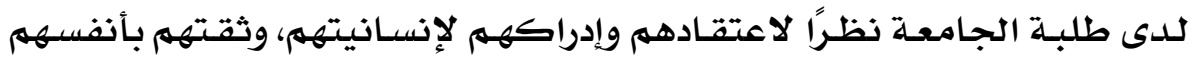

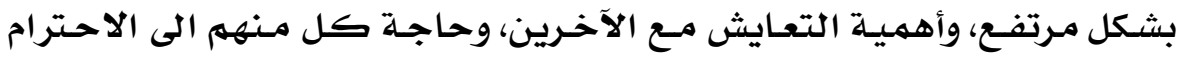

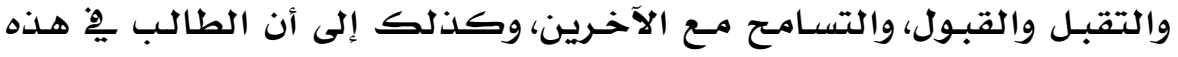

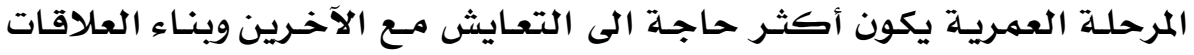

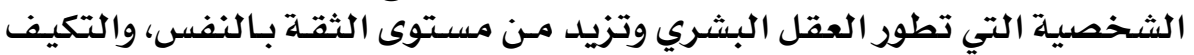

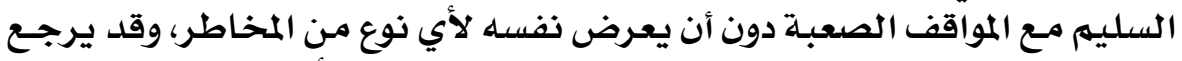

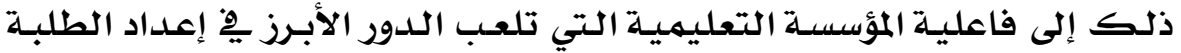

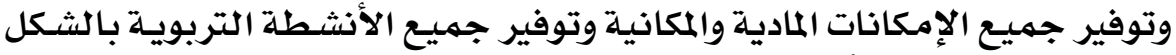

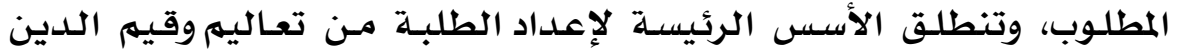

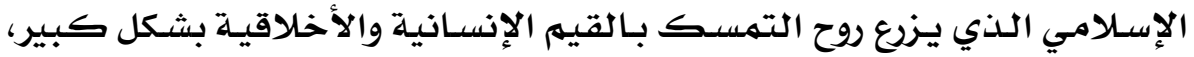

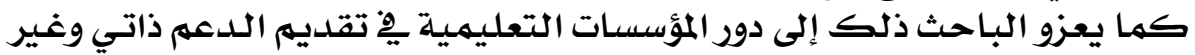

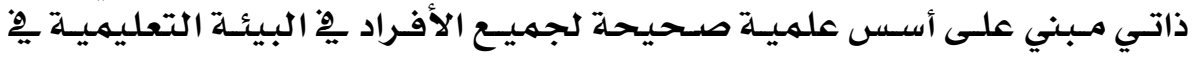

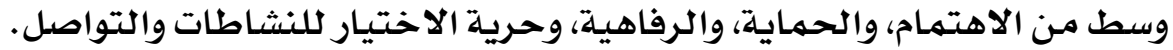


العطى السترلغ .. الجزء الثلانهى .. أبريل ..

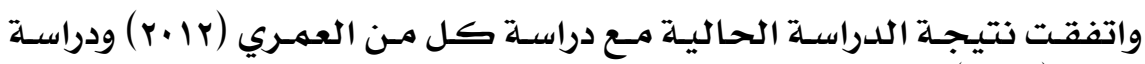

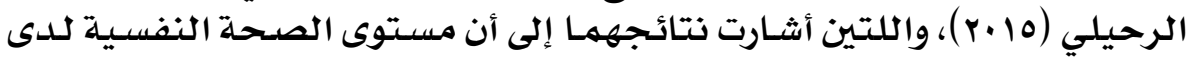

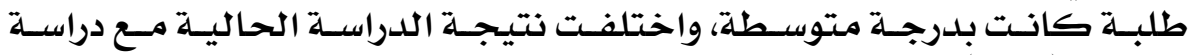

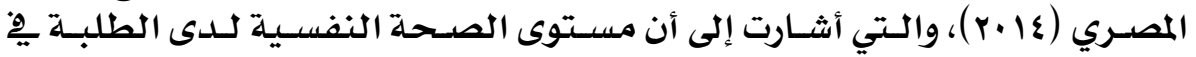

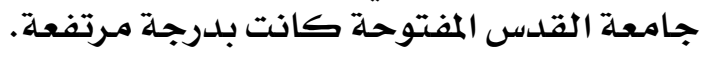

\section{مناقشة ثتاءُج السؤال الثاذث:}

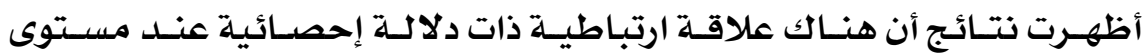

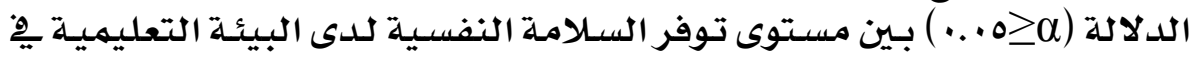

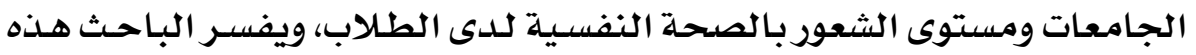

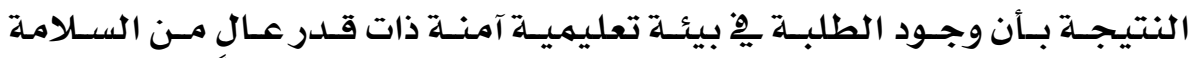

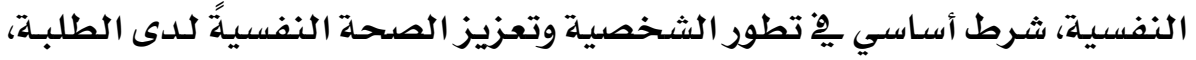

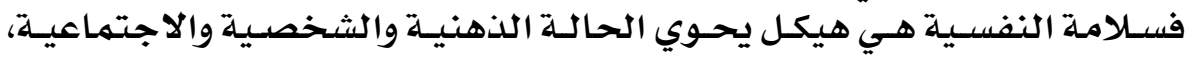

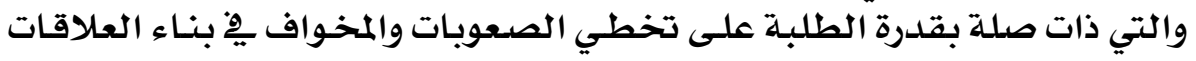

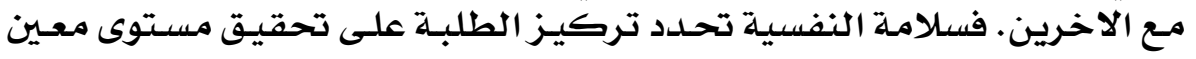

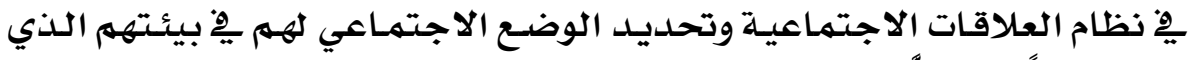

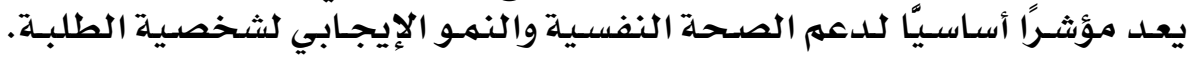

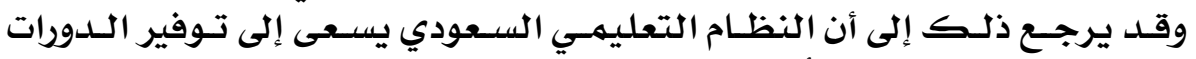

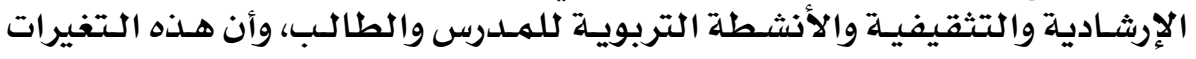

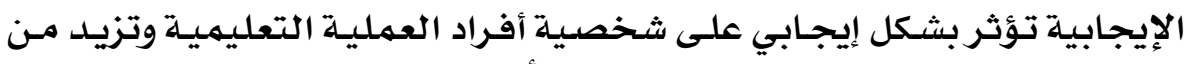

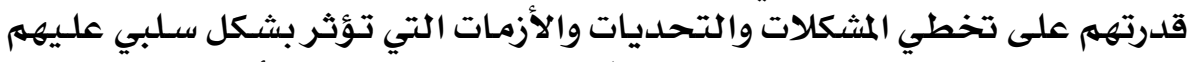

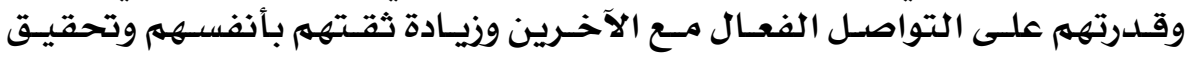

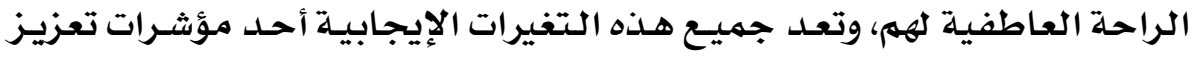

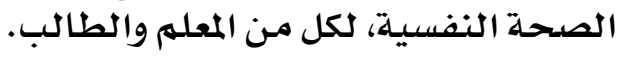

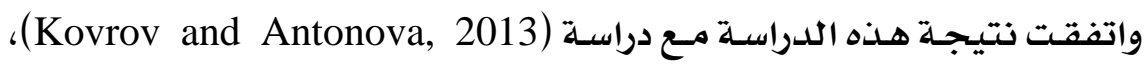

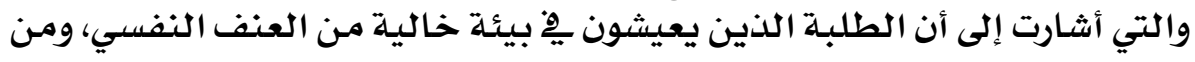

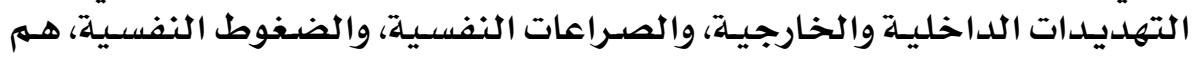

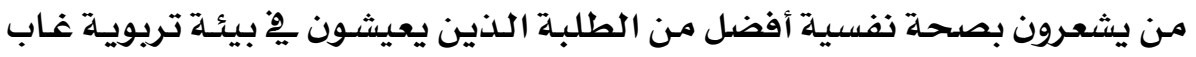

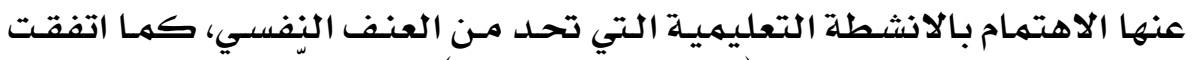

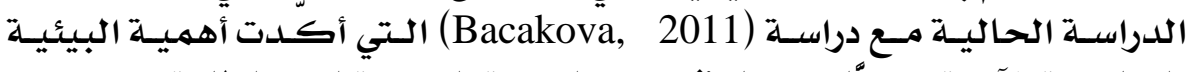

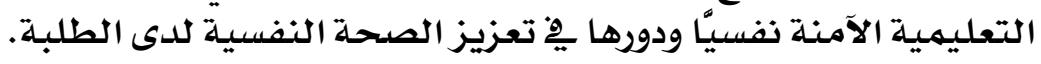

\section{مناقشة نتائج السؤال الرابع:}

أظهـرت النتـائج وجـود فـروق بـين المتوسـطات الحسـابية لإجـابـات أفراد العينـة

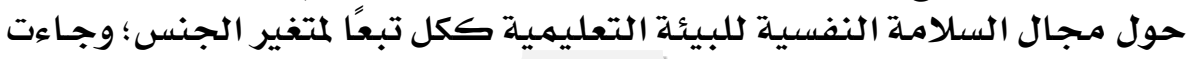




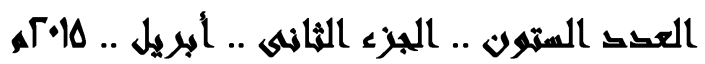

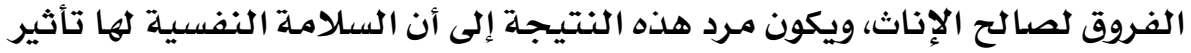

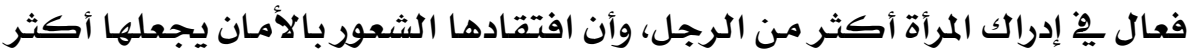

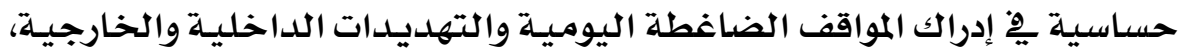

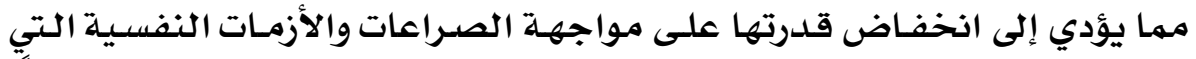

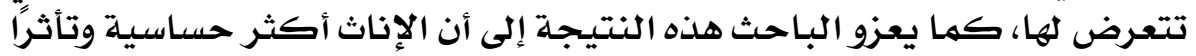

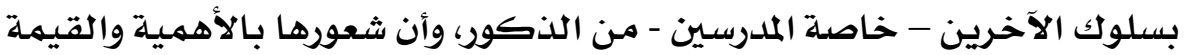

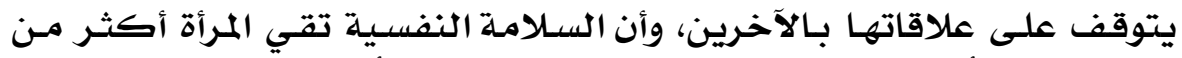

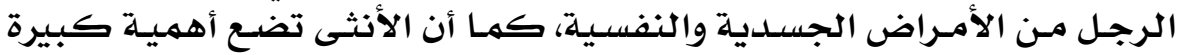

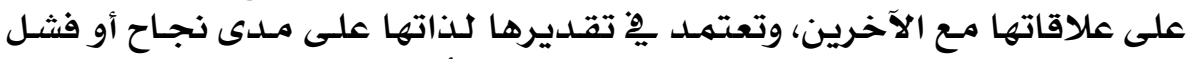

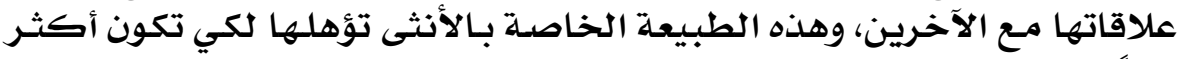

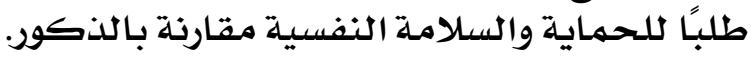

\section{مناقشة نتائج السؤال الخامس:}

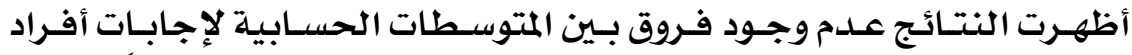

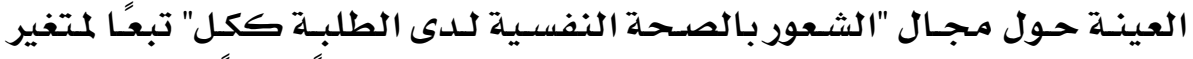

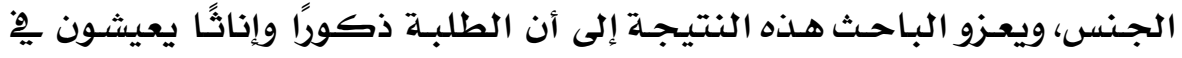

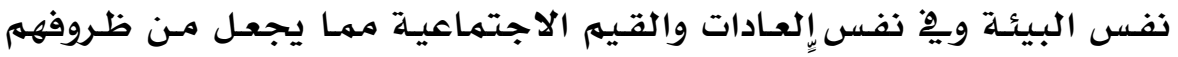

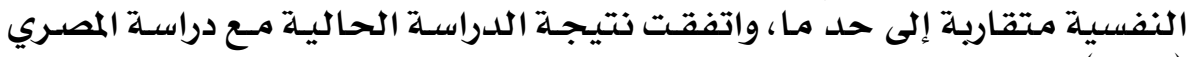

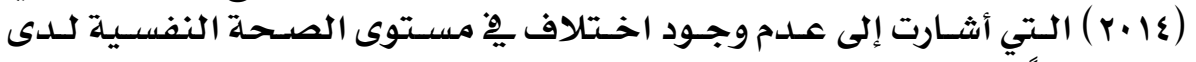

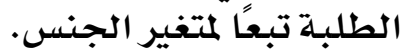

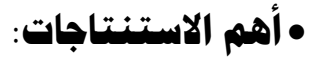

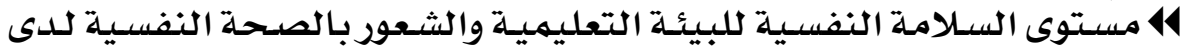

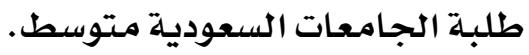

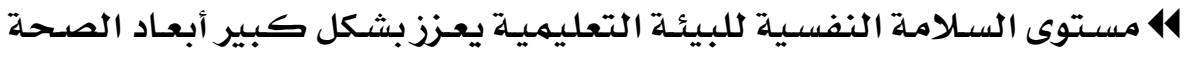
النفسية.

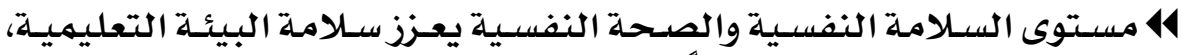

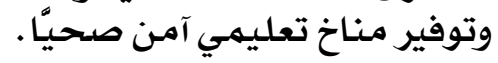

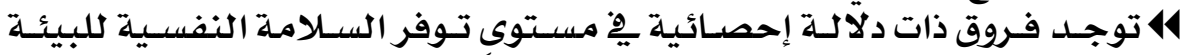

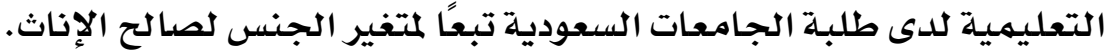

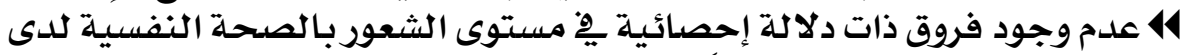

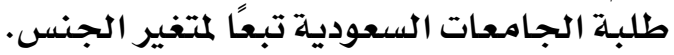

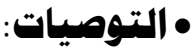

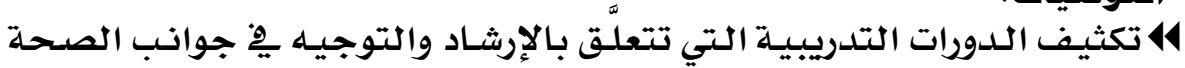

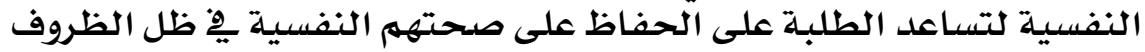




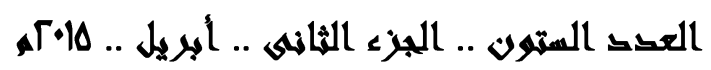

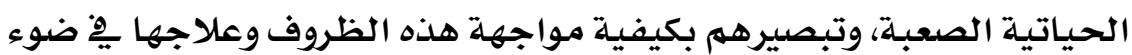

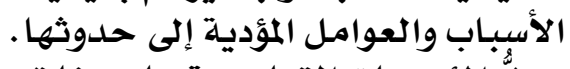

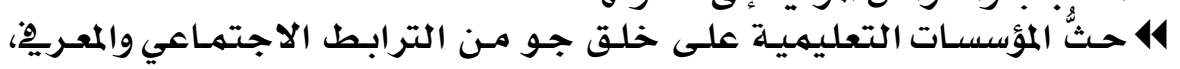

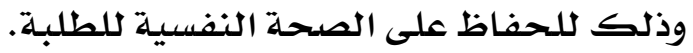

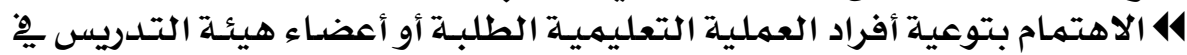

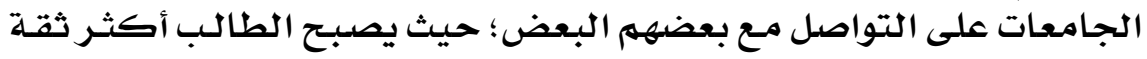

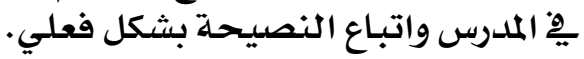

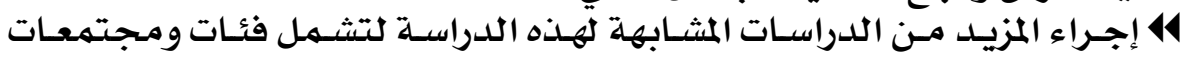

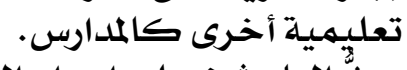

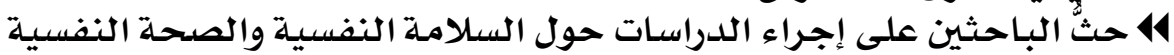

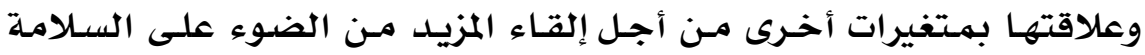

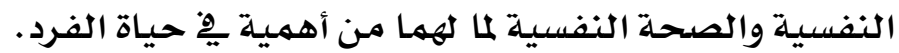

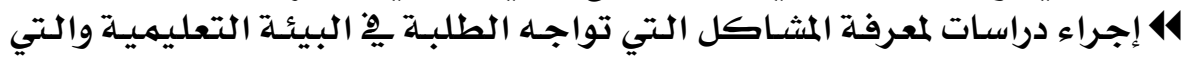

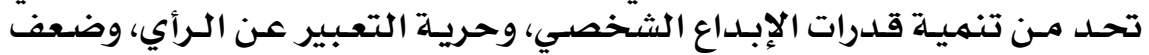

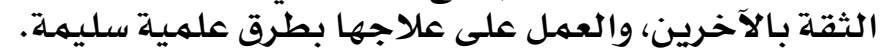

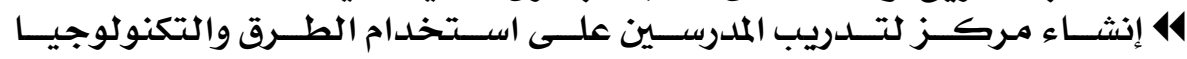

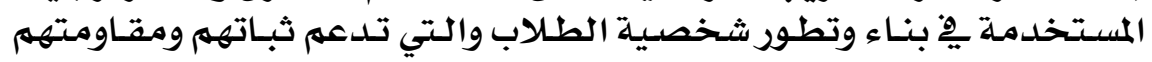
•أولا: المراجع المؤثرات السلبية العربية.

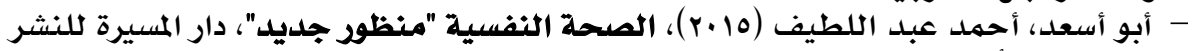
والتوزيع، الأردن.

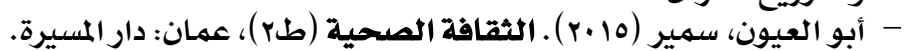

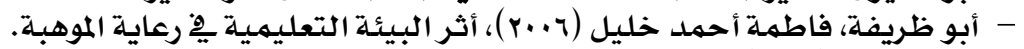

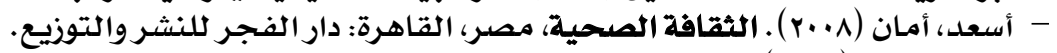

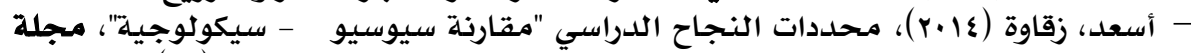

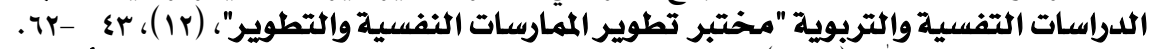

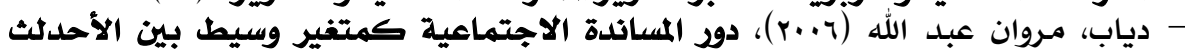

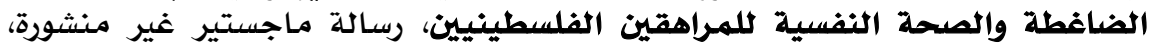

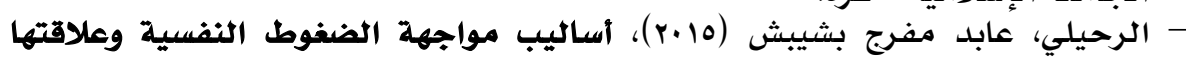

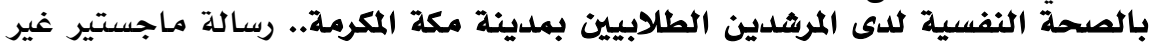

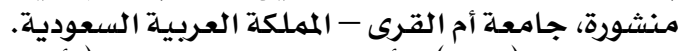

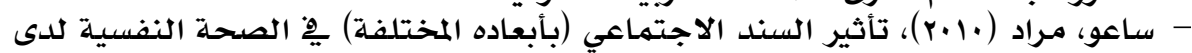

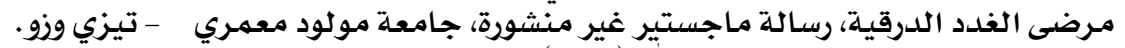

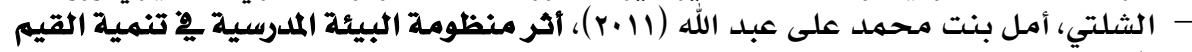

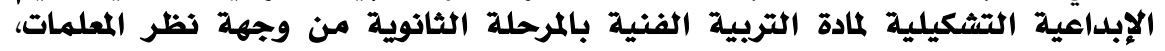

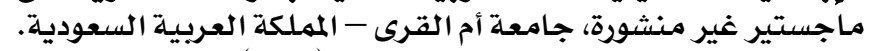

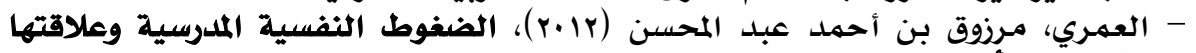

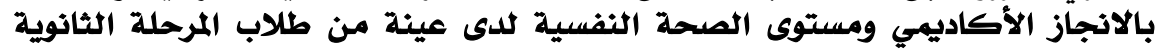




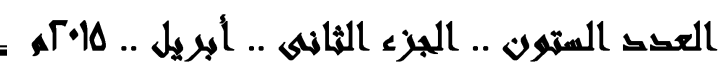

بمحافظة الليث، رسالة ماجستير غير منشورة، جامعة أم القرى - المملكة العربية

السعوديـة.

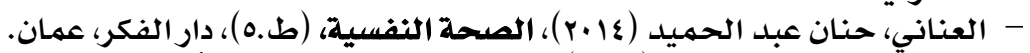

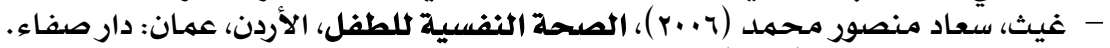

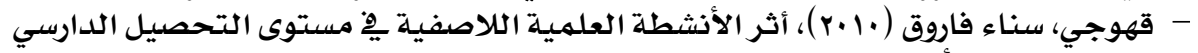

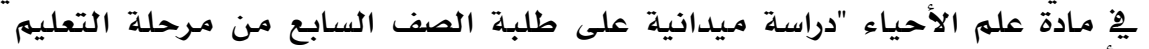

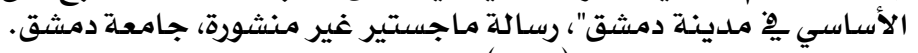

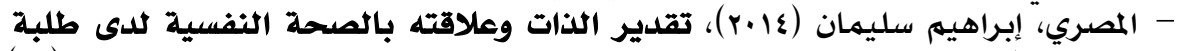

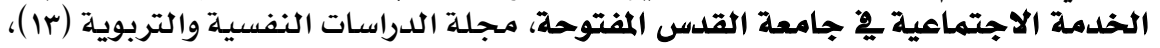
$.1 \leqslant 9-|\mu|$

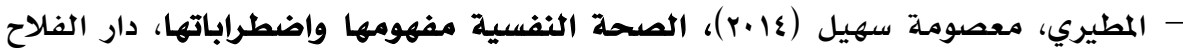

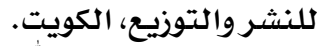

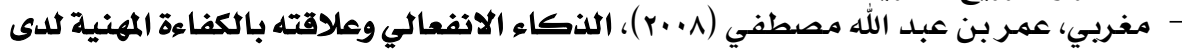

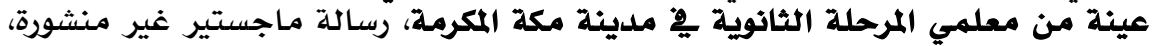
جامعة أم القرى، معلمي المملكة العربية المئورية السعودية.

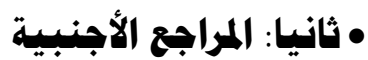
-Bacakova, M. (2011). Developing Inclusive Educational Practices for Refugee Children in the Czech Republic. Intercultural Education, 22(2), 163-175.

-Baeva, I., and Bordovskaia, N. (2015). The psychological safety of the educational environment and the psychological well-being of Russian secondary school pupils and teachers. Psychology in Russia: State of the Art, 8(1), 86-99

-Chukwuemeka, O. (2013). Environmental Influence on Academic Performance of Secondary School Students in Port Harcourt Local Government Area of Rivers State. Journal of Economics and Sustainable Development, 4(12), 34-39.

-Dollard, M., and Bakker, A. (2010). Psychosocial safety climate as a precursor to conducive work environments, psychological health problems, and employee engagement. Journal of Occupational and Organizational Psychology, 83, 579-599.

-Duruji, M, Azuh, D., and Olarenwaju, F. (2014) Learning Environment and Academic Performance Of Secondary School Students In External Examinations: A Study Of Selected Schools In Ota .International Conference on Education and New Learning Technologies EDULEARN14 Proceedings, 5042-5053.

- Egunsola, A. O. E. (2014). Influence of Home Environment on academic Performance of Secondary School Students in Agricultural Science in Adamawa State Nigeria. IOSR Journal of Research \& Method in Education (IOSR-JRME), 4(4), 46-53. 


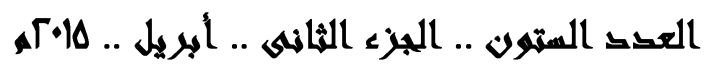

-Fisher, J. (2011). The Four Domains Model: Connecting Spirituality, Health and Well-Being. Religions 2(7), 17-29.

-George, U., Thomson, M., Chaze, F., and Guruge, S. (2015). Immigrant Mental Health, A Public Health Issue: Looking Back and Moving Forward. International Journal of Environmental Research and Public Health, 12, 13624-13648.

-Joshi, Sh., and Kumari, Sh. (2011). Religious Beliefs and Mental Health: An Empirical Review. DELHI PSYCHIATRY JOURNAL, 14(1), 40-51.

-Kislyakov, P, Shmeleva, E, Karaseva.(2014). Monitoring of Education Environment according to the Social-Psychological Safety Criterion, Published by Canadian Center of Science and Education

-Korir, D., and Kipkemboi, F. (2014). The Impact of School Environment and Peer Influences on Students' Academic Performance in Vihiga County, Kenya. International Journal of Humanities and Social Science, 4(5:1), 240-251.

-Kovrov, V., and Antonova, A. (2013). Safety of educational environment: psychological and pedagogical aspects. Giornale Italiano Della Ricerca Educativa, 10(10), 107-114.

-Major, B., Appelbaum, M. Beckman, L. Ann Dutton, M., Russo. N., West, C. (2009). Abortion and Mental Health " Evaluating the Evidence ". American Psychological Association, 64(9), 863-890

-Odeh. R., Oguche, O., and Ezekiel Dondo, L. (2015). Influence Of School Environment On Academic Achievement Of Students In Secondary Schools In Zone "A" Senatorial District Of Benue State, Nigeria. International Journal of Recent Scientific Researc, 6(7), 4914-4922.

- Ogbeba, J., and Muluku, A. (2013). Influence Of Clean School Environment and Standard Class Room Size and Facilities on Students' Achievement in Biology in Gwagwalada Area Council of Fct -Abuja. Case Studies Journal-Issue-Aug-2013 ISSN (2305509X), 21-26.

-Rah, Y. Shangmin, C. \& Thi, Thu (2009). Building Bridges Between Refugee Parents and Schools. International Journal of Leadership in Education, 12(4), 347-365.

-Rivers, I., Poteat, V., Noret, N., and Ashurst, N. (2011). Observing Bullying at School: The Mental Health Implications Witness Status. School Psychology Quarterly (American Psychological Association), 24(4), 211-223. 


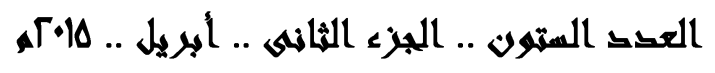

-Santos, S., Soares, M., and Pestana Hirata, A. (2013). Attitudes, knowledge, and opinions regarding mental health among undergraduate nursing students. Rev Esc Enferm USP, 47(5), 11951202

-Thabet, Abdel Aziz: Abed, Yehia: Vostanis, Panos (2004). Comorbidity of PTSD and depression among refugee children during war conflict. Journal of Child Psychology and Psychiatry, 45(3), 53-542.

-Verrocchio, M., Ambrosini, A., and Fulcheri, M. (2013). Promotion of mental health in children of parents with a mental disorder. Ann Ist Super Sanità, 49(4), 406-411.

-Wheeler, A., McKenna, B., Madell, D., Harrison, J., Prebble, K., Larsson, E., Dunbar, L., and Nakarada-Kordic, I. (2015). Selfreported health-related quality of life of mental health service users with serious mental illness in New Zealand. J OURNAL OF PRIMARY HEALTH CARE , 7(2), 117-123

-Volkova, E. N. (Ed.). (2011). Nasilie i shestokoe obrashenie s detmi: Istochniki, prichinyi, posledstviya, rezheniya [Violence and abuse of children: Sources, causes, effects, solutions]. St. Petersburg: Knizhnyiy Dom.

-Bordovskaia, N. V. (2012). Vozmozhnosti obrazovatelnoi sredyi v professionalno-lichnostnom pazvitie studentov [Opportunities in the educational environment for students' professional and personal development]. In Professionalno-lichnostnoe razvitie buduschego spetsialista [The professional and personal development of the future professional] (pp. 76-91). St. Petersburg: SPbGU. 